\title{
Biological and Chemical Diversity of Marine Sponge-Derived Microorganisms over the Last Two Decades from 1998 to 2017
}

\author{
Mei-Mei Cheng ${ }^{1,2,+}$, Xu-Li Tang ${ }^{3,+}$, Yan-Ting Sun ${ }^{1,2}$, Dong-Yang Song ${ }^{1,2}$, Yu-Jing Cheng ${ }^{1,2}$, \\ Hui Liu ${ }^{1,2}$, Ping-Lin $\mathrm{Li}^{1,2, *}$ and Guo-Qiang $\mathrm{Li}^{1,2, *(D)}$ \\ 1 Key Laboratory of Marine Drugs, Chinese Ministry of Education, School of Medicine and Pharmacy, Ocean \\ University of China, Yushan Road 5, Qingdao 266003, China; alisa_0701@126.com (M.-M.C.); \\ syt@stu.ouc.edu.cn (Y.-T.S.); 21170831098@stu.ouc.edu.cn (D.-Y.S.); c17860731575@163.com (Y.-J.C.); \\ LH1498740241@163.com (H.L.) \\ 2 Laboratory of Marine Drugs and Biological Products, National Laboratory for Marine Science and \\ Technology, Qingdao 266235, China \\ 3 College of Chemistry and Chemical Engineering, Ocean University of China, Songling Road 238, \\ Qingdao 266100, China; tangxuli@ouc.edu.cn \\ * Correspondence: lipinglin@ouc.edu.cn (P.-L.L.); liguoqiang@ouc.edu.cn (G.-Q.L.); \\ Tel.: +86-532-8203-2323 (P.-L.L.); +86-532-8203-3054 (G.-Q.L.) \\ + These authors contributed equally to this work.
}

Academic Editor: Jetze J. Tepe

Received: 13 January 2020; Accepted: 10 February 2020; Published: 14 February 2020

\begin{abstract}
Marine sponges are well known as rich sources of biologically natural products. Growing evidence indicates that sponges harbor a wealth of microorganisms in their bodies, which are likely to be the true producers of bioactive secondary metabolites. In order to promote the study of natural product chemistry and explore the relationship between microorganisms and their sponge hosts, in this review, we give a comprehensive overview of the structures, sources, and activities of the 774 new marine natural products from sponge-derived microorganisms described over the last two decades from 1998 to 2017.
\end{abstract}

Keywords: marine sponges; sponge-derived microorganisms; natural products; relationship

\section{Introduction}

The term "symbiosis" was first defined by the German mycologist Heinrich Anton de Bary in 1879 as "the living together of unlike organisms" [1]. Symbiosis is an intimate and long-term biological interaction between two different biological organisms, whether reciprocal, symbiotic, or parasitic. It is abundant and widespread in the sea for symbioses between microorganisms and marine organisms. Most marine animals and plants such as sponges, corals, sea squirts, worms, and algae host contain diverse and abundant symbiotic microorganisms. Among them, sponge is the most primitive type of metazoan, which has been used as an important source of marine active compounds. There are many types of sponges (between 10,000 and 15,000 species), accounting for $6.7 \%$ of all marine animal species. At present, detected sponges can be divided into four classes: Calcarea (about 400 species), Hexactinellida (about 600 species), Demospongiae (about 4000 species), and Homoscleromorpha (about 15 species). Sponges are multicellular filter feeders, in which a layer of flagellum cells arranged in the body cavity of the sponge provides nutrients and oxygen to the spongy body through the generated water flow. Its unique pore structure makes it an excellent host for many marine microorganisms, which account for a large amount of sponge biomass. Some studies have shown that the true source of secondary metabolites in sponges may be their symbiotic microbes. Therefore, a comprehensive 
review of the existing studies of the sponge-associated microbes is expected to reveal the potential chemical association between symbiotic microbes and their hosts.

In recent years, research on co-existing microorganisms derived from marine animals and plants has received increasing attention, especially sponge symbiotic microorganisms. Several reviews discussing "sponge-derived microorganisms" have been published, and the topics include genetics [2], ecology [3,4], and chemical diversity [5-7]. In 2014, Cristian et al. [8] reviewed the microbial community and its biological activity of the Irciniidae sponges, and discussed the relationship between the host and its co-existing microorganisms in combination with genetics and ecology. In 2017, Fehmida Bibi et al. [9] reviewed the latest studies on active secondary metabolites produced by sponge-derived commensal bacteria, suggesting that sponge symbiotic bacteria are one of the important sources of new drugs. Therefore, it is essential that a systematic overview for the chemical diversity especially for the new compounds of sponge-derived microorganisms were summarized.

In 1988, Stierle et al. in Montana State University in the United States obtained three diketopiperazine alkaloids-cyclo-(Ala-Pro), cyclo-(Val-Pro), and cyclo-(Leu-Pro)—from the sponge Tedania ignis-derived bacteria Micrococcus sp., which is the first natural product molecule obtained from the sponge symbiotic bacteria [10]. In the following 10 years, there have been several reports on secondary metabolites of sponge-derived microorganisms, most of which are about fungi, bacteria, and actinomycetes. The rapid development of this research is mainly after 1998. This review comprehensively focuses on the chemical diversity and biological activity of the symbiotic microorganisms derived from different sponge species, covering 774 new compounds totally from 1998 to 2017.

\section{Sponges and Derived Microbes' Chemical Diversity}

\subsection{Class Calcarea}

Two new compounds, designated JBIR 74-75 (1-2) (Figure 1), were isolated from the fungus Aspergillus sp. fS14, which was isolated from the unidentified marine sponge (class, Calcarea) collected off Ishigaki Island, Okinawa, Japan. Neither of the two compounds showed cytotoxic activity against several cancer cell lines $\left(\mathrm{IC}_{50}>100 \mu \mathrm{M}\right)$, nor did they show antimicrobial activity against Candida albicans, Micrococcus luteus, and Escherichia coli [11].

\subsubsection{Order Baerida}

Family Baeriidae

From a bacterium Microbulbifer sp. strain L4-n2 associated with the sponge Leuconia nivea, eight new natural parabens 3-10 (Figure 1) were isolated. Compounds 3, 4, 5, and 9 appeared for the first time as natural products. Compound 5 exhibited the greatest efficiency against $S$. aureus with minimal inhibitory concentration (MIC) values of 2.8-5.6 $\mu \mathrm{M}$ [12].

\subsubsection{Order Clathrinida}

\section{Family Clathrinidae}

Fractionation of the strain Micromonospora sp. (strain L-31-CLCO-002) from the sponge Clathrina coriacea collected off Sanish Fuerteventura Island afforded two new indolocarbazole alkaloids 11-12 (Figure 1), and it exhibited stronger cytotoxic activities against the P388D1, A549, HT-29, and SK-MEL-28 cell lines with $\mathrm{IC}_{50}$ values of $2-40 \mathrm{nM}$ [13]. 


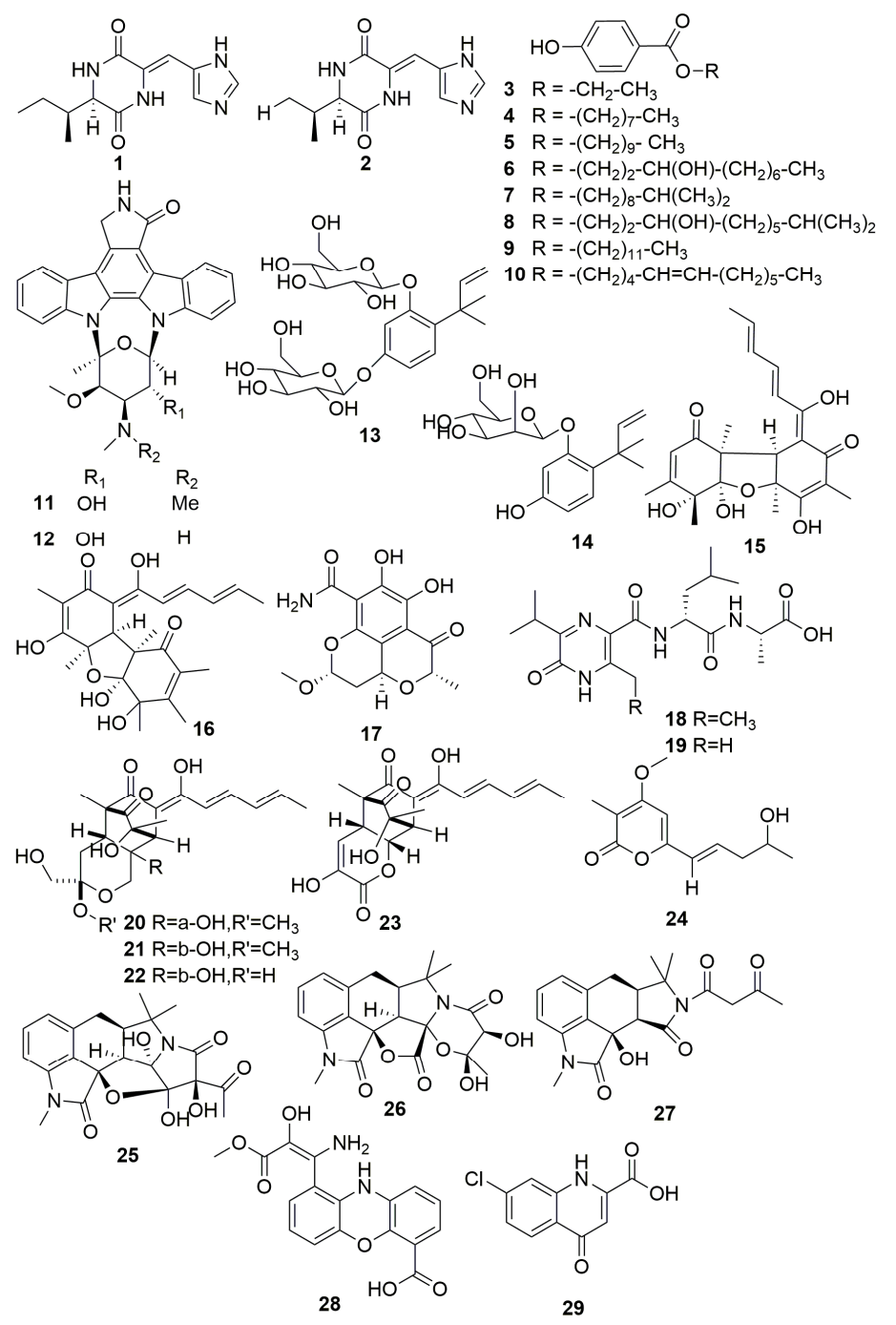

Figure 1. Structures of compounds 1-29.

\subsection{Class Demospongiae}

Chemical investigation of a fungus Acremonium sp. SpF080624G1f 01 from a Demospongiae sponge (Ishigaki Island, Okinawa, Japan) led to the isolation of two novel glycosyl benzendiols, JBIR 37-38 (13-14) (Figure 1) [14]. From the fungus Penicillium citrinum SpI080624G1f 01, a new compound termed JBIR-59 (15) and new sorbicillinoid derivative designated as JBIR-124 (16) (Figure 1) were isolated. Compound 15 showed reduced L-glutamate toxicity in N18-RE-105 cells with EC 50 values of $71 \mu \mathrm{M}$, and compound 16 had DPPH radical scavenging activity $\left(\mathrm{IC}_{50}, 30 \mu \mathrm{M}\right)[15,16]$. A new salicylamide derivative termed JBIR-58 (17) [17] and two new pyrazinones JBIR 56-57 (18-19) (Figure 1) [18] were isolated from actinomyces Streptomyces SpD081030ME-02 and SpD081030SC-03, which originated in Demospongiae sponges, respectively. Compound 17 exhibited a weak cytotoxic effect on human cervical carcinoma (HeLa) cells $\left(\mathrm{IC}_{50}, 28 \mu \mathrm{M}\right)$. 


\subsubsection{Order Agelasida}

Family Agelasidae

From a strain of fungus Trichoderma sp. derived from the Caribbean sponge Agelas dispar, four novel sorbicillinoid polyketide derivatives (20-23) (Figure 1) were isolated; unfortunately, the tested compounds 20-23 showed no bioactivities [19]. A new pyranone derivative, trichopyrone (24) (Figure 1), was isolated from the fungus Trichoderma viride, which was originally separated from the Caribbean sponge Agelas dispar and shown to have very weak or no effects in a series of bioassays (radical scavenging, antioxidant, antimicrobial, inhibition of HIV-1 RT) [20]. Two new highly oxygenated hexacyclic cyclopiazonic acid (CPA), speradines B-C (25-26), together with one new related tetracyclic oxindole alkaloid, speradine D (27) (Figure 1), were produced in the fungal strain Aspergillus flavus MXH-X104 associated with the marine sponge Agelas aff. nemoechinata collected from the Xisha Islands of China. However, their bioassay was disappointing [21]. A sponge-associated actinomycetes Streptomyces sp. SBT345 from the Mediterranean sponge Agelas oroides provided a new cytotoxic phenoxazin analogue strepoxazine A (28) and a new antioxidant and antichlamydial quinolone ageloline A (29) (Figure 1). Compounds 28 and 29 exhibited cytotoxic activity against leukaemia cells HL-60 cells with an $\mathrm{IC}_{50}$ value of $8 \mu \mathrm{g} / \mathrm{mL}$ and inhibitory activity toward the formation and growth of Chlamydia trachomatis inclusion in a dose-dependent manner with an $\mathrm{IC}_{50}$ value of $9.54 \pm 0.36 \mu \mathrm{M}[22,23]$, respectively.

\subsubsection{Order Axinellida}

From a strain of the fungus Trichoderma atroviride (NF16) derived from an Axinellid sponge collected from the Mediterranean Sea, eight new linear peptaibols (30-37) (Table 1) were isolated and found to have antimicrobial activity against environmental bacteria isolated from the Mediterranean coast of Israel [24].

Table 1. Peptaibols (30-37) isolated from Trichoderma atroviride (NF16). Positions marked in gray differ between compounds.

\begin{tabular}{ccccccccc}
\hline Title & $\mathbf{3 0}$ & $\mathbf{3 1}$ & $\mathbf{3 2}$ & $\mathbf{3 3}$ & $\mathbf{3 4}$ & $\mathbf{3 5}$ & $\mathbf{3 6}$ & $\mathbf{3 7}$ \\
\hline 1 & AcAib & AcAib & AcAib & AcAib & AcAib & AcAib & AcAib & AcAib \\
2 & Ala & Ala & Ala & Ala & Ala & Ala & Ala & Ala \\
3 & Ala & Ala & Ala & Ala & Ala & Ala & Ala & Ala \\
4 & Aib & Aib & Aib & Aib & Aib & Aib & Aib & Aib \\
5 & Iva & Aib & Aib & Aib & Iva & Iva & Aib & Iva \\
6 & Gln & Gln & Gln & Gln & Gln & Gln & Gln & Gln \\
7 & Aib & Aib & Aib & Aib & Aib & Aib & Aib & Aib \\
8 & Aib & Aib & Aib & Aib & Aib & Aib & Aib & Aib \\
9 & Aib & Ala & Ala & Ala & Aib & Ala & Aib & Ala \\
10 & Ser & Ser & Ser & Ser & Ser & Ser & Ser & Ser \\
11 & Leu & Leu & Leu & Leu & Leu & Leu & Leu & Leu \\
12 & Aib & Aib & Aib & Aib & Aib & Aib & Aib & Aib \\
13 & Pro & Pro & Pro & Pro & Pro & Pro & Pro & Pro \\
14 & Leu & Leu & Val & Val & Val & Val & Leu & Val \\
15 & Aib & Aib & Aib & Aib & Aib & Aib & Aib & Aib \\
16 & Ile & Ile & Ile & Ile & Ile & Ile & Ile & Ile \\
17 & Glu & Gln & Gln & Glu-OMe & Glu-OMe & Glu-OMe & Glu-OMe & Gln \\
18 & Gln & Gln & Gln & Gln & Gln & Gln & Gln & Gln \\
19 & Pheol & Pheol & Pheol & Pheol & Pheol & Pheol & Pheol & Pheol \\
\hline
\end{tabular}

Family Axinellidae

Two unique steroids possessing the bicyclo [4.4.1] A/B ring system, isocyclocitrinol A (38) and 22-acetylisocyclocitrinol A (39) (Figure 2), were isolated from Penicillium citrinum colonizing in a sponge 
(Axinella sp.) collected in Papua New Guinea, showing weak antibacterial activity against Staphylococcus epidermidis and Enterococcus durans [25]. Seven new compounds, bicoumanigrin (40), aspernigrins A-B (41-42), and pyranonigrins A-D (43-46) (Figure 2) were obtained from the strain of Aspergillus nige, which is a symbiont on the Mediterranean sponge Axinella damicornis. Compound $\mathbf{4 0}$ showed moderate cytotoxicity against human cancer cell lines, and compound $\mathbf{4 2}$ displayed a strong neuroprotective effect against stimulation caused by L-glutamic acid or quisqualic acid [26]. Two new congeners communesins C-D (47-48) (Figure 2) were isolated from the fungus Penicillium sp., which was derived with the Mediterranean sponge Axinella verrucose. Both exhibited moderate antiproliferative activity against the different leukemia cell lines [27].

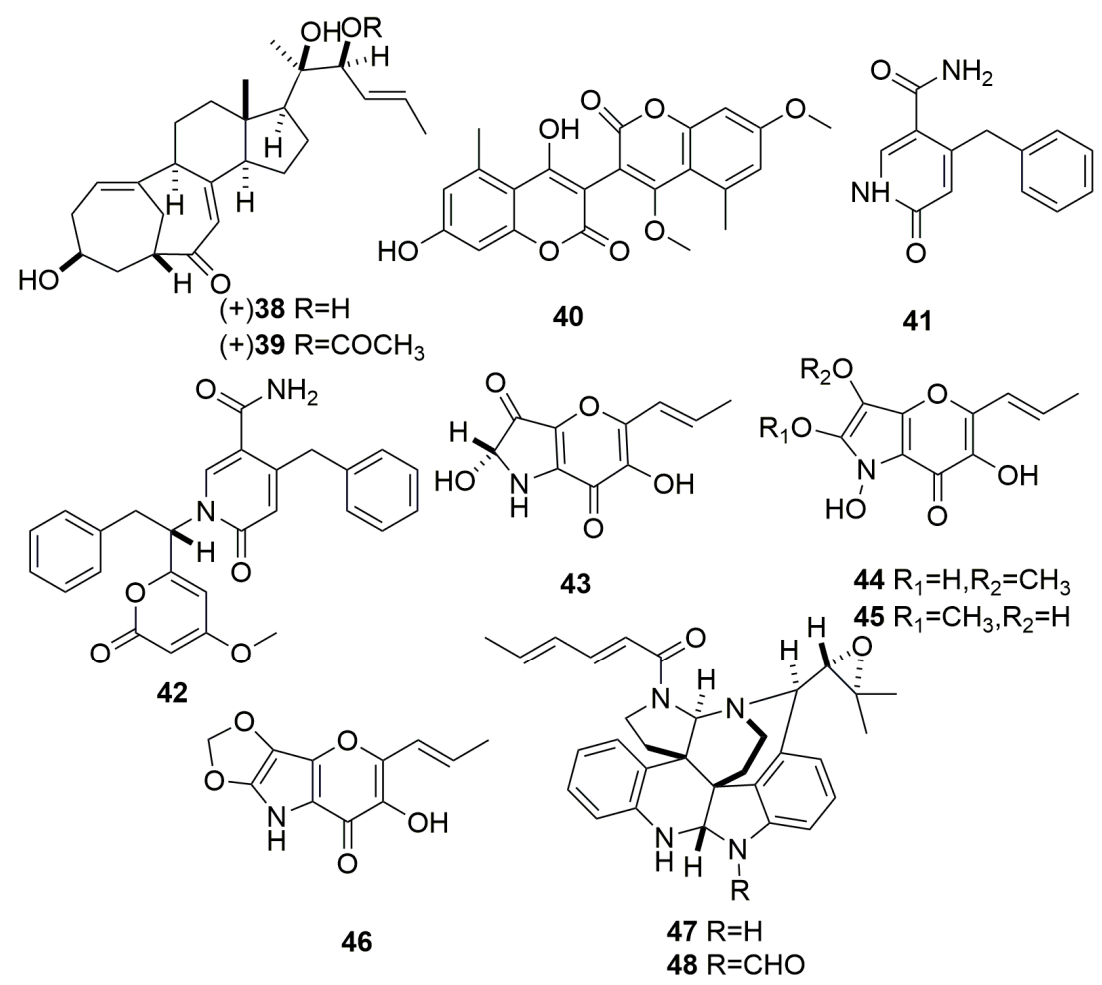

Figure 2. Chemical structures of new compounds 38-48.

Highly N-Methylated Linear Peptides, RHM 1-4 (49-50,53-54), as well as linear pentadecapeptides efrapeptin $\mathrm{E} \alpha$ (51) and efrapeptin H (52) (Figure 3), were produced by fungus Acremonium sp. (UCSC coll. no. $021172 \mathrm{cKZ}$ ), which is associated with the marine sponge Teichaxinella sp. (Papua New Guinea). Compound 51 displayed very strong cytotoxic activity with an $\mathrm{IC}_{50}$ value of $1.3 \mathrm{nM}$ against H125 cells [28,29]. Four new tetromycin derivatives, tetromycins 1-4 (55-58) (Figure 3), were produced by a strain actinomycete of Streptomyces axinellae Pol001T originally derived from the marine sponge Axinella polypoides (Banyuls-sur-Mer, France). All four compounds showed antiparasitic activities against Trypanosoma brucei and the time-dependent inhibition of cathepsin L-like proteases with Ki values in the low micromolar range [30]. Compound 59 (Figure 3) was isolated from a bacterium Pseudomonas fluorescens 4.9 .3 cultivated from the sponge Axinella damicornis (Turkey) [31]. 


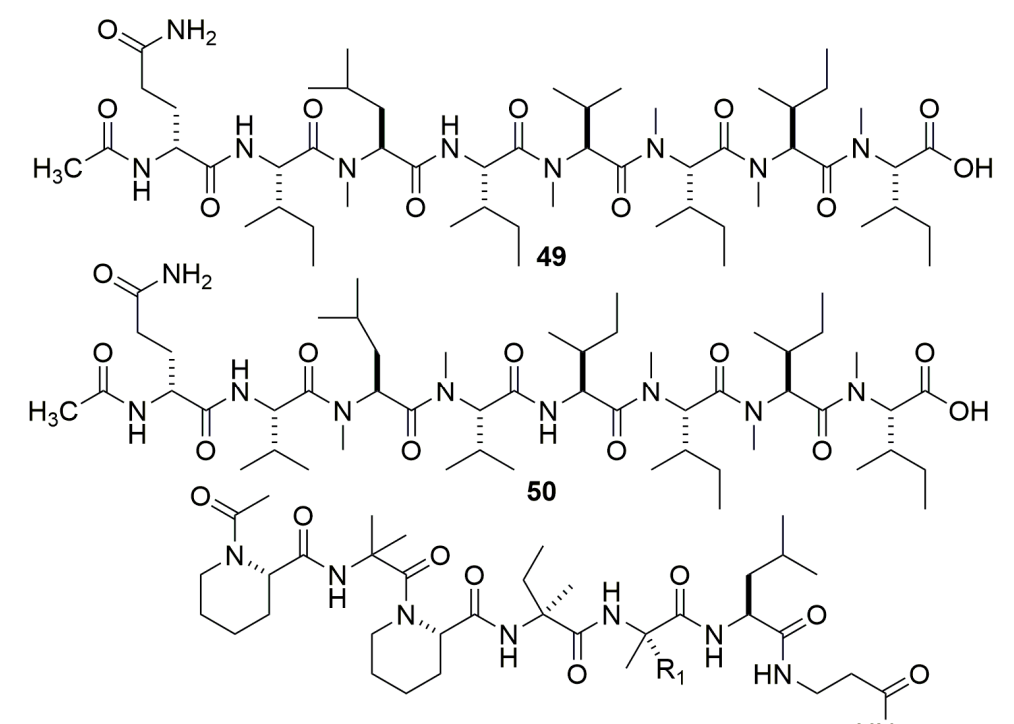

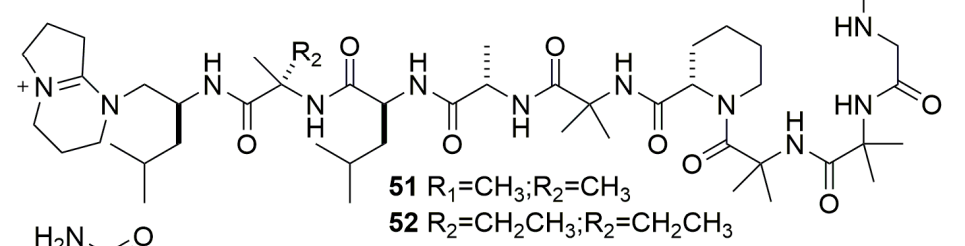

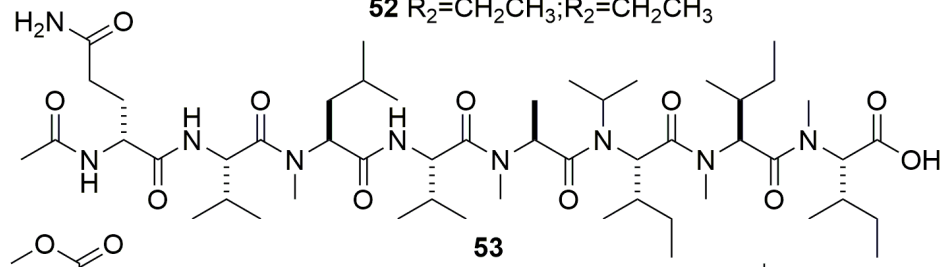<smiles>CCC(C)C(C(=O)N[C@H](CC)C(=O)N[C@@H](CC(C)C)C(=O)O)N(C)C(=O)[C@@H](NC(=O)[C@@H](CCC(=O)OC)NC(C)=O)C(C)CC</smiles>

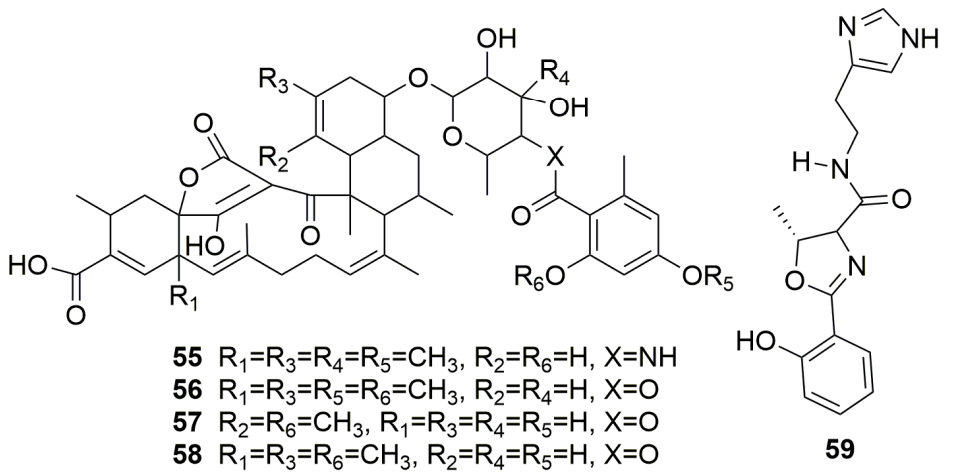

Figure 3. Chemical structures of diverse new molecules 49-59.

Two new oxaphenalenone dimers, talaromycesone A-B (60-61), and a new isopentenyl xanthenone, talaroxanthenone (62) (Figure 4), were found in the fungus Talaromyces sp. strain LF458 associated with the sponge Axinella verrucosa (Mediterranean Sea, Italy). Compound 60 exhibited potent antibacterial activity with an $\mathrm{IC}_{50}$ value of $3.70 \mu \mathrm{M}$ against human pathogenic Staphylococcus strains and an inhibitory activity of phosphodiesterase PDE-4B2 ( $\left.\mathrm{IC}_{50} 7.25 \mu \mathrm{M}\right)$. In addition, compound 60 and compound 62 also displayed potent acetylcholinesterase inhibitory activities with an $\mathrm{IC}_{50}$ of 7.49 and $1.61 \mu \mathrm{M}$, respectively [32]. The fungus Talaromyces rugulosus from the Mediterranean sponge Axinella cannabina (Turkey) provided three butenolides (63-65), seven (3S)-resorcylide derivatives 
(66-72), two butenolide-resorcylide conjugates (73-74), and two dihydroisocoumarins (75-76) (Figure 4). Compounds 73-74 exhibited potent cytotoxicity against the L5178Y murine lymphoma cell line with IC $_{50}$ values of 3.9 and $1.3 \mu \mathrm{M}$, respectively [33]. The chemical investigation of the mycelia and culture filtrate of Penicillium sp. DRF2 from the sponge Dragmacidon reticulatum (Brazil) yielded seven novel curvularins that belong to macrocyclic polyketides 12-Keto-10,11-dehydrocurvularin 77 and cis-10,11-Epoxycurvularin 78 and the sulfur-containing curvularin derivatives 79-83 (Figure 4) [34]. A study on fungus Hypocrea koningii PF04 derived from the sponge Phakellia fusca (Yongxing Island, China) afforded two new furan derivatives, hypofurans A-B (84-85), and three new cyclopentenone derivatives, hypocrenones A-C (86-88) (Figure 4). Compound 84 showed modest antibacterial activity against Staphylococcus aureus (MIC, $32 \mu \mathrm{g} / \mathrm{mL}$ ) and moderate (2,2-diphenyl-1-picrylhydrazyl) DPPH radical scavenging capacity $\left(\mathrm{IC}_{50}, 27.4 \mu \mathrm{g} / \mathrm{mL}\right)$ [35].

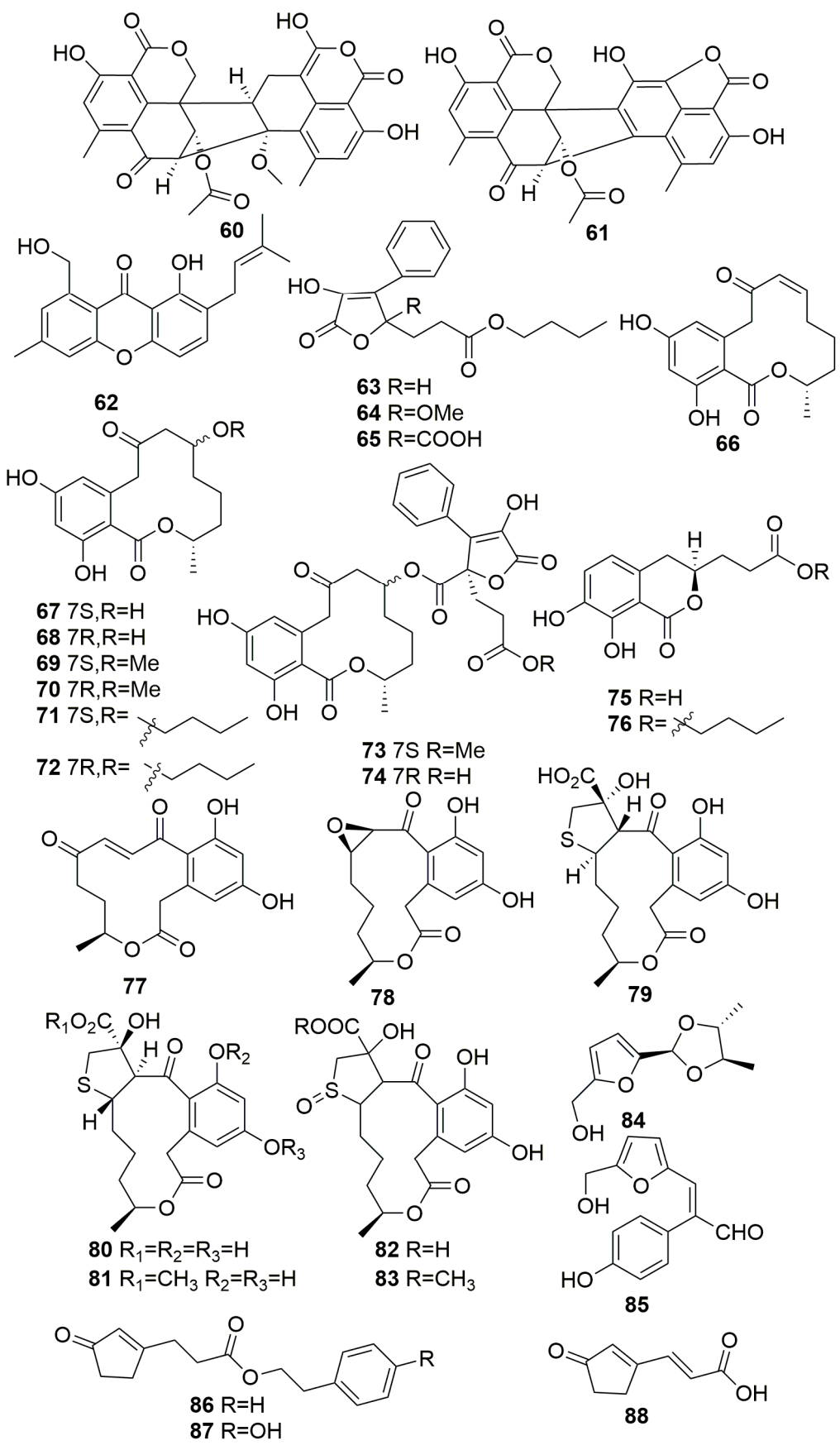

Figure 4. Chemical structures of diverse new molecules 60-88. 
From the fungus Arthrinium arundinis ZSDS1-F3 cultured from a Phakellia fusca marine sponge (Xisha Islands, China), four new cytochalasins, arthriniumnins A-D (89-92), a new natural product, ketocytochalasin (93), three new 4-hydroxy-2-pyridone alkaloids, arthpyrones A-C (94-96), and a new natural product, phenethyl 5-hydroxy-4-oxohexanoate (97) (Figure 5), were isolated. Compounds 94 and 96 displayed significant cytotoxicities against the selected tumor cell lines with $\mathrm{IC}_{50}$ values ranging from 0.24 to $45 \mu \mathrm{M}$. Furthermore, compound 96 displayed acetylcholinesterase (AchE) inhibitory activity with an $\mathrm{IC}_{50}$ value of $0.81 \mu \mathrm{M}$ [36-38]. Five unusual 14-membered macrolides, gliomasolides A-E (98-102) (Figure 5), were produced in fungus Gliomastix sp. ZSDS1-F7-2 from the marine sponge Phakellia fusca Thiele (South China Sea). Only compound 98 exhibited moderate inhibitory effect with an $\mathrm{IC}_{50}$ value of $10.1 \mu \mathrm{M}$ against the growth of HeLa cell lines [39]. Sponge-derived fungus Hypocrea koningii PF04 (from the sponge Phakellia fusca collected off Yongxing Island, China) resulted in one new tyrosol derivative, hypocrol A (103) (Figure 5) with weak antibacterial activity [40]. Three new cyclohexadepsipeptides, oryzamides A-C (104-106) (Figure 5) originated in fungus Nigrospora oryzae PF18 from the marine sponge Phakellia fusca (Yongxing Island, China) [41].

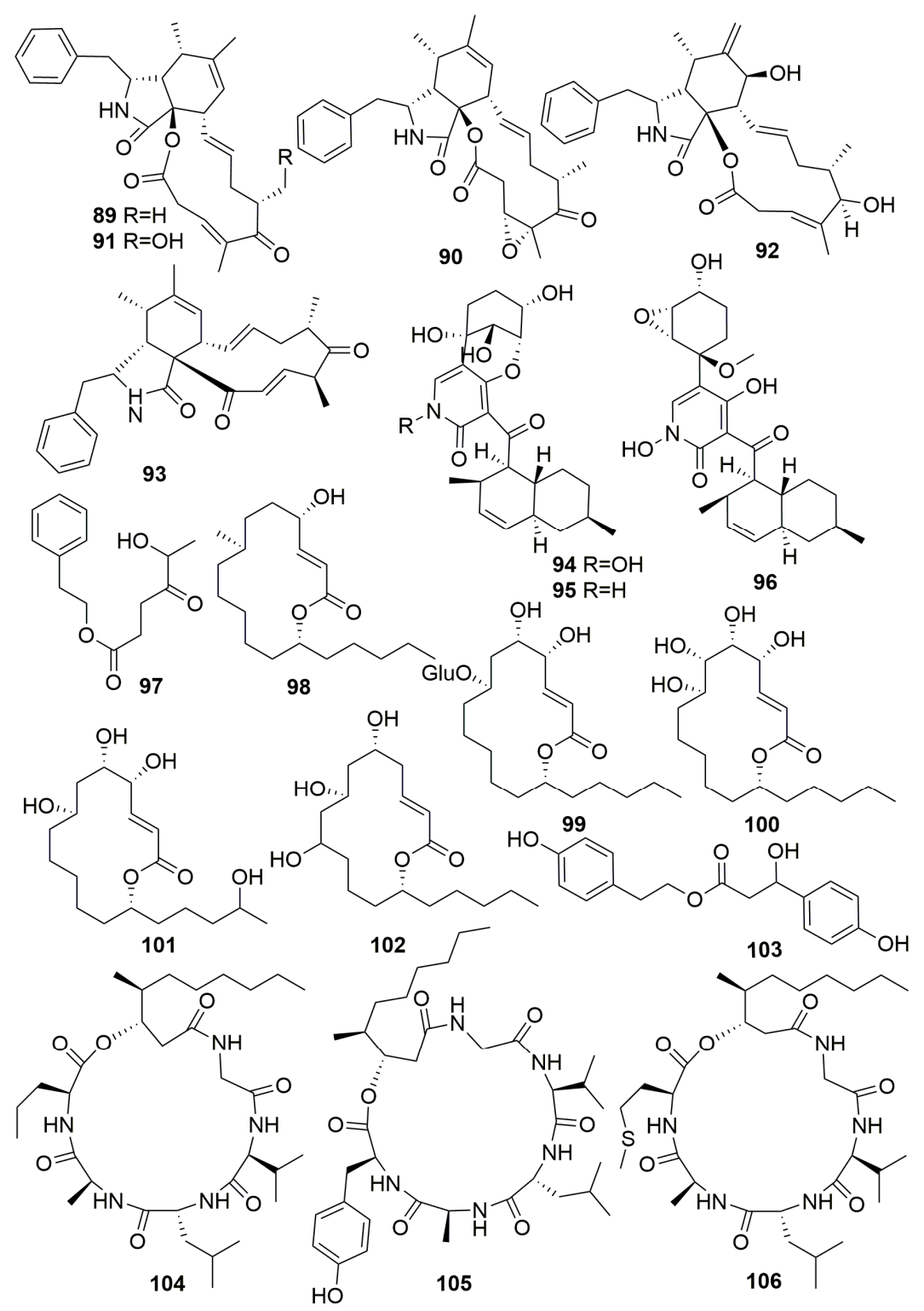

Figure 5. Chemical structures of compounds 89-106. 
Three racemates of diorcinol monoethers, ( \pm )-versiorcinols A-C (107-109), and 12 previously undescribed polyketide derivatives, heterocornols A-L (110-121) (Figure 6), were isolated from the fungus Aspergillus versicolor 16F-11 and Pestalotiopsis heterocornis XWS03F09 cultivated from the sponge Phakellia fusca (the Xisha Islands, China). The bioassays of all the compounds toward selected models were disappointing [42,43]. An examination of the fungus Pestalotiopsis heterocornis originated from the sponge Phakellia fusca (Xisha Islands of China) yielded two isocoumarins, pestaloisocoumarins A-B (122-123), one sesquiterpenoid degradation, isopolisin B (124), and one furan derivative, pestalotiol A (125) (Figure 6) [44].

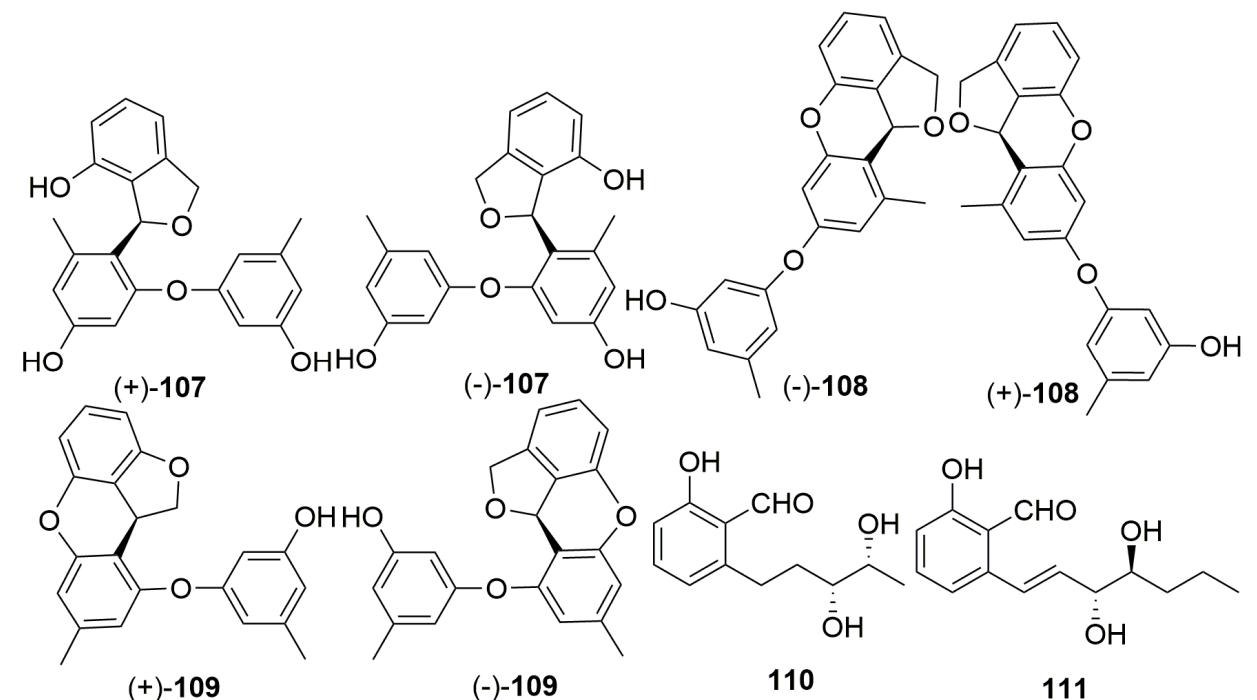

$(+)-109$

$(-)-109$

110

11<smiles>C=Cc1cccc(O)c1C(=O)OCC(C)O</smiles>

112

113

$115 \mathrm{O}$

116<smiles>O=C1C=Cc2cccc(O)c2CO1</smiles><smiles>CC=CC(C)[C@H](O)C=Cc1cccc(O)c1C=O</smiles><smiles>C/C=C\Cc1c(C=O)cccc1CC[C@H](O)[C@@H](C)O</smiles>

117

121

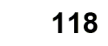

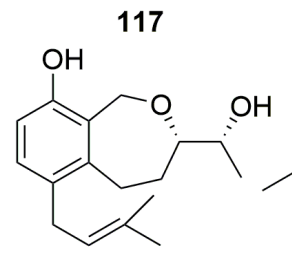<smiles>Cc1ccc2c(c1O)C(=O)OC[C@H]2O</smiles>

122<smiles>CCOC(=O)OCc1ccc(CO)c(C)c1O</smiles>
119

Figure 6. Chemical structures of new marine natural products 107-125.

Family Raspailiidae

Two new prenylated polyketides, epoxyphomalin A-B (126-127) (Figure 7), produced in fungus Phoma sp. derived from sponge Ectyplasia ferox (Caribbean Sea, Dominica) showed superior cytotoxicity at nanomolar concentrations toward 36 human tumor cell lines [45]. 


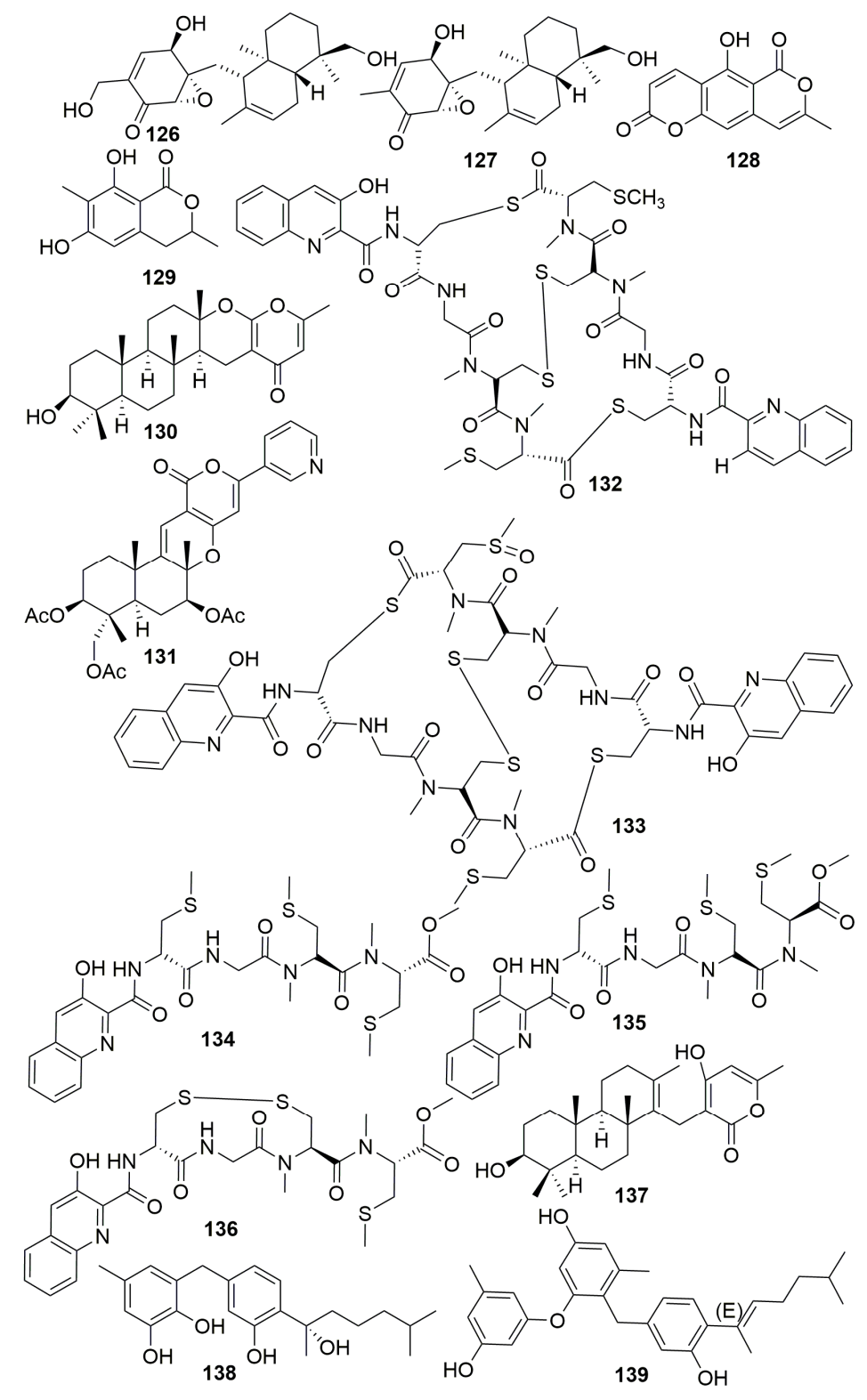

Figure 7. Chemical structures of compounds 126-139 derived from sponge-associated microbes.

\subsubsection{Order Biemnida}

\section{Family Rhabderemiidae}

A study on the fungus Aspergillus similanensis KUFA 0013 isolated from the sponge Rhabderemia sp. (Thailand) resulted in two new isocoumarin derivatives (128-129), a new chevalone derivative chevalone E (130), and a new natural product pyripyropene S (131) (Figure 7). Compound 130 was found to have synergism with the antibiotic oxacillin against methicillin-resistant Staphylococcus aureus (MRSA) [46].

\subsubsection{Order Chondrillida}

\section{Family Chondrillidae}

Five new analogs of thiocoraline (132-136) (Figure 7) were isolated from marine Verrucosispora sp. isolated from sponge Chondrilla caribensis $f$. caribensis (the Florida Keys). Compounds 132, 135, and 
136 demonstrated significant cytotoxicity against the $\mathrm{A} 549$ human cancer cell line with $\mathrm{IC}_{50}$ values of $0.13,2.86$, and $1.26 \mu \mathrm{M}$, respectively [47]. A new meroditerpene, sartorypyrone C (137) (Figure 7), was produced in the marine sponge-associated fungus Neosartorya paulistensis strain KUFC 7897 from sponge Chondrilla australiensis (Thailand) [48]. A chemical examination of the marine fungus Aspergillus sp. isolated from the sponge Chondrilla nucula (Turkey) yielded two new phenolic bisabolane sesquiterpenes, asperchondols A-B (138-139) (Figure 7). The antibacterial activities of compounds 138 and 139 were evaluated against eight human pathogenic bacteria [49].

\subsubsection{Order Chondrosiida}

\section{Family Chondrosiidae}

Seven new polyketides with linear pentaene fragments (140-146) (Figure 8) were characterized from the fungus Penicillium rugulosum associated with the sponge Chondrosia reniformis (Elba, Italy) [50].

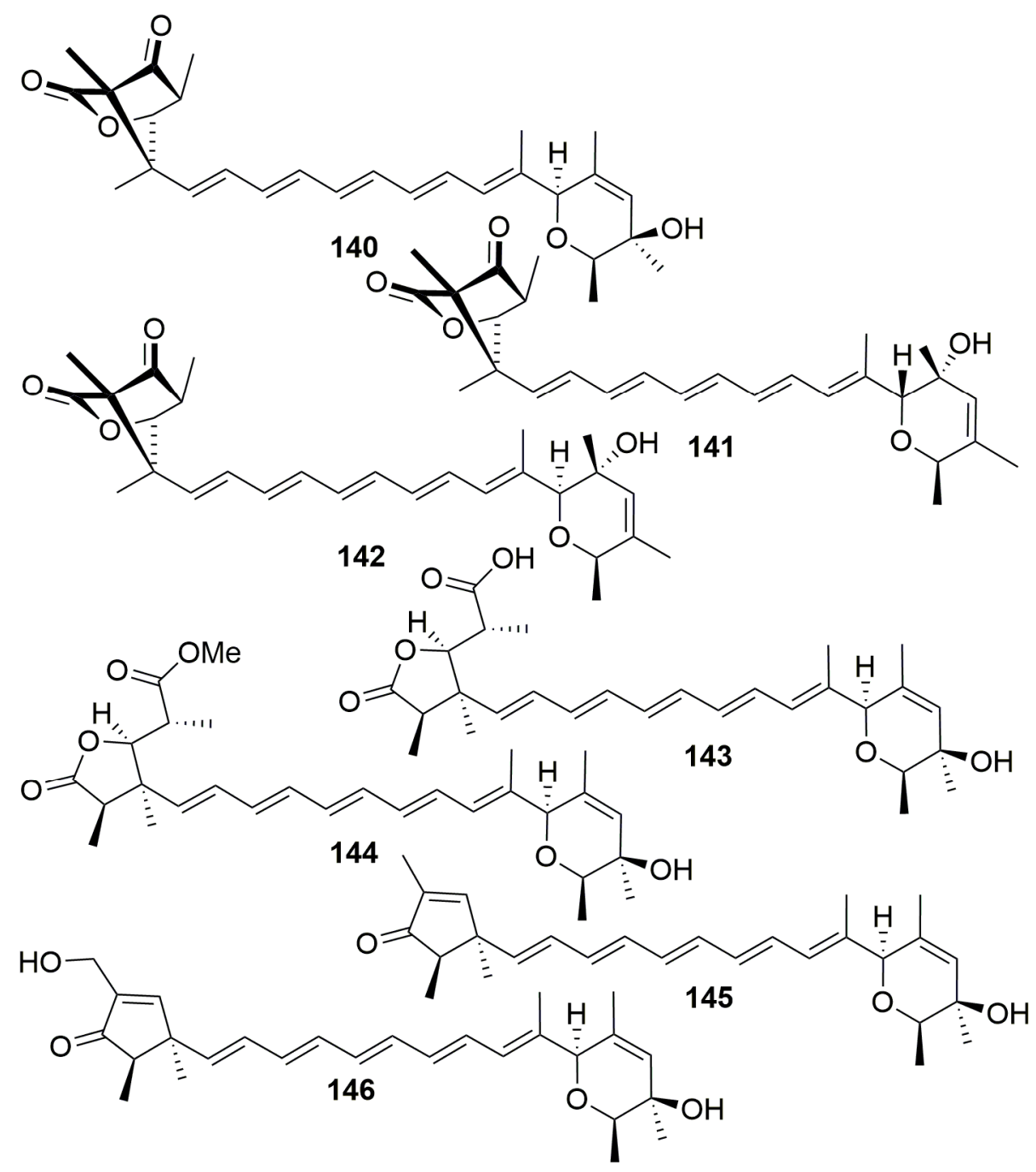

Figure 8. Chemical structures of seven new polyketides 140-146.

\subsubsection{Order Clionaida}

Family Clionaidae

A new compound, namely butylrolactone-VI (147) (Figure 9), was metabolized by the fungus Aspergillus sp. (2P-22) associated with the marine sponge Cliona chilensis (collected in the Pacific Sea, 
Chile), and its antibacterial and antitumor activities were determined [51]. A unique $O$-glycosylated disubstituted Microluside A (148) (Figure 9) was isolated from Micrococcus sp. EG45 associated with the Red Sea sponge Spheciospongia vagabunda, which exhibited antibacterial potential against Enterococcus faecalis JH212 and Staphylococcus aureus NCTC 8325 with MIC values of 10 and $13 \mu \mathrm{M}$, respectively [52]. From the actinomycete Actinokineospora sp. EG49 cultivated in Red Sea sponge Spheciospongia vagabunda, eight new benzanthraquinone-like $O$-glycosylated angucyclines, actinosporin A-H (149-156) (Figure 9), were isolated. Compounds 151 and 152 showed antioxidant potential using two different approaches including cell-free and cell-based assays [53-55].

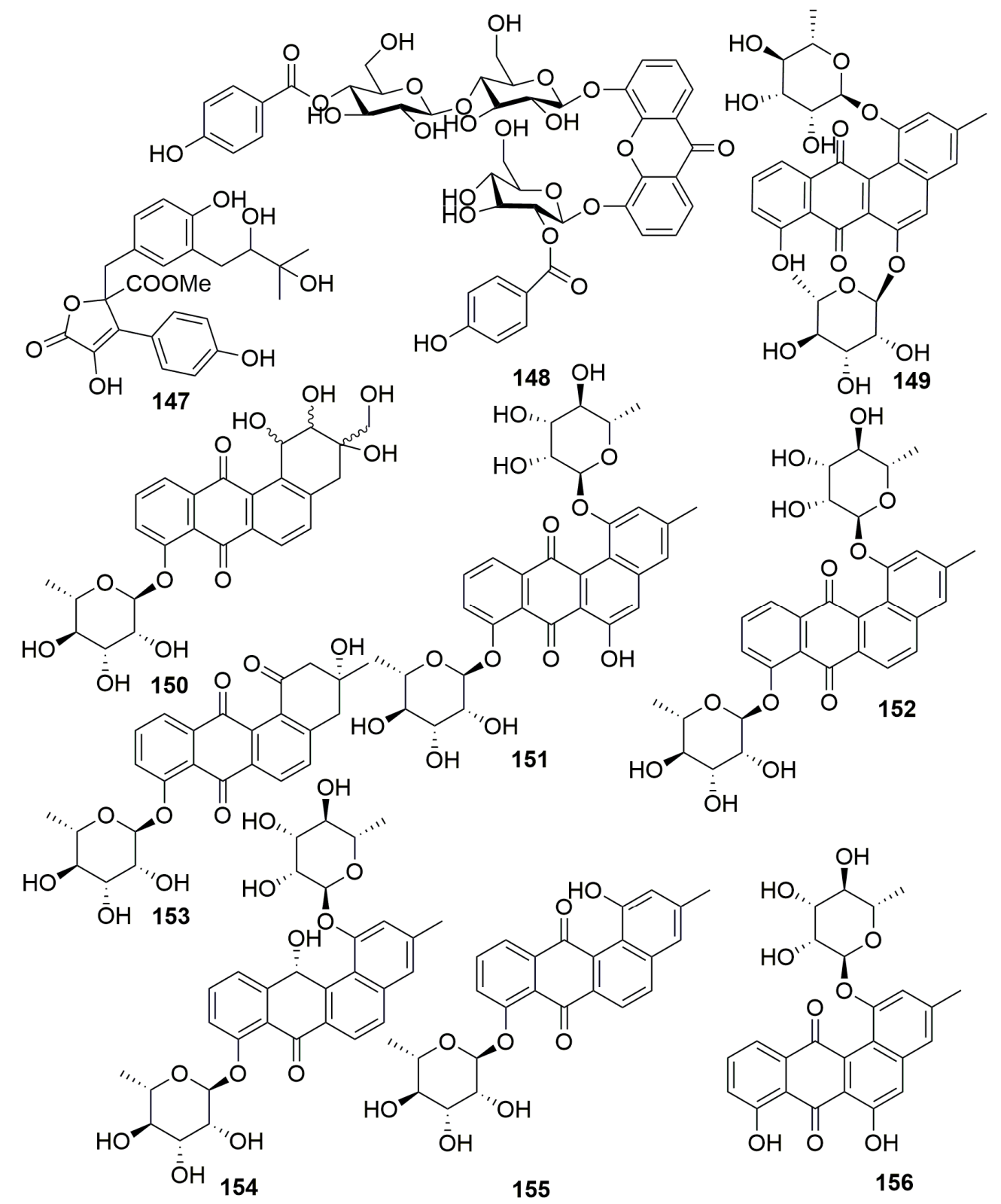

Figure 9. Chemical structures of new marine natural products 147-156.

\subsubsection{Order Dictyoceratida}

Three new benzolactone metabolites, chrysoarticulins A-C (157-159) (Figure 10), were produced in the fungus Chrysosporium articulatum obtained from an unidentified dictyoceratid sponge (Korea). The tested bioactivity for them was unfavorable [56]. 


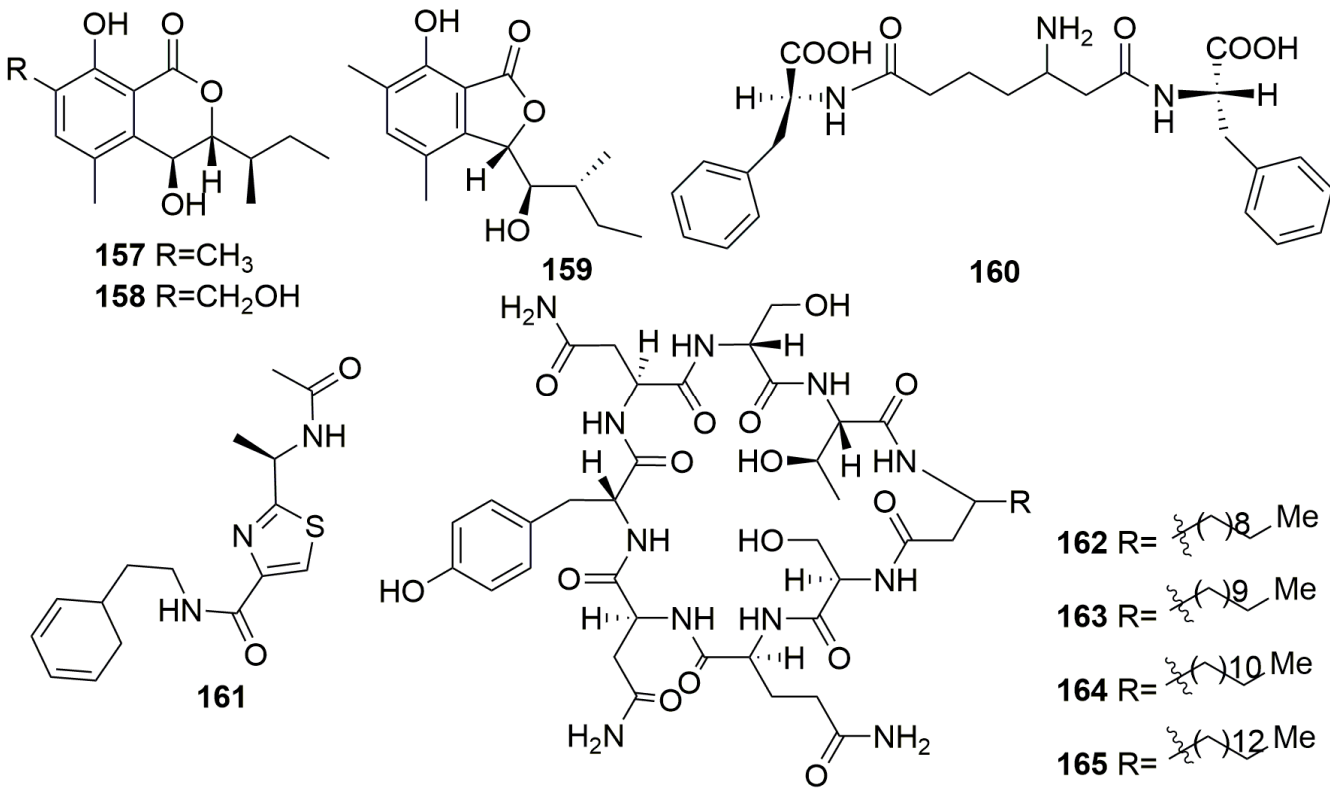

Figure 10. Chemical structures of compounds 157-165.

Family Dysideidae

A novel tripeptide containing a $\beta$-amino acid (160) (Figure 10) was metabolized by a bacterium Pseudomonas alteromonas from the marine sponge Dysidea fragilis (collected in the Black Sea, Bulgarian) [57]. A thiazole alkaloid, neobacillamide A (161) (Figure 10), was isolated from the bacterium Bacillus vallismortis C89 purified the South China Sea sponge Dysidea avara [58]. Four new cyclic lipopeptides based on the carbon nuclei cyclo-(AFA-Ser-Gln-Asn-Tyr-Asn-Ser-Thr), named cyclodysidins A-D (162-165) (Figure 10), were purified from the bacterium of Streptomyces strain RV15 associated with the sponge Dysidea tupha (collected from Rovinj, Croatia) [59].

Family Irciniidae

Cyclotetrapeptide (166) (Figure 11) was yielded in bacterium Pseudomonas sp. from the sponge Ircinia muscarum (collected in the gulf of Naples) [60]. Two first reported sorbicillin-derived alkaloids, sorbicillactones A-B (167-168), and one orbicillin derivative (169) as well as three novel sorbicillinol derivatives of mixed origin, sorbifuranones A-C (170-172) (Figure 11), were characterized from Penicillium chrysogenum associated with the Mediterranean sponge Ircinia fasciculata (Italy). Compound 167 exhibited a high anti-HIV activity in the concentration range from 0.3 to $3.0 \mu \mathrm{g} / \mathrm{mL}$, selective anti-leukemic activities, and furthermore, antiviral and neuroprotective properties [61,62]. Diketopiperazine alkaloid, an amauromine composed of two modified tryptophan units, which are cyclized forming a central diketopiperazine ring (173), a quinolinone derivitive, methyl-penicinoline (174), and one triterpene glycoside auxarthonoside (175) (Figure 11) were produced by the fungus Auxarthron reticulatum derived from the sponge Ircinia variabilis (the Island of Malta). Compound 173 dispalyed high affinity and selectivity for cannabinoid CB1 receptors [63,64]. The fungus Aspergillus tubingensis (strain OY907) isolated from the Mediterranean sponge Ircinia variabilis yielded a novel anhydride metabolite, tubingenoic anhydride A (176) (Figure 11) [65]. From the fungus Penicillium sp. (strain 101) derived from another Mediterranean sponge Ircinia oros (Turkey), a new fusarielin analogue (177) (Figure 11) was purified [66]. 


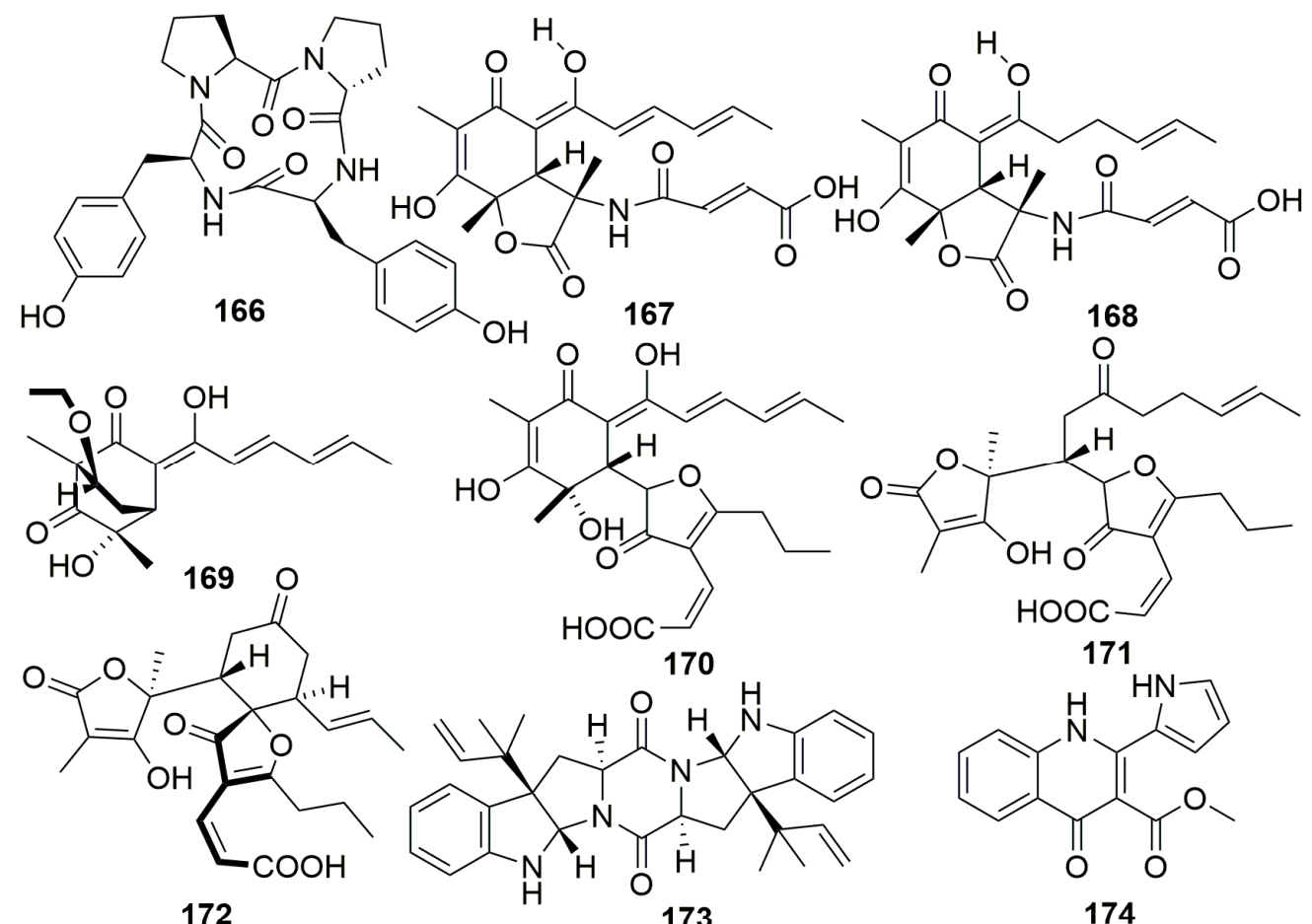

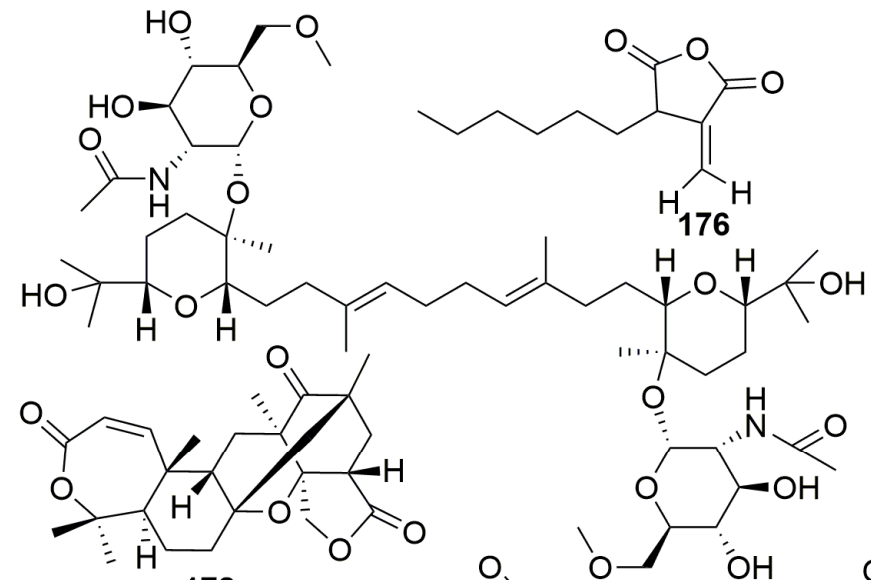<smiles>C/C=C(\C)[C@H]1[C@H](/C=C\C=C(/C)C(=O)O)[C@@H]2CC[C@@H](C)C[C@]2(C)C(=O)[C@]1(C)O</smiles>

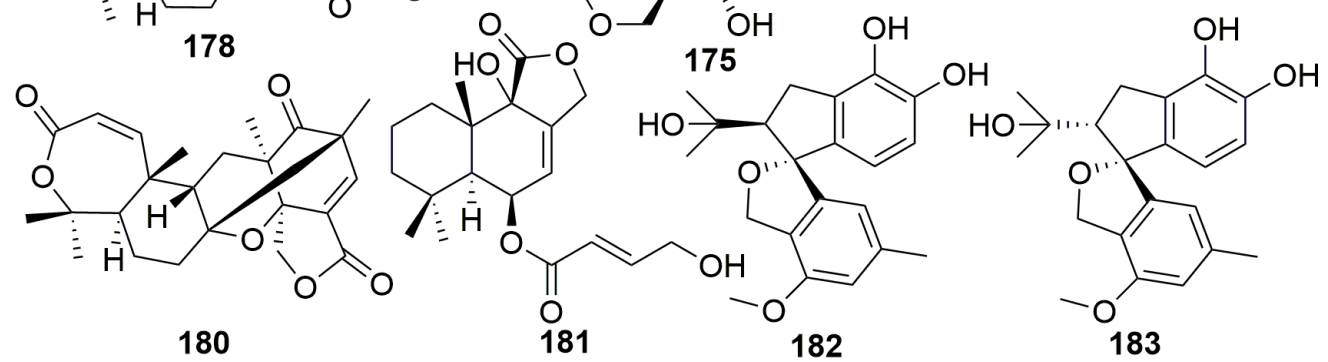

Figure 11. Chemical structures of compounds 166-183 produced by the fungus originated from the sponge Irciniidae.

The fungus Aspergillus insuetus (OY-207) originated from the Mediterranean sponge Psammocinia sp. (collected off-shore of Sdot-Yam, Israel), and it afforded three novel meroterpenoids insuetolides A-C (178-180) and one new drimane sesquiterpene (181) (Figure 11). Compound 178 exhibited antifungal activity toward Neurospora crassa [67]. Meroterpenoids spiroarthrinols A-B (182-183) (Figure 11) were found in fungus Arthrinium sp. associated with the marine sponge Sarcotragus muscarum (Turkey) [68]. 
Family Thorectidae

Six new polyketides, engyodontochone A-F (184-189) (Figure 12), were purified in fungus Engyodontium album strain LF069 originally separated from the sponge tissue of Cacospinga scalaris sampled at the Limski Fjord, Croatia. Compounds 186-189 represented the first example of a 23, a 28 seco-beticolin carbon skeleton, and compounds 184-185 exhibited inhibitory activity that was 10-fold stronger than chloramphenicol against methicillin-resistant Staphylococcus aureus [69]. The strain Pseudoalteromonas maricaloris KMM 636 ${ }^{\mathrm{T}}$ derived from the Australian sponge Fascaplysinopsis reticulata collected at the Great Barrier Reef was found to produce an inseparable mixture of two brominated yellow main pigments, bromoalterochromide A and $A^{\prime}$ (190) (Figure 12) in a ratio of 3:1. They showed cytotoxic effects on developing eggs of the sea urchin Strongylocentrotus intermedius (MIC, $40 \mu \mathrm{g} / \mathrm{mL}$ ) [70].

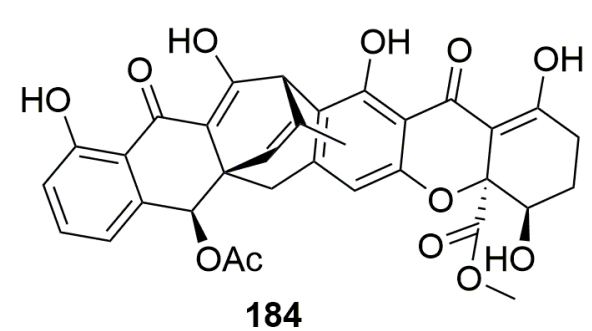

184<smiles>COC(=O)[C@@]1(C2CCC(=O)O2)CC(=O)c2c(cc3c(c2O)C2C=CC3C2C(O)=C2C(=O)c3c(O)cccc3C2OC(C)(C)C)O1</smiles>

186

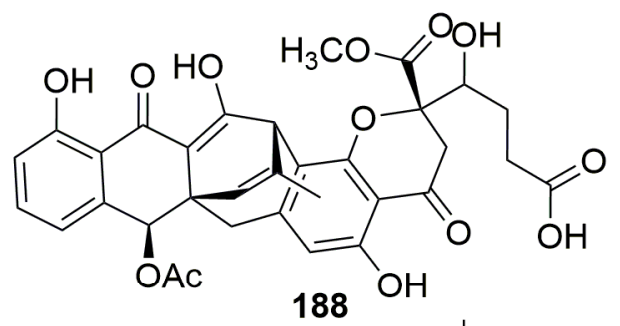<smiles>CC[C@H](C)[C@H](NC(=O)[C@H](CC(N)=O)NC(=O)[C@H](CC(N)=O)NC(=O)[C@H](NC(=O)C(C)C)C(C)C)C(=O)O</smiles>

$190 \mathrm{~A} ; \mathrm{A}^{\prime}$ is containing Leu instead of alle

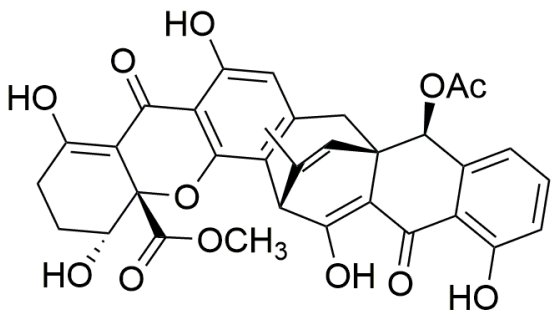

185

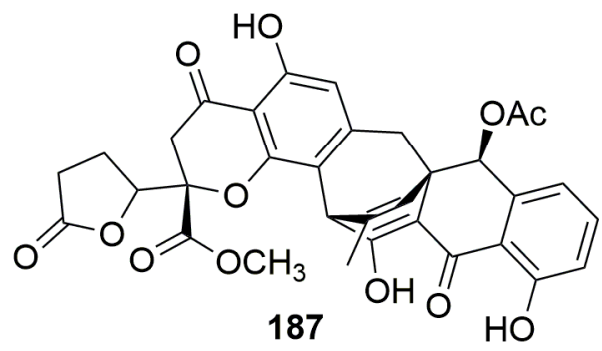

187

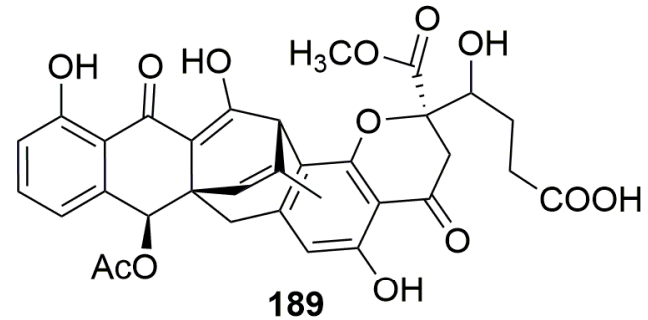

Figure 12. Structures of new marine natural products 184-190.

The cultures of Aspergillus niger separated from a Caribbean sponge, Hyrtios proteus, collected in the Dry Tortugas National Park, Florida, resulted in the isolation of a tetrahydrofuran-type derivative asperic acid (191) (Figure 13) [71]. The fungus Emericellopsis minima derived from the marine sponge Hyrtios erecta (Thailand) afforded a new bridged cyclic sesquiterpene (192) (Figure 13) [72]. A new 
alkaloid with an unprecedented carbon skeleton, penicillivinacine (193) (Figure 13), was produced by the fungus Penicillium vinaceum, which is associated with the marine sponge Hyrtios erectus (collected from Yanbu, Saudi Arabia). Compound 193 exhibited higher antimigratory activity than the positive control with an $\mathrm{IC}_{50}$ value of $18.4 \mu \mathrm{M}$ against the human breast cancer cell line MDA-MB-231 [73]. Examination of the fungus Trichoderma harzinum HMS-15-3 derived from the sponge Petrospongia nigra collected from South China Sea provided four pairs of new linear $\mathrm{C}_{13}$ lipid enantiomers with polyene and O-dinol structure, namely harzianumols A-H (194-201) (Figure 13). Their antihyperlipidemic effects in HepG2 cells were evaluated [74].

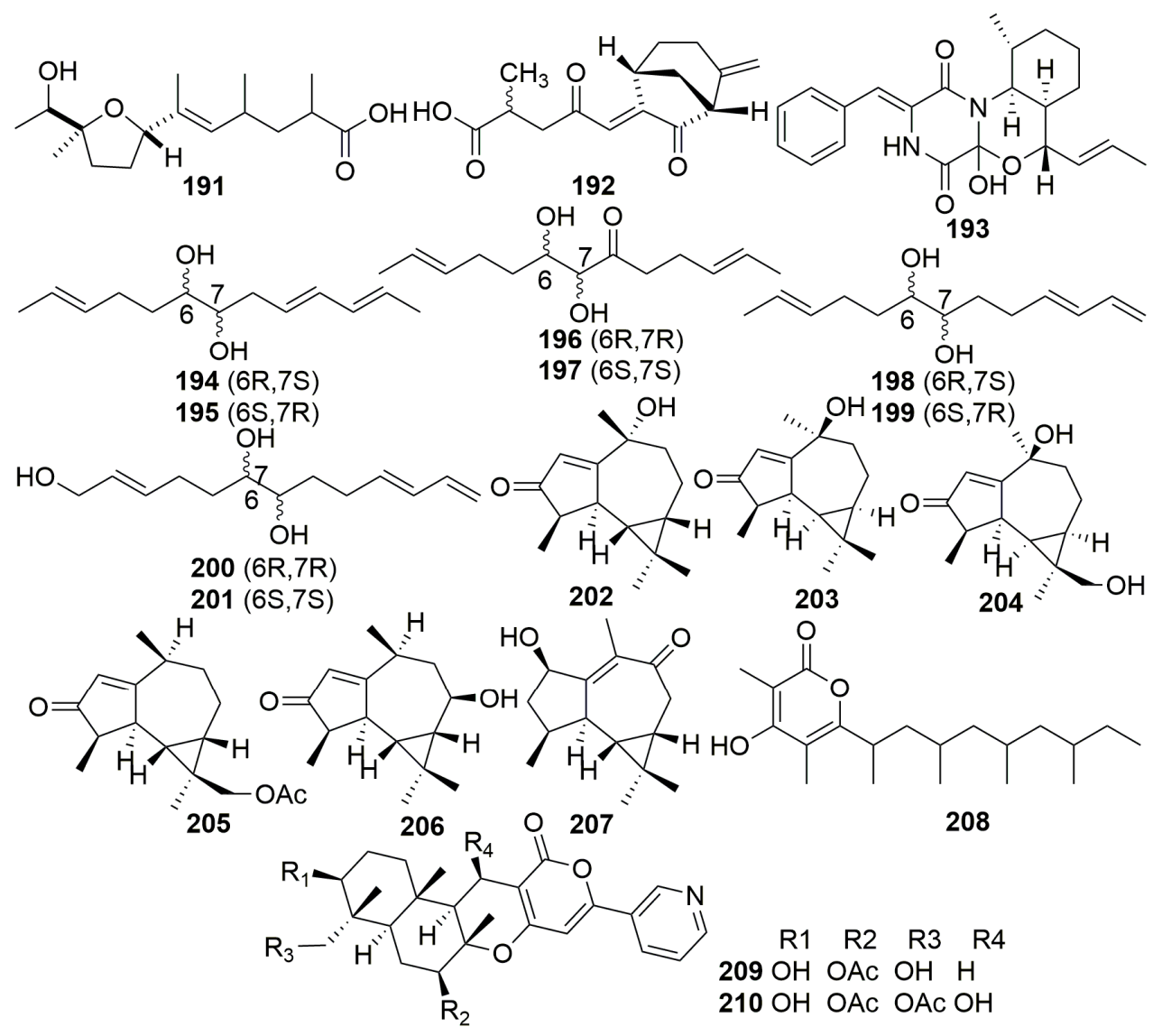

Figure 13. Structures of compounds 191-210 isolated from sponge-derived microorganisms.

Six new aromadendrane-type sesquiterpenoids, scedogiines A-F (202-207), and a new polyketide, scedogiine G (208) (Figure 13), were produced by the marine-derived fungus Scedosporium dehoogii F41-4, which is a symbiont on the sponge Phyllospongia foliascens collected from Hainan Sanya, China. Two new pyripyropenes (209-210) (Figure 13) were isolated from the other fungus Fusarium lateritium 2016F18-1, which is associated with the same sponge [75,76].

\subsubsection{Order Haplosclerida}

Family Callyspongiidae

Two novel spiciferone derivatives, spiciferol A (211) and a monocyclic butoxyl derivative (212) (Figure 14), were isolated from the fungus Drechslera hawaiiensis; it is associated with the marine sponge Callyspongia aerizusa, which is collected from the Mengangan Island, Indonesia [77]. Two new macrolide metabolites, pandangolide 3-4 (213-214), and the new phthalide herbaric acid (215) (Figure 14) were isolated from a fungal strain Cladosporium herbarum, which is associated with the marine sponge Callyspongia aerizusa (collected in Indonesia). However, their bioassays were disappointing [78,79]. Two 
new antibacterial phenazines (216-217) (Figure 14) were isolated from the bacteria Brevibacterium sp. KMD 003 associated with a marine purple vase sponge of the genus Callyspongia, which was collected in Korea. Compounds $\mathbf{2 1 6}$ and 217 showed antibacterial activities against Enterococcus hirae and Micrococcus luteus (MIC, $5 \mu \mathrm{M}$ ) [80]. The investigation of a fungus Stachylidium sp. from the sponge Callyspongia sp. cf. C. flammea (collected in Sydney, Australia) yielded three new phthalide derivatives, marilones A-C (218-220), four new, putatively tyrosine-derived and O-prenylated natural products, stachylines A-D (221-224), and four novel phthalimidine derivatives marilines: A1-A2 (225-226), B-C (227-228) (Figure 14). Compound 218 was found to have antiplasmodial activity against Plasmodium berghei liver stages with an $\mathrm{IC}_{50}$ of $12.1 \mu \mathrm{M}$. Compound 219 showed selective antagonistic activity toward the serotonin receptor $5-\mathrm{HT}_{2 \mathrm{~B}}$ with a $\mathrm{K}_{\mathrm{i}}$ value of $7.7 \mu \mathrm{M}$. Both compounds 225 and 226 inhibited human leukocyte elastase (HLE) with an $\mathrm{IC}_{50}$ value of $0.86 \mu \mathrm{M}$ [81-83].

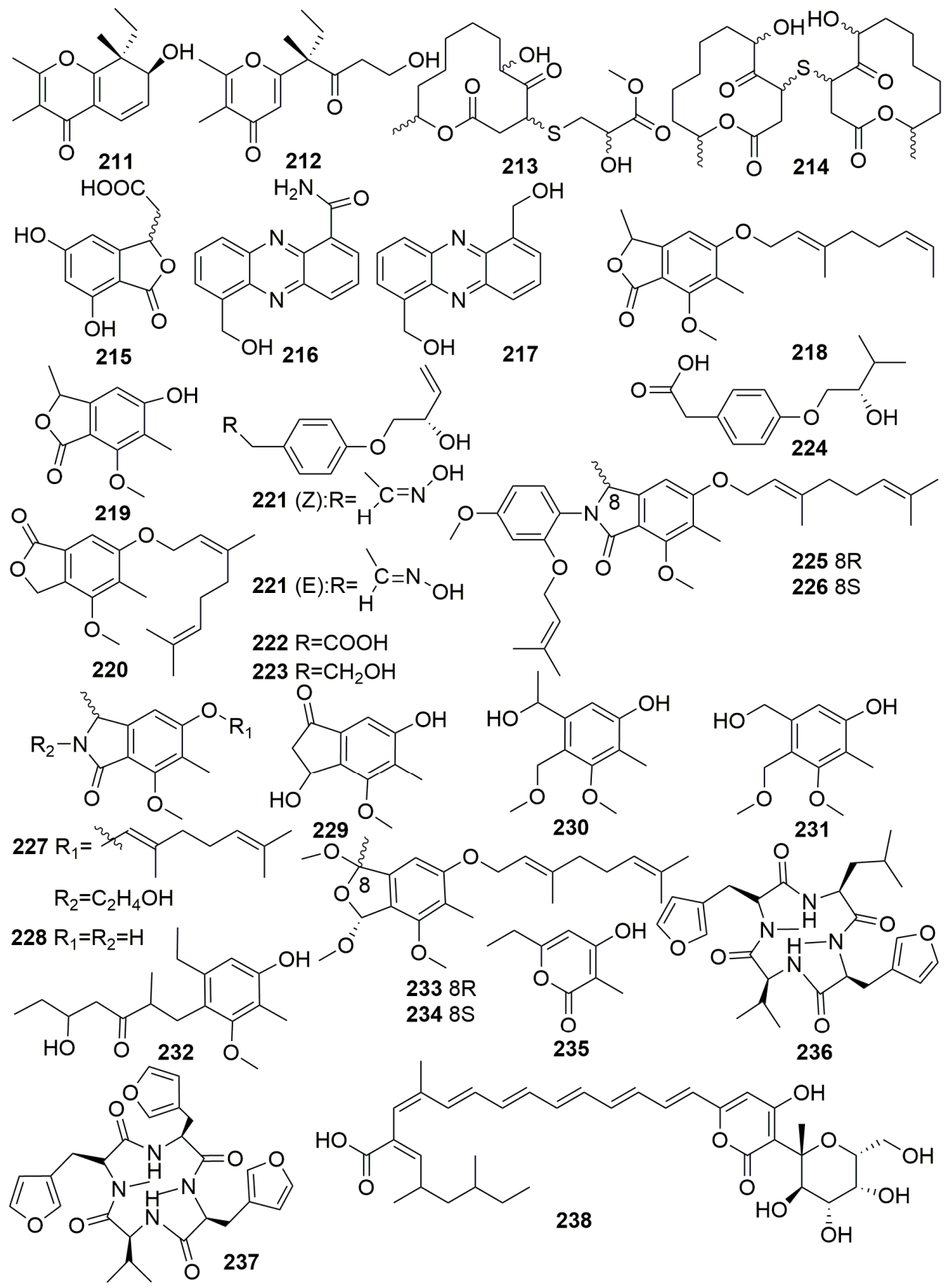

Figure 14. Chemical structures of compounds 211-238. 
Seven novel phthalide-related compounds, cyclomarinone (229), maristachones A-E (230-234), marilactone (235), and two new $N$-methylated tetrapeptides with amino acid 3-(3-furyl)-alanine, namely endolide A-B (236-237) (Figure 14), were isolated from the fungus Stachylidium sp., which was isolated from the sponge Callyspongia sp. cf. C. flammea (Australia). In their bioassays, compounds 229-235 showed no significant biological activities. Endolide A (236) showed affinity to the vasopressin receptor $1 \mathrm{~A}$ with a $\mathrm{K}_{\mathrm{i}}$ of $7.04 \mu \mathrm{M}$, and endolide B (237) was selective toward the serotonin receptor $5 \mathrm{HT}_{2 \mathrm{~b}} \mathrm{with}$ a $K_{i}$ of $0.77 \mu \mathrm{M}[84,85]$. A new pyronepolyene C-glucoside (238) was from fungus Epicoccum sp. JJY40, which was isolated from the sponge Callyspongia sp. collected in Hainan Province, China. Compound 238 (Figure 14) showed weak NF-kB (Proteins that can regulate gene expression) inhibitory ( IC $_{50}$ $40.0 \mu \mathrm{M})$ and significant inhibitory effects in the cytopathic effect (CPE) inhibition assay with $\mathrm{IC}_{50}$ value of $91.5 \mu \mathrm{M}$ (ribavirin as a positive control, $\mathrm{IC}_{50} 114.8 \mu \mathrm{M}$ ) [86].

Chemical examination of a marine fungus Alternaria sp. JJY-32, isolated from a sponge Callyspongia sp. (Hainan Island, China), yielded 13 meroterpenoids (239-251) (Figure 15). The NF- $\kappa$ B inhibitory activities of 239-251 were tested, and all of them, except 244 and $245\left(\mathrm{IC}_{50}>100 \mu \mathrm{M}\right)$, showed moderate to weak activities with $\mathrm{IC}_{50}$ values ranging from 39 to $85 \mu \mathrm{M}$ in RAW264.7 cells [87].

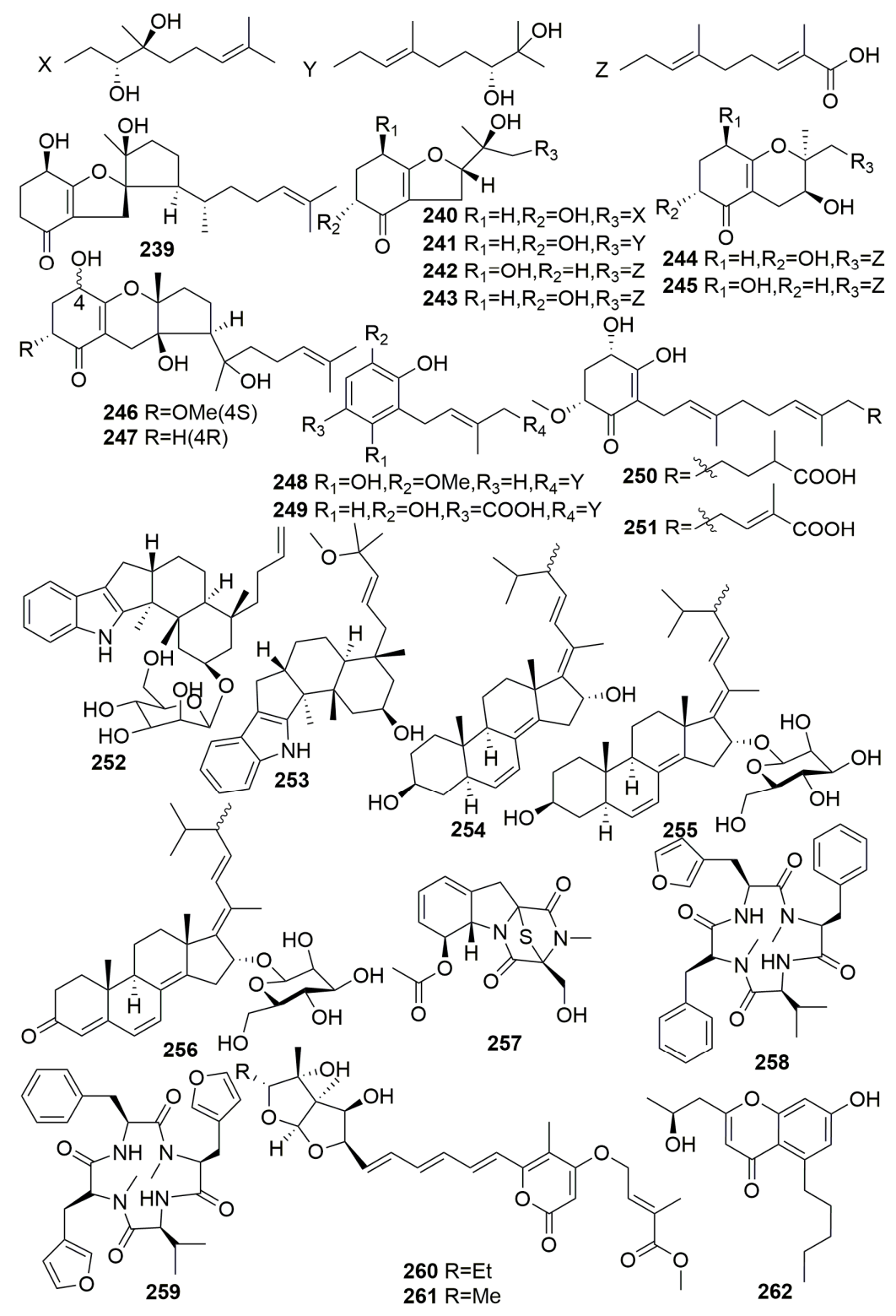

Figure 15. Structures of new marine natural products 239-262. 
The marine-derived fungus Dichotomomyces cejpii from the sponge Callyspongia sp. cf. C. flammea (Bear Island, Australia) afforded two new compounds, emindole SB betamannoside (252) and 27-O-methylasporyzin C (253), three new steroids (254-256), and a new gliotoxin derivative, 6-acetylmonodethiogliotoxin (257) (Figure 15). Compounds 252 and 253 may serve as lead structures for the development of GPR18- and CB receptor-blocking drugs. Compound 255 was found to be capable of preventing the enhanced production of amyloid $\beta-42$ in Aftin-5 treated cells in an Alzheimer's disease cellular assay. Compound 257 dose-dependently down-regulated TNF $\alpha$ (Tumor Necrosis Factor) -induced NF-kB (Proteins that can regulate gene expression) activity in human chronic myeloid leukemia cells with an $\mathrm{IC}_{50}$ of $38.5 \pm 1.2 \mu \mathrm{M}$ [88-90]. The chemical study of a marine-derived fungus Stachylidium sp. 293 K04 from the sponge Callyspongia sp. cf. C. flammea (Bare Island, Australia) afforded two new tetrapeptide analogues, endolides C-D (258-259) (Figure 15) [91]. The marine sponge-derived fungus, Aspergillus sp. SCSIO XWS02F40, derived from a sponge Callyspongia sp. (Guangdong Province, China), afforded two new asteltoxins named asteltoxin E-F (260-261) and a new chromone (262) (Figure 15). Compound 260 showed significant activity against H3N2 and exhibited inhibitory activity against $\mathrm{H} 1 \mathrm{~N} 1$ with the prominent $\mathrm{IC}_{50}$ values of $6.2 \pm 0.08$ and $3.5 \pm 1.3 \mu \mathrm{M}$, respectively. Compound 261 showed significant activity against $\mathrm{H} 3 \mathrm{~N} 2$ with an $\mathrm{IC}_{50}$ value of $8.9 \pm 0.3 \mu \mathrm{M}$ [92].

\section{Family Chalinidae}

One new vertinoid polyketide (263) (Figure 16) was characterized from a marine-derived fungus Trichoderma longibrachiatum associated with a sponge Haliclona sp. collected from Sulawesi, Indonesia [93]. Three new cyclic sesquiterpenes, hirsutanols A-C (264-265) and ent-gloeosteretriol (266) (Figure 16), were metabolized by an unidentified fungus separated from an Indo-Pacific sponge Haliclona sp. Compounds 264 and 266 were antimicrobial toward Bacillus subtilis [94]. Chemical investigation of the marine-derived fungus Emericella variecolor isolated from the marine sponge Haliclona valliculata (Elba/Italy) led to the isolation of two new natural products, evariquinone and isoemericellin (267-268) (Figure 16). Compound 267 showed antiproliferative activity toward KB and NCI-H460 cells at a concentration of $3.16 \mu \mathrm{g} / \mathrm{mL}$ [95]. Two new macrolactams, cebulactams A1-A2 (269-270) (Figure 16), were metabolized by the genus Saccharopolyspora cebuensis-type strain SPE 10-1 associated with the sponge Haliclona sp. collected offshore Cebu, Philippines [96].

From a strain of Streptomyces sp. NBRC 105896 derived from a marine sponge Haliclona sp. (collected from Chiba Prefecture, Japan), JBIR-31, a new teleocidin analog (271) (Figure 16), was isolated. Compound 271 showed weak cytotoxic effects against HeLa with $\mathrm{IC}_{50}$ value of $49 \mu \mathrm{M}$ [97]. Two new modified indole-containing peptides, JBIR 34-35 (272-273) (Figure 16), were produced by a marine-derived actinomycete Streptomyces sp. (strain Sp080513GE-23) originally derived from a marine sponge, Haliclona sp. (collected from Chiba Prefecture, Japan). Both compounds exhibited weak DPPH radical scavenging activity [98]. Two new anthracyclines, tetracenoquinocin (274) and 5-iminoaranciamycin (275) (Figure 16), were isolated from the culture broth of Streptomyces sp. Sp080513GE-26 collected from a marine sponge, Haliclona sp. (collected from Chiba Prefecture, Japan). Only compound 274 exhibited weak cytotoxicities with $\mathrm{IC}_{50}$ values of 120 and $210 \mu \mathrm{M}$ against HeLa and HL-60 cells, respectively [99]. A new compound JBIR-107 (276) (Figure 16) was isolated from the culture of Streptomyces tateyamensis NBRC105047 isolated from the marine sponge, Haliclona sp. [100]. 


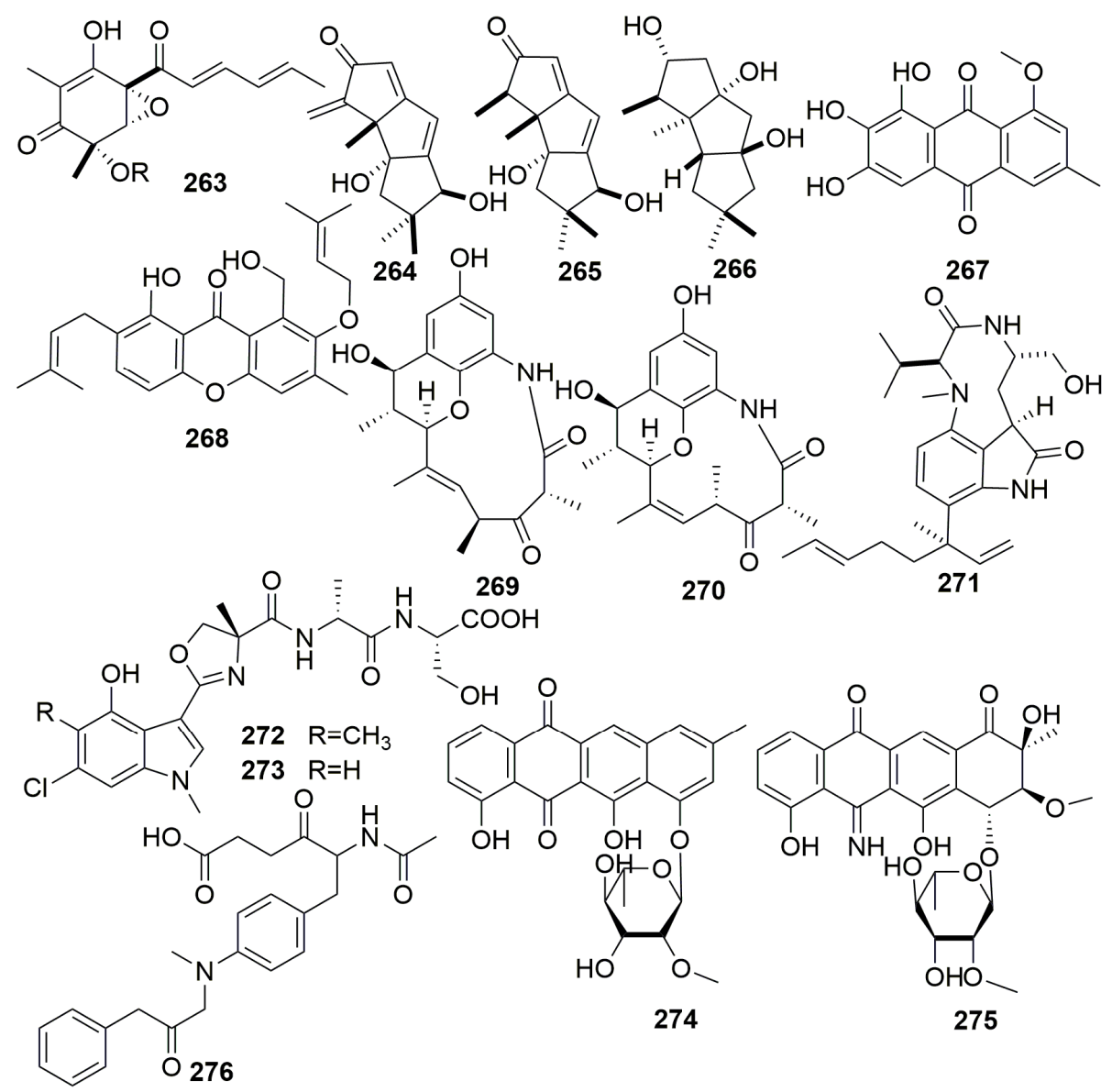

Figure 16. Chemical structures of compounds 263-276.

Family Niphatidae

Chemical examination of a marine fungus, Truncatella angustata XSB-01-43, isolated from a finger sponge Amphimedon sp. (collected in Yongxin Island, China), yielded 14 new isoprenylated cyclohexanols, namely truncateols A-N (277-290), and five new a-pyrone-based analogues, namely angupyrones A-E (291-295) (Figure 17). Compounds 279, 281, and 289 exerted significant inhibitory effects with $\mathrm{IC}_{50}$ values of $8.8-63 \mu \mathrm{M}$ against $\mathrm{H} 1 \mathrm{~N} 1$ virus (oseltamivir as a positive control, $\mathrm{IC}_{50}$ $46.5 \mu \mathrm{M}$ ). Compounds 291-295 exhibited moderate antioxidant response element activation in HepG2C8 cells [101,102].

Five new isocoumarins, namely peyroisocoumarins A-D (296-299) and isocitreoisocoumarinol (300) (Figure 17) were produced by the sponge-associated fungus Peyronellaea glomerate, which was derived from a finger sponge Amphimedon sp. (Yongxin Island, China). Compounds 296, 297, and 299 exerted potent antioxidant response element activation in HepG2C8 cells [103]. Two new cadinane-type sesquiterpenes, hypocreaterpenes A-B (301-302) (Figure 17) were isolated from the fungal strain Hypocreales sp. strain HLS-104, which was isolated from a sponge Gelliodes carnosa; however, their bioassays were disappointing [104]. Two new monoterpenoid a-pyrones, named nectriapyrones C-D (303-304) (Figure 17), were isolated from the fungal strain Nectria sp. HLS206, which was isolated from the marine sponge Gelliodes carnosa collected from the South China Sea. None of them exhibited antibacterial activity nor cytotoxic activity [105]. Chemical study of the marine-derived Streptomyces sp. LS298 from the marine sponge Gelliodes carnosa (collected from Hainan Province, China) afforded a new analogue of echinomycin quinomycin $G$ (305), together with a new cyclic dipeptide, cyclo-(L-Pro-4-OH-L-Leu) (306) (Figure 17). Compound 305 exhibited moderate antibacterial activities against Staphylococcuse pidermidis, S. aureus, Enterococcus faecium, and E. faecalis with MIC values ranging 
from 16 to $64 \mu \mathrm{g} / \mathrm{mL}$ and displayed remarkable anti-tumor activities against the tested cell lines ACHN, 786-O, and U87 MG [106].

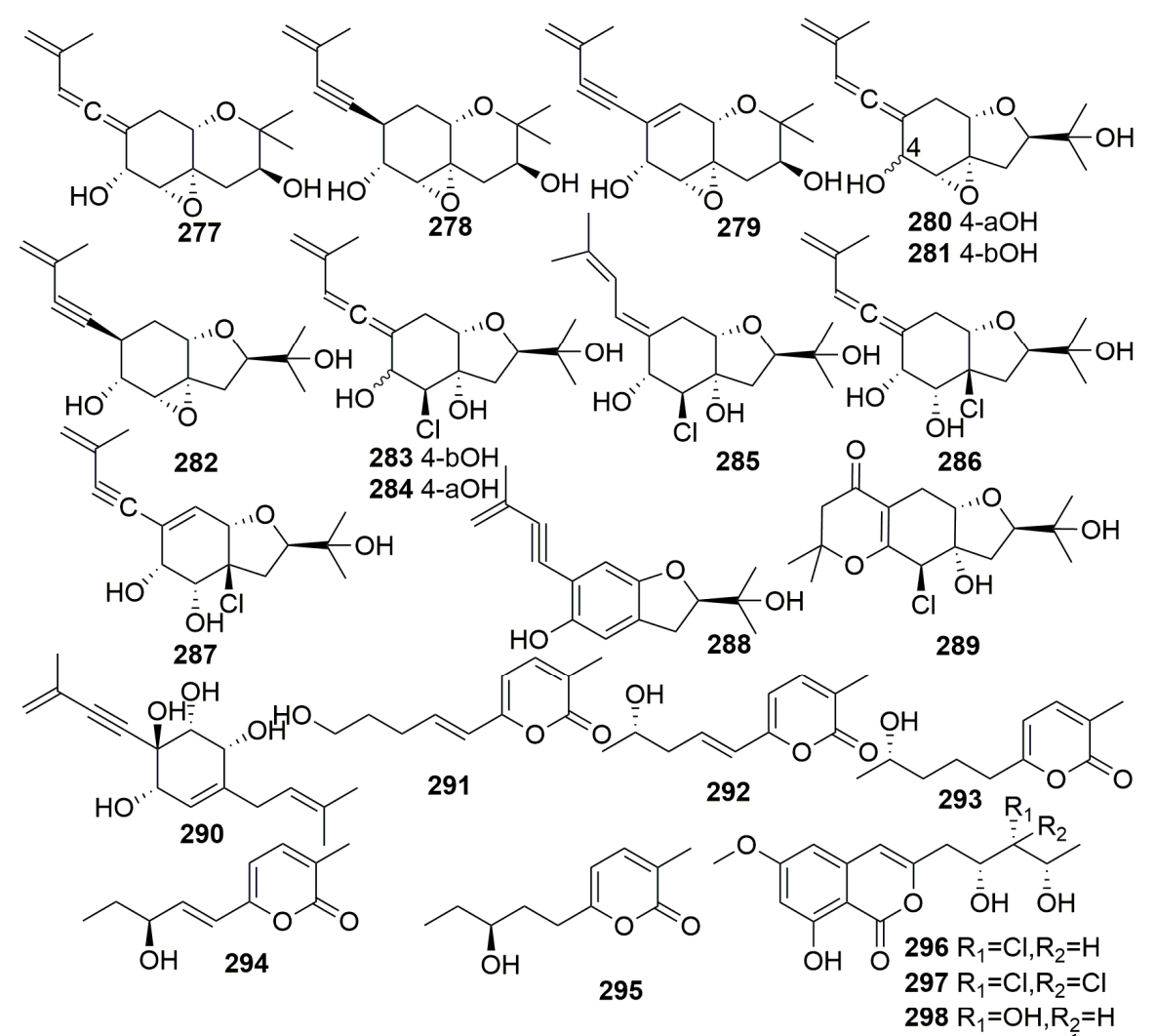

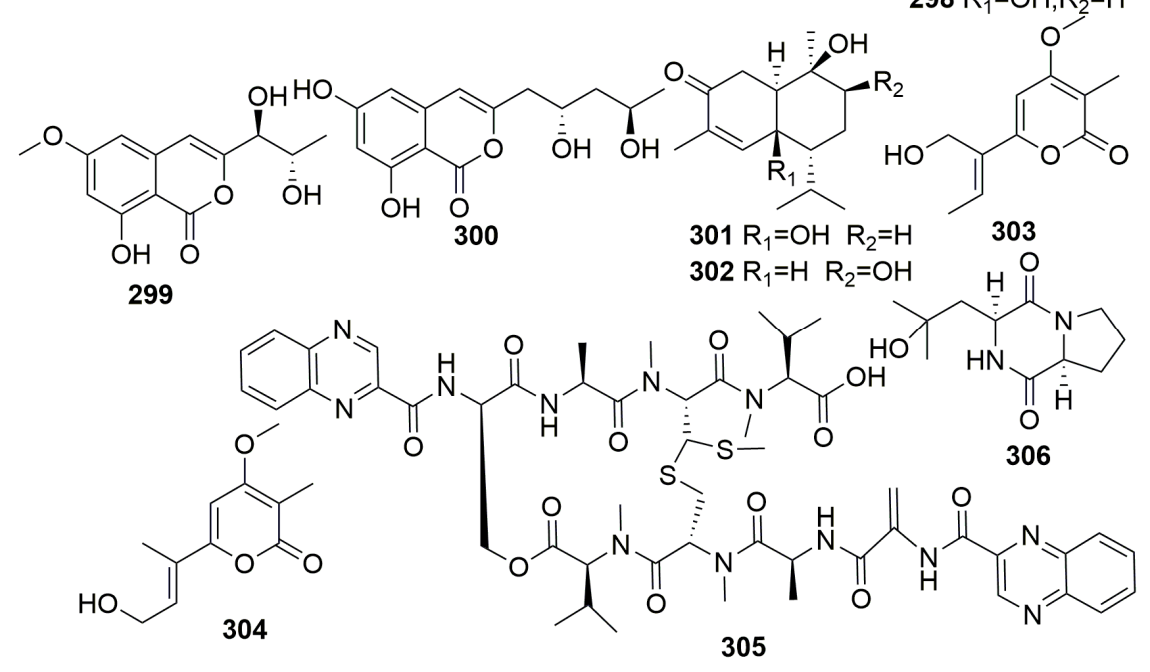

Figure 17. Chemical structures of new molecules 277-306.

The fungus Curvularia lunata was isolated from the marine sponge Niphates olemda (collected in Indonesia), and it yielded the new 1,3,8-trihydroxy-6-methoxyanthraquinone, which we named lunatin (307) (Figure 18). Compound 307 exhibited antibacterial activities against Bacillus subtilis, Staphylococcus aureus, and Escherichia coli [79]. A new hexaketide, pandangolide 1a (308) (Figure 18), was detected in the fungal strain Cladosporium sp., which was originally separated from the Red Sea sponge Niphates rowi [107]. The examination of the sponge-associated fungus Stachybotrys chartarum was isolated from the sponge Niphates sp. (GuangXi Province, China), and it led to the isolation of eight new isoindolinone-type alkaloids named chartarutines A-H (309-316) (Figure 18). Chartarutines 310, 315, and 316 exhibited significant inhibitory effects against HIV-1 virus [108]. 


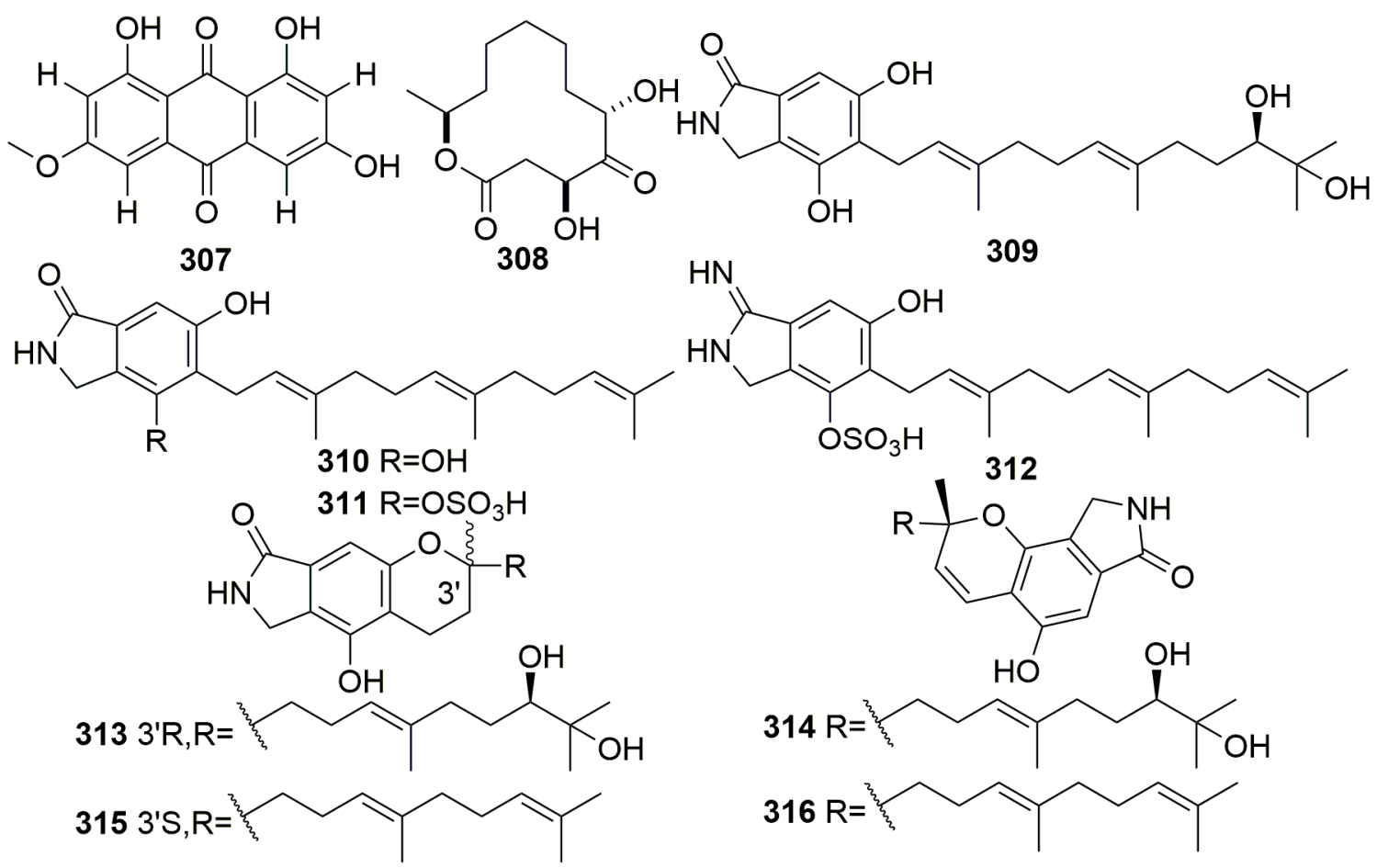

Figure 18. Chemical structures of compounds 307-316.

Chemical analysis of a fungus Stachybotrys chartarum isolated from the sponge Niphates recondite WGC-25C-6 (Guangxi Province, China) afforded 16 new phenylspirodrimanes, named chartarlactams A-P (317-332), four new compounds, namely chartarenes A-D (333-336), and three phenylspirodrimane-based meroterpenoids with novel scaffolds, namely chartarolides A-C (337-339) (Figure 19). Compounds 320-322, 327, and 330-331 exhibited moderate antihyperlipidemic activities in HepG2 cells. Compounds 333-339 exerted potent or selective inhibition against a panel of tumor cell lines (including HCT-116, HepG2, BGC-823, NCIH1650, and A2780) and showed strong inhibitory activities against the human tumor-related protein kinases of FGFR3, IGF1R, PDGFRb, and TrKB [109-111].

Six new caryophyllene-based sesquiterpenoids named punctaporonins $\mathrm{H}-\mathrm{M}$ (340-345), 10 new resorcinol derivatives named hansfordiols A-J (346-355), and three new salicylic acid derivatives (356-358) (Figure 20) were isolated from the marine fungus Hansfordia sinuosae, which was previously isolated from the sponge of Niphates sp. collected from Southern China Sea. Punctaporonin K (343) exhibited potent effects to reduce the triglycerides and total cholesterol in the intracellular levels. Compounds 340-345 showed weak cytotoxic activity against a panel of tumor cell lines with $\mathrm{IC}_{50}$ values more than $10 \mu \mathrm{M}$ and showed weak inhibitory effects against the bacterial strains with the MIC values more than $125 \mu \mathrm{M}$. Compounds 346-358 did not do well in their bioassays [112-114]. 


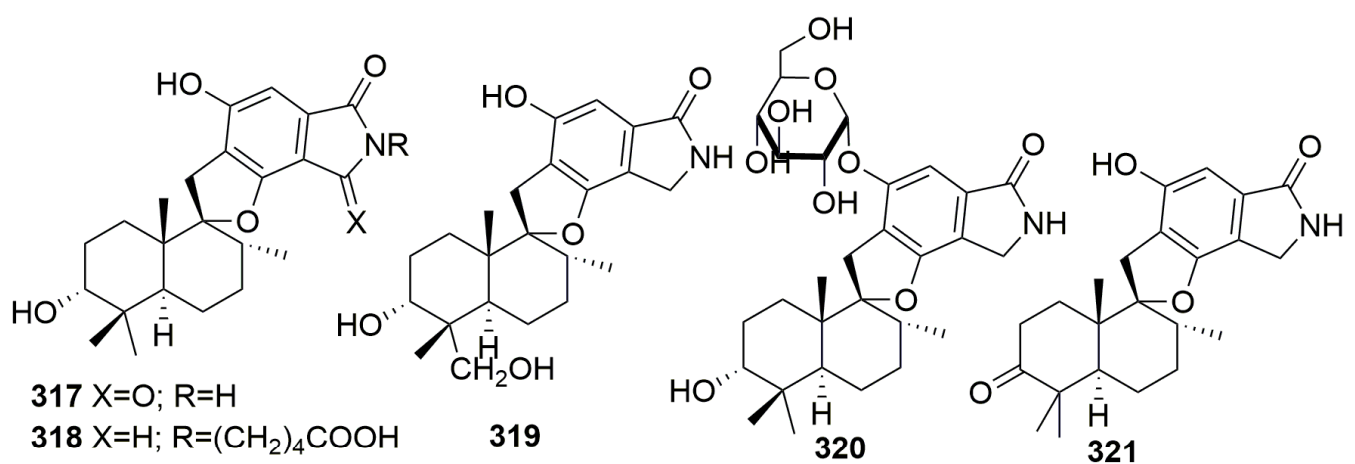

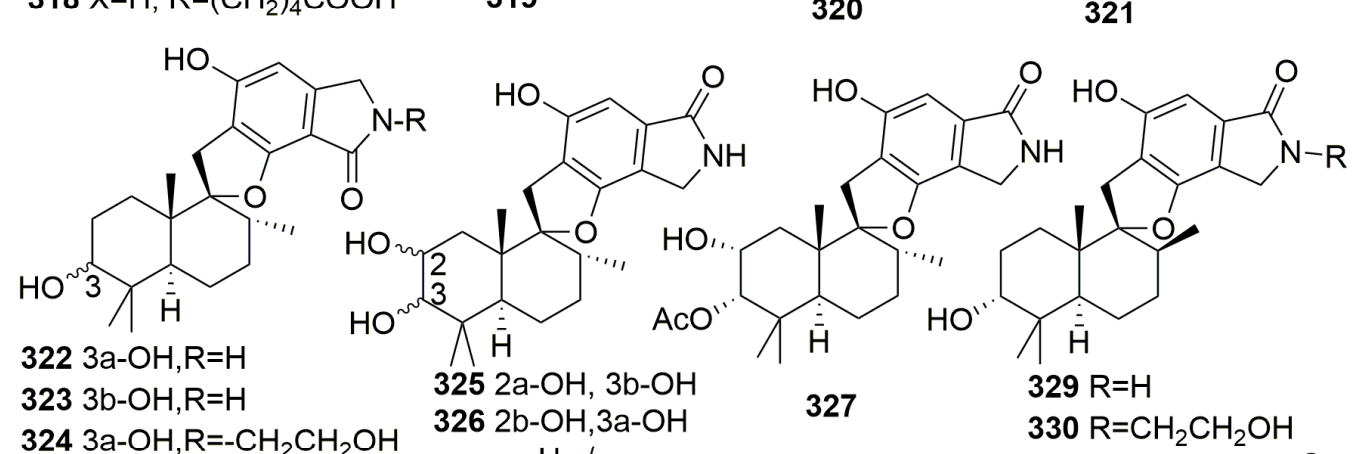

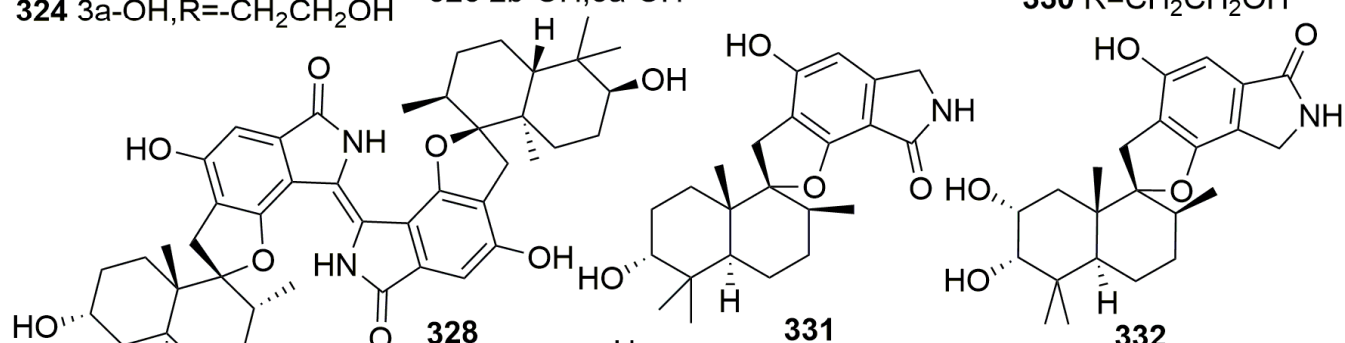

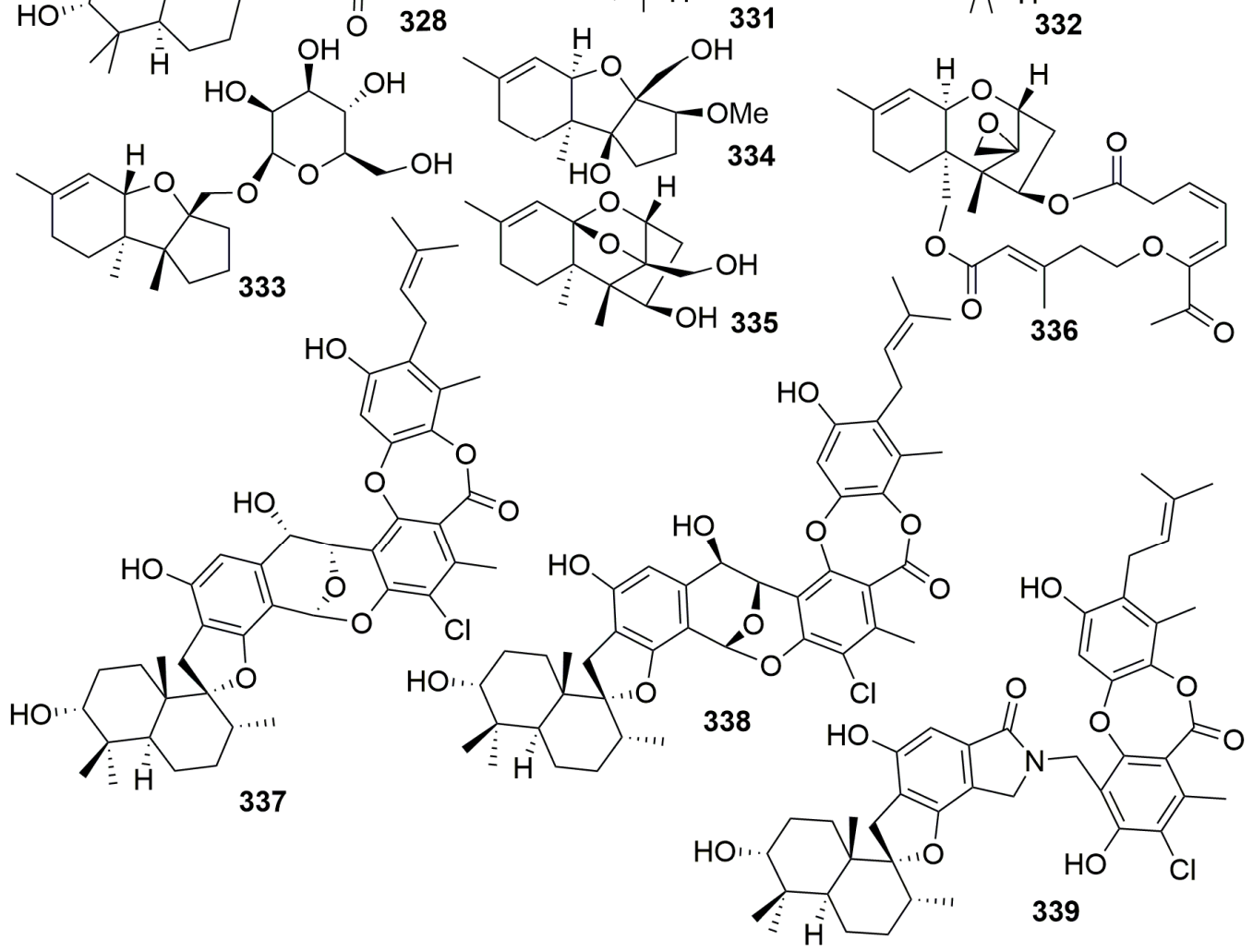

Figure 19. Chemical structures of molecules 317-339 isolated from the above fungus Stachybotrys chartarum. 


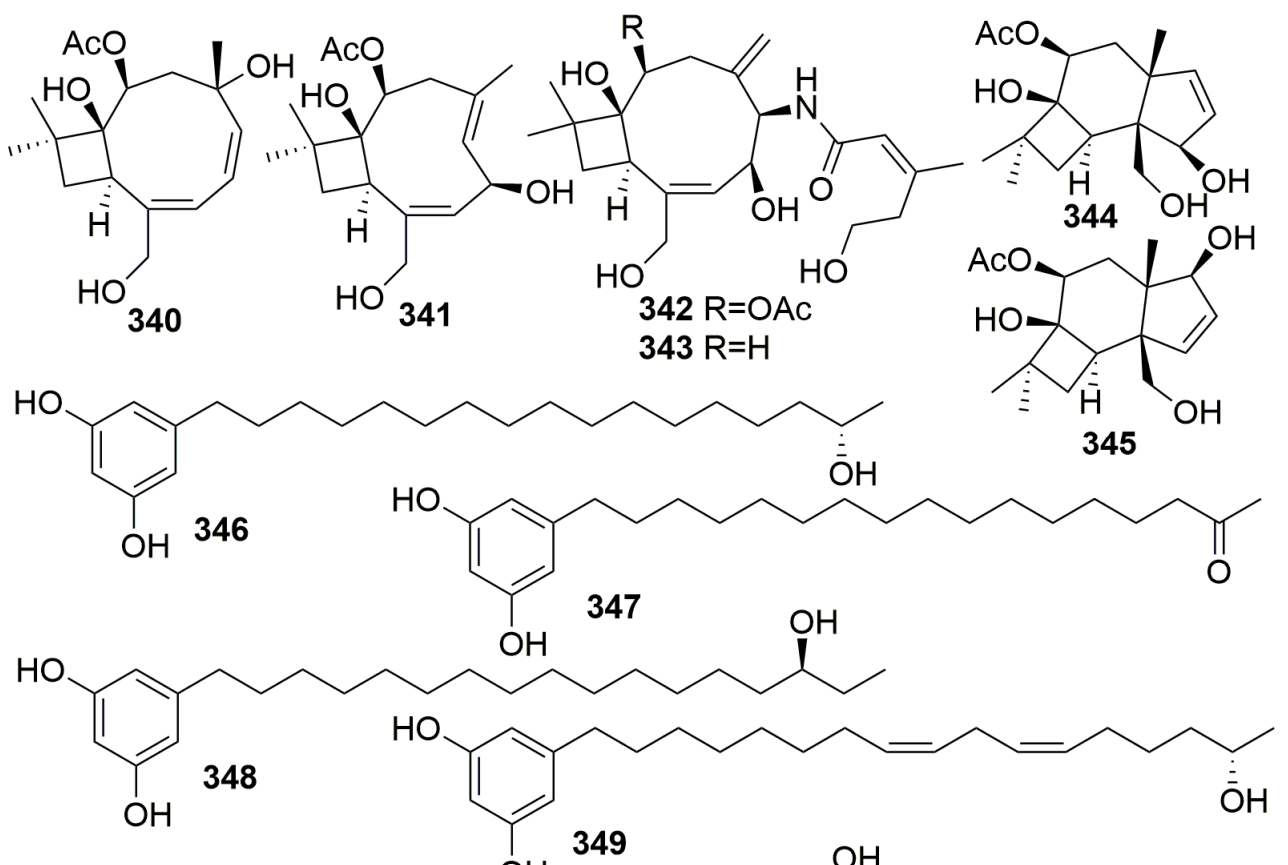<smiles>CC[C@H](O)CCCCCC/C=C\CCCCCCCc1cc(O)cc(O)c1</smiles>

Figure 20. Chemical structures of diverse new molecules 340-358 isolated from microorganisms.

Family Petrosiidae

The investigation of the Mediterranean sponge Petrosia ficiformis-derived fungus, Penicillium brevicompactum, yielded two previously unknown cyclodepsipeptides, petrosifungins A-B (359-360) (Figure 21) [115]. Five new compounds, pichiafurans A-C (361-363) and pichiacins A-B (364-365) (Figure 21), were isolated from the yeast Pichia membranifaciens derived from a marine sponge Petrosia sp. collected from South Korea [116]. New $\alpha$-pyrones (366-367) and cyclohexenones (368-369) (Figure 21) were isolated from the fungus Paecilomyces lilacinus, which is a strain derived from a marine sponge Petrosia sp. (collected from Jeju Island) [117]. Two new meroterpenoids, terretonins E-F (370-371) (Figure 21), were detected in the marine-derived fungus Aspergillus insuetus associated with the sponge Petrosia ficiformis collected in the Mediterranean Sea. Compounds 370-371 showed activity as inhibitors of the mammalian mitochondrial respiratory chain with $\mathrm{IC}_{50}$ values of $3.90 \pm 0.4$ 
and $2.97 \pm 1.2 \mu \mathrm{M}$, respectively [118]. A study on the sponge-derived fungus Aspergillus versicolor derived from the sponge Petrosia sp. (collected in Jeju Island, Korea) afforded a new peptide (372) and a new lipopeptide named fellutamide F (373) (Figure 21). Both compounds showed moderate cytotoxiciy against a panel of tumor cell lines (such as the skin cancer and colon cancer cells) with $\mathrm{IC}_{50}$ values ranging from 0.13 to $33.1 \mu \mathrm{M}[119,120]$. Two naturally rare dimeric indole derivatives (374-375) (Figure 21) were isolated from the marine actinomycete Rubrobacter radiotolerans cultured from a marine sponge Petrosia sp. (collected in Xisha Islands, China) and showed moderate acetylcholinesterase (AchE) inhibitory activity with $\mathrm{IC}_{50}$ values of 11.8 and $13.5 \mu \mathrm{M}$, respectively [121]. Futher examination of the sponge-derived actinomycete Rubrobacter radiotolerans produced one new dimeric indole derivative (376) (Figure 21), which exhibited the most effective antichlamydial activity with $\mathrm{IC}_{50}$ values of 46.6-96.4 $\mu \mathrm{M}$ [122]. A new diphenyl ether derivative, circinophoric acid (377) (Figure 21), was purified from the fungus strain of Sporidesmium circinophorum KUFA 0043 associated with the marine sponge Petrosia sp., which was collected from the Gulf of Thailand. The compound was disappointing in its bioassays [123].
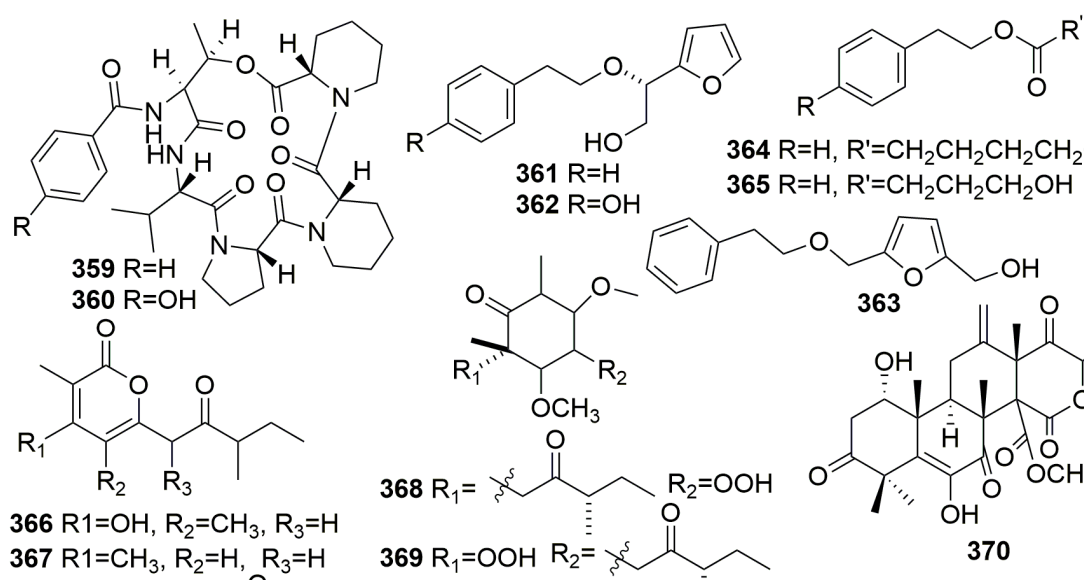

$364 \mathrm{R}=\mathrm{H}, \mathrm{R}^{\prime}=\mathrm{CH}_{2} \mathrm{CH}_{2} \mathrm{CH}_{2} \mathrm{CH}_{2} \mathrm{OH}$ $362 \mathrm{R}=\mathrm{OH} \quad 365 \mathrm{R}=\mathrm{H}, \mathrm{R}^{\prime}=\mathrm{CH}_{2} \mathrm{CH}_{2} \mathrm{CH}_{2} \mathrm{OH}$

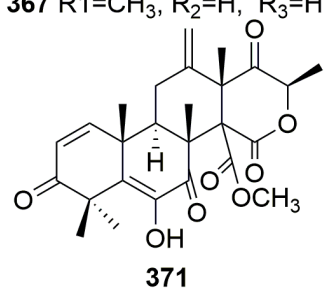<smiles>[R2]O[C@H]1C([R2])[C@H](OC)[C@@H](C)C(=O)[C@]1([R1])C</smiles><smiles></smiles><smiles>CCCCCCCCCC(O)CC</smiles>

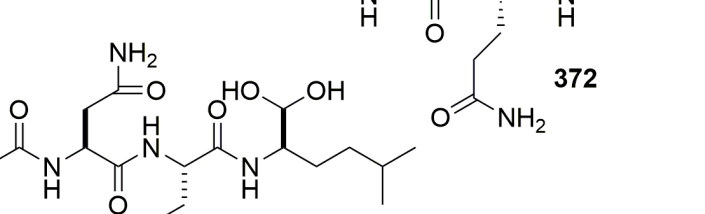
373<smiles>COC(=O)c1cc(O)cc(OC)c1Oc1cc(C)cc(OC)c1C(=O)O</smiles>

Figure 21. Chemical structures of diverse new molecules 359-377 isolated from sponge-derived microorganisms.

Four novel secondary metabolites, namely aspergillone 1-3 (378-380) and 12-acetyl-aspergillol 4 (381) (Figure 22), were metabolized by fungus Aspergillus versicolor isolated from the marine sponge Xestospongia exigua (Indonesia) [124]. A marine strain of Penicillium cf. montanense derived from the marine sponge Xestospongia exigua (collected from the Bali Sea, Indonesia) was found to metabolize three novel decalactone metabolites, xestodecalactones A-C (382-384) (Figure 22). 
Compound 383 exhibited antifungal activity against the yeast Candida albicans [125]. Seven new angular tricyclic chromone derivatives (385-391) (Figure 22) were isolated from a fungus Aspergillus versicolor colonized in the marine sponge Xestospongia exigua (Indonesia). In the selected bioassay systems, only aspergillitine (385) displayed moderate antibacterial activity against Bacillus subtilis [126]. A new tyrosine-derived metabolite, aspergillusol A (392), and a novel sesquiterpenoid, asperaculin A (393) (Figure 22), were metabolized by the fungal strain Aspergillus aculeatus CRI323-04 associated with the marine sponge Xestospongia testudinaria (specimen no. CRI323) (Krabi Province). Compound 392 selectively inhibited $\alpha$-glucosidase from the yeast Saccharomyces cerevisiae $[127,128]$. Four new bisabolane-type sesquiterpenoids, aspergiterpenoid A (394), (-)-sydonol (395), (-)-sydonic acid (396), (-)-5-(hydroxymethyl)-2-(2',6',6'-trimethyltetrahydro-2H-pyran-2-yl) phenol (397), and three new phenolic bisabolane sesquiterpenoid dimers, disydonols A-C (398-400) (Figure 22), were detected in the cultures of the marine-derived fungal strain Aspergillus sp., which was isolated from the sponge Xestospongia testudinaria (South China Sea). Compounds 394-397 showed selective antibacterial activity against eight bacterial strains (MIC values, 1.25-20.0 $\mu \mathrm{M}$ ). Compounds 398 and 400 exhibited cytotoxicity against HepG-2 and Caski human tumor cell lines [129,130].

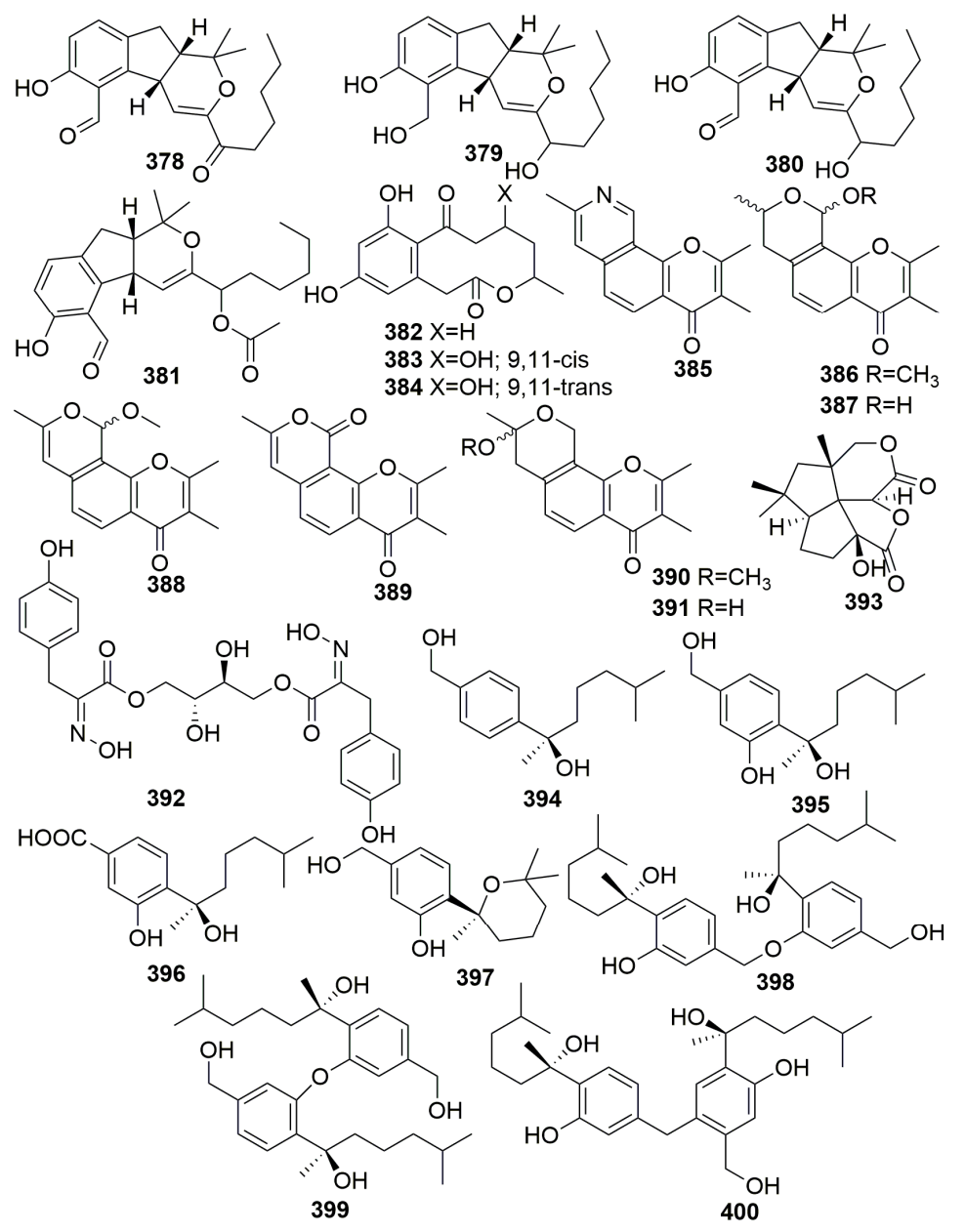

Figure 22. Chemical structures of new marine natural products 378-400 isolated from microorganisms.

Three naturally new C-glycosylated benz[a]anthraquinone derivatives-urdamycinone E (401), urdamycinone G (402), and dehydroxyaquayamycin (403) (Figure 23)-were from the marine Streptomycetes sp. BCC45596, which was isolated from a marine sponge, Xestospongia sp. (Thailand). Compounds 401-403 exhibited potent antiplasmodial activity toward the Plasmodium falciparum $\mathrm{K} 1$ strain with $\mathrm{IC}_{50}$ values in a range of $0.0534-2.93 \mu \mathrm{g} / \mathrm{mL}$, anti-Mycobacterium tuberculosis with 
MICs in a range of 3.13-12.50 $\mu \mathrm{g} / \mathrm{mL}$ and cytotoxicity against cancerous (KB, MCF-7, NCI-H187) and non-cancerous (Vero) cells with $\mathrm{IC}_{50}$ values in a range of $0.092-10.07 \mu \mathrm{g} / \mathrm{mL}$ [131]. The chemical examination of a marine-derived fungus Stachybotrys chartarum MXH-X73 from the sponge Xestospongia testudinaris (Xisha Island, China) afforded seven new phenylspirodrimanes, named stachybotrins D-F (404-406), stachybocins E-F (407-408), stachybosides A-B (409-410), and a new sulfate meroterpenoid, stachybotrin G (411) (Figure 23). Only compound 404 exhibited anti-HIV activity by targeting reverse transcriptase $[132,133]$. Chemical examination of a Streptomyces species (S.4), isolated from the sponge Xestospongia muta collected from the Florida Keys, yielded a new dipeptide named xestostreptin (412) (Figure 23). Compound 412 exhibited weak antiplasmodial activity against the Dd2 strain of Plasmodium falciparum, with $\mathrm{IC}_{50}$ values of $50 \mu \mathrm{M}$ [134].

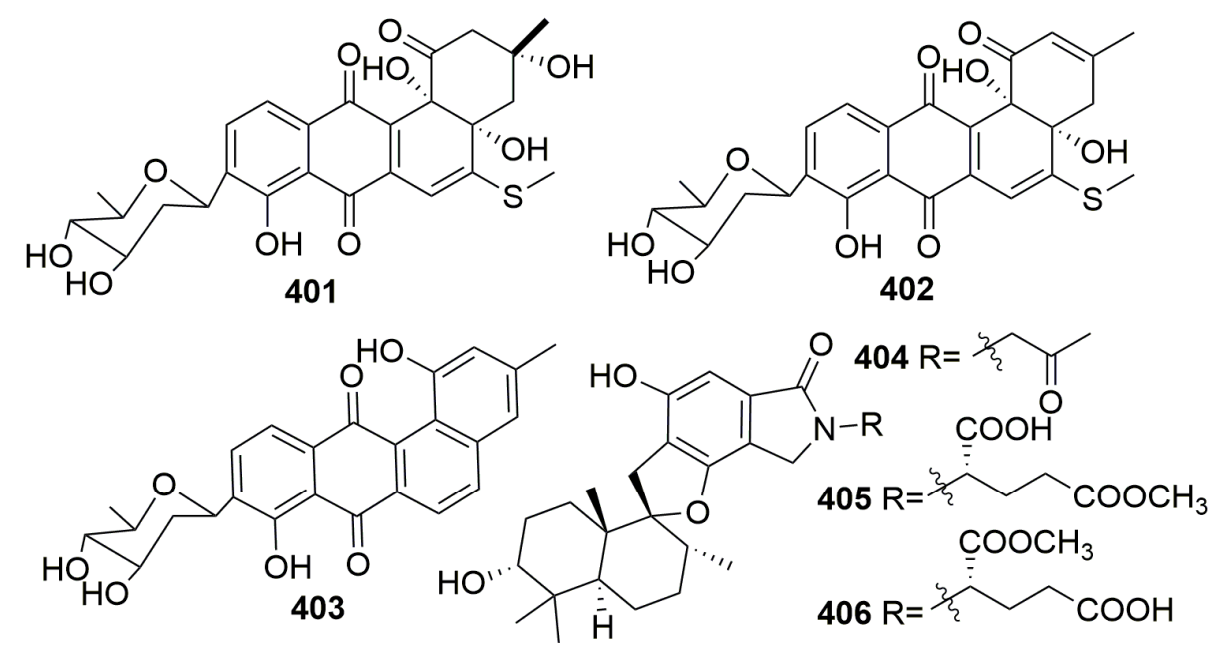

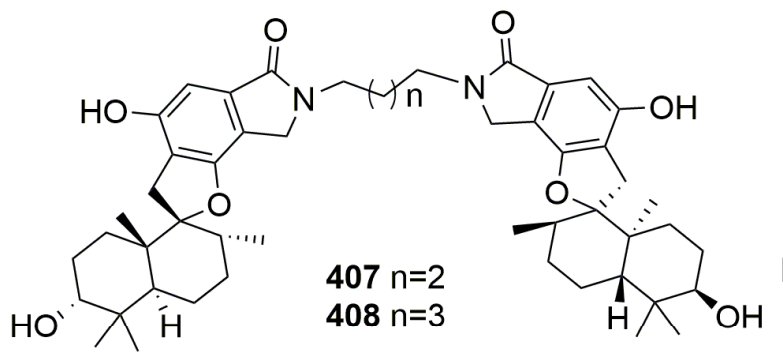

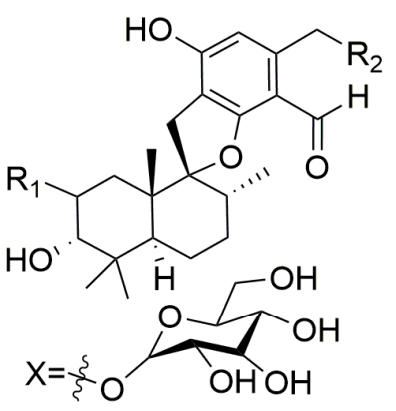<smiles>C[Z11]=CCc1c(O)cc2c(c1OS(=O)(=O)[O-])C[NH+]1CCCCNC1=C2C/C=C(\C)CC/C=C(\C)CCC=C(C)C</smiles>

Figure 23. Chemical structures of diverse new molecules 401-412 isolated from sponge-derived microbes.

\subsubsection{Order Poecilosclerida}

Family Acarnidae

Three novel cytotoxic polyketides, brocaenols A-C (413-415) (Figure 24), were metabolized by a marine-derived fungus Penicillium brocae associated with the Sponge Zyzzya sp. collected in Fiji. All 
three compounds showed moderate to weak cytotoxicity against the HCT-116 cell line with the $\mathrm{IC}_{50}$ values of 20,50 , and $>50 \mu \mathrm{g} / \mathrm{mL}$, respectively [135].

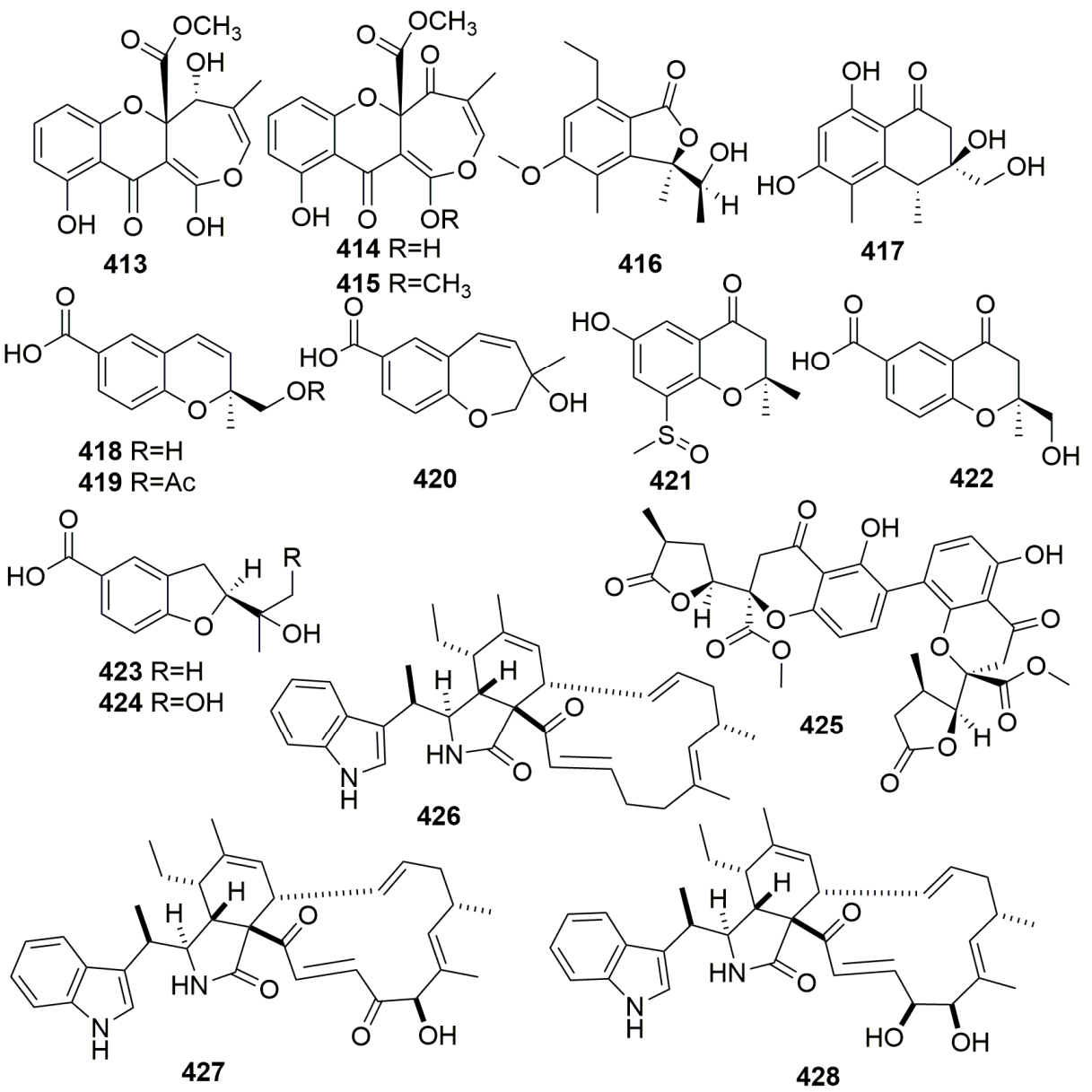

Figure 24. Structures of new marine natural products 413-428 derived from microbes associated with the sponge (Acarnidae and Microcionidae).

Family Microcionidae

Chemical investigation of the marine-derived fungus Neosartorya quadricincta KUFA 0081 led to the isolation of two new pentaketides, including a new benzofuran-1-one derivative (416) and a new isochromen-1-one (417), and seven new benzoic acid derivatives, including two new benzopyran derivatives (418-419), a new benzoxepine derivative (420), two new chromen-4-one derivatives (421-422), and two new benzofuran derivatives (423-424) (Figure 24). The strain KUFA 0081 was isolated from the marine sponge Clathria reinwardti, which was collected in the Gulf of Thailand. None of the isolated compounds exhibited activities in their bioassays [136]. The investigation of the marine sponge Clathria reinwardtii (Thailand)-derived fungus, Neosartorya fennelliae KUFA 0811, yielded a previously unreported dihydrochromone dimer, paecilin E (425) (Figure 24), whose bioassay was disappointing [137]. Three new secondary metabolites, chaetoglobosin-510 (426), -540 (427), and -542 (428) (Figure 24) were isolated from the fungus Phomopsis asparagi cultured from the sponge Rhaphidophlus juniperina (U.S. Virgin Island). Compound $\mathbf{4 2 8}$ displayed antimicrofilament activity and anti-tumor activity toward murine colon and leukemia cancer cell lines [138].

Family Mycalidae

A new compound, (S)-2,4-dihydroxy-1-butyl(4-hydroxy) benzoate (429) (Figure 25), was from the fungus Penicillium auratiogriseum; it was isolated from the sponge Mycale plumose (collected in 
Qingdao, China) and showed potent anti-tumor activity in tsFT210 cells, with a maximum inhibitory effect observed at $8.0 \mu \mathrm{g} / \mathrm{mL}$ [139]. Three new quinazoline alkaloids, aurantiomides A-C (430-432) (Figure 25), were found from the fungus Penicillium aurantiogriseum SP0-19, which isolated from the sponge Mycale plumose collected in Qingdao, China. Compounds 431 and $\mathbf{4 3 2}$ exhibited moderate cytotoxicities against HL-60, P388, and BEL-7402, P388 cell lines [140]. Chemical investigation of the marine sponge-associated bacterium Pseudoalteromonas rubra CMMED 294 obtained from a small piece of sponge, most likely Mycale armata (collected in Kaneohe Bay off Oahu, HI, United States of America), led to the isolation of a 2-Substituted Prodiginine, 2-(p-Hydroxybenzyl) prodigiosin (433) (Figure 25) [141]. A new aspochracin derivative JBIR-15(434) (Figure 25) was from a sponge-derived fungus Aspergillus sclerotionrum Huber Sp080903f04, which was isolated from a sponge Mycale sp., collected from Ishigaki Islang, Japan. Compound $\mathbf{4 3 4}$ did not show any cytotoxic effects in its bioassays [142]. A new diketopiperazine dimer, eurocristatine (435) (Figure 25), was isolated from the fungal strain Eurotium cristatum KUFC 7356; in turn, the fungus was isolated from the marine sponge Mycale sp., which was collected from Thailand. Compound 435 exhibited neither cytotoxic, antibacterial, nor antifungal activity [143]. Chemical analysis of the marine fungus Talaromyces tratensis KUFA 0091 derived from the marine sponge Mycale sp. (Thailand) afforded a new isocoumarin derivative tratenopyrone (436) (Figure 25), whose bioassay was disappointing [123]. Chemical investigation of the marine sponge-associated fungus Neosartorya glabra KUFA 0702, which was obtained from the marine sponge Mycale sp. (Thailand), led to the isolation of two new cyclotetrapeptides, sartoryglabramides A-B (437-438), and a new analog of fellutanine A (439) (Figure 25). None of them exhibited either antibacterial or antifungal activities [144].

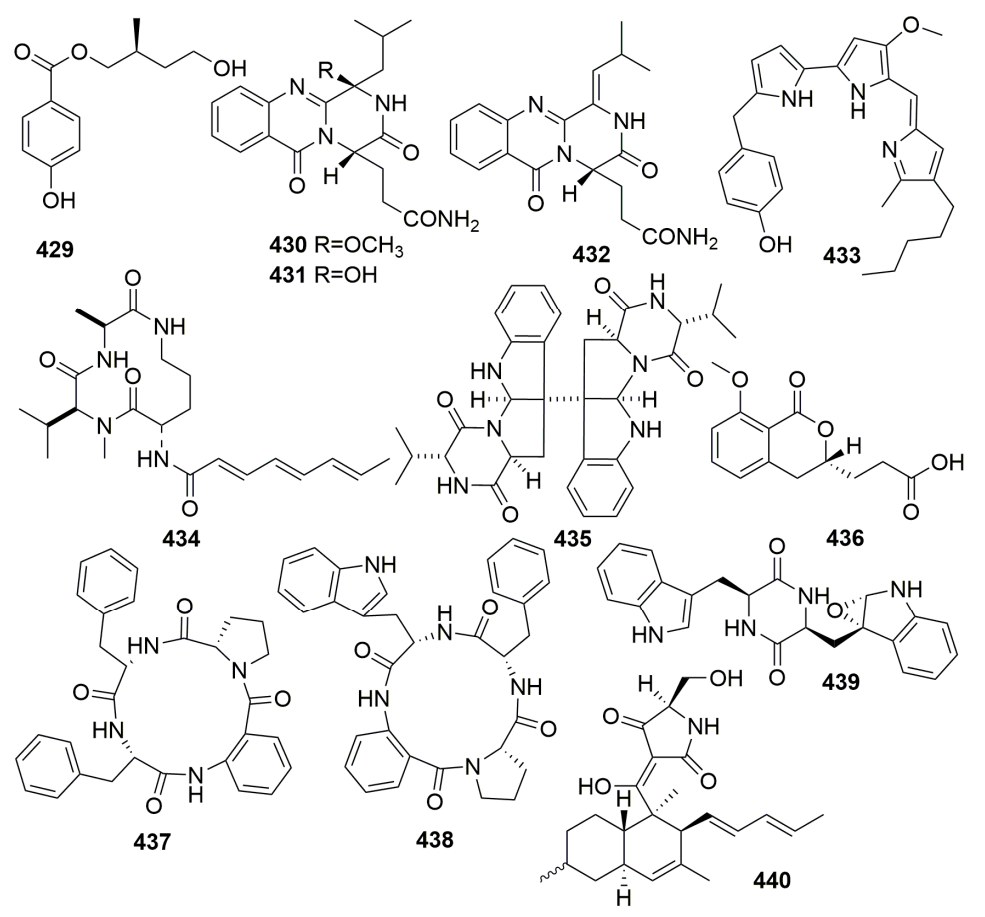

Figure 25. Chemical structures of new molecules 429-440.

Family Myxillidae

A new equisetin-like tetramic acid derivative, beauversetin (440) (Figure 25), was isolated from the sponge-derived fungus Beauveria bassiana; in turn, this was isolated from the sponge Myxilla incrustans, which was collected from the island of Helgoland. Compound 440 exihibited moderate anti-tumor activity against a six-cell line panel for a monolayer assay ( $\left.\mathrm{IC}_{50}, 3.09 \mu \mathrm{g} / \mathrm{mL}\right)$ [145]. 


\subsubsection{Order Scopalinida}

Family Scopalinidae

Chemical investigation of a sponge-derived Streptomyces sp. from the sponge Scopalina ruetzleri (Puerto Rico) led to the isolation of six new angucyclinone derivatives monacyclinones A-F (441-446) (Figure 26). Monacyclinones A-F (441-446) showed potent bioactivity against human rhabdomyosarcoma cancer cells $\left(\mathrm{IC}_{50}, 446,0.73 \mu \mathrm{M}\right)$ and were active against Gram-positive bacteria [146]. From a strain of the marine-derived fungus Aspergillus aculeatus strain CRI322-03 derived from a marine sponge Stylissa flabelliformis (Thailand), three new compounds, pre-aurantiamine (447), (-)-9-hydroxyhexylitaconic acid (448), and (-)-9-hydroxyhexylitaconic acid-4-methyl ester (449) (Figure 26) were isolated [147]. A new ergosterol analog, talarosterone (450), and a new bis-anthraquinone derivative (451) (Figure 26) were isolated from the marine fungus Talaromyces stipitatus KUFA 0207 isolated from the marine sponge Stylissa flabelliformis (Thailand) [148].

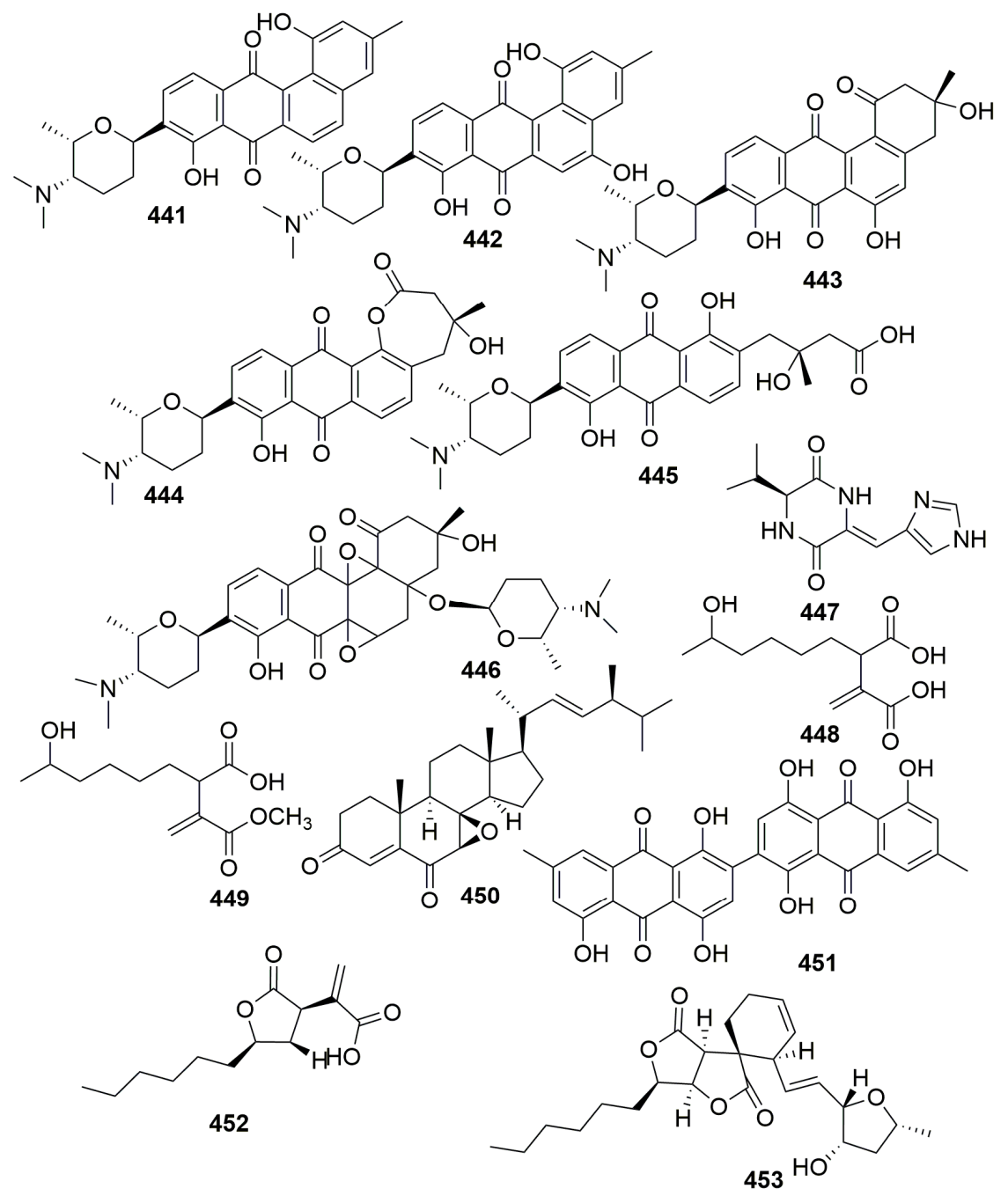

Figure 26. Chemical structures of new marine natural products 441-453.

\subsubsection{Order Sphaerocladina}

From a strain of the fungus Hypoxylon monticulosum CLL-205 derived from a Sphaerocladina sponge collected from the Tahiti coast (France), two sporothriolide-related compounds (452-453) (Figure 26) were isolated. Only compound 452 exhibited moderate cytotoxicity against the HCT-116 cell line with $\mathrm{IC}_{50}$ values of $18 \mu \mathrm{M}$ [149]. 


\subsubsection{Order Suberitida}

Family Halichondriidae

Chemical examination of secondary metabolites produced by the marine sponge-associated fungus Gymnasella dankaliensis (Castellani) Currah OUPS-N134, yielded 11 new compounds, gymnasterones A-B (454-455), gymnastatins D-K (456-463), gymnamide (464), and a structurally unique and cytotoxic steroid (465) (Figure 27), which was designated dankasterone. The strain OUPS-N134 was isolated from the marine sponge Halichondria japonica, which was collected in the Osaka Bay of Japan. Compounds 454-459, 461-463, and 465 exhibited significant to weak cytotoxic activity in the P388 lymphocytic leukemia test system in cell culture with $\mathrm{ED}_{50}$ values ranging from 0.021 to $10.8 \mu \mathrm{g} / \mathrm{mL}$. Furthermore, compounds $\mathbf{4 6 1}$ and $\mathbf{4 6 2}$ showed appreciable growth inhibition against the selected human cancer cell lines [150-154]. Further study on the fungus Gymnacella dankaliensis OUPS-N134 derived from the sponge Halichondria japonica (collected in Japan) afforded six extremely unusual steroids, dankasterones A-B (466-467) and gymnasterones A-D (468-471), and four new metabolites, gymnastatins Q-R (472-473) and dankastatins A-B (474-475) (Figure 28). All the compounds except compound 468 exhibited significant and marginal growth inhibition against the murine $\mathrm{P} 388$ cell line with $\mathrm{ED}_{50}$ values ranging from 0.15 to $2.8 \mu \mathrm{g} / \mathrm{mL}$. Furthermore, compound 472 showed appreciable growth inhibition against the BSY-1 (breast) and MKN7 (stomach) human cancer cell lines [155,156].

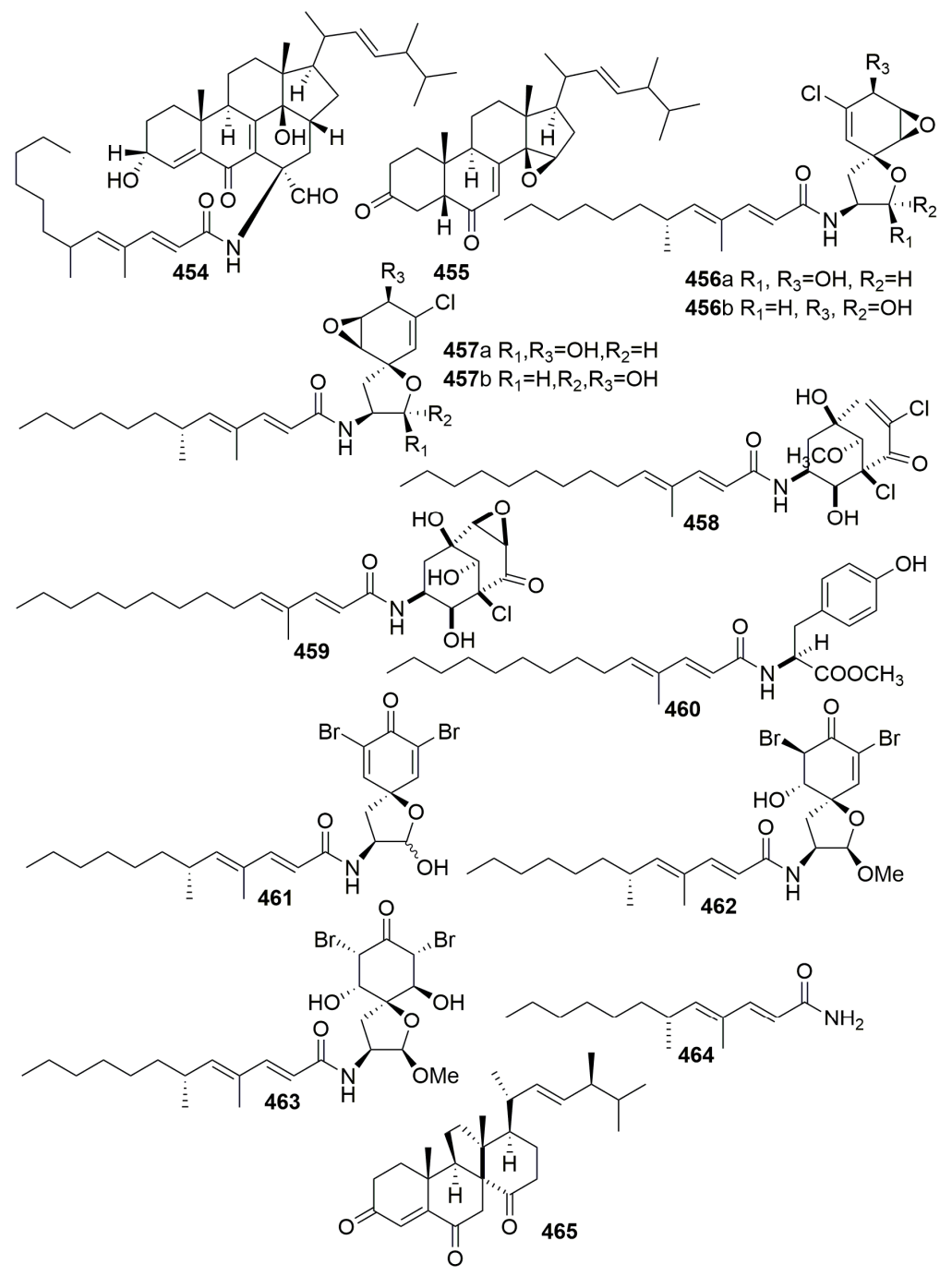

Figure 27. Chemical structures of new compounds 454-465. 


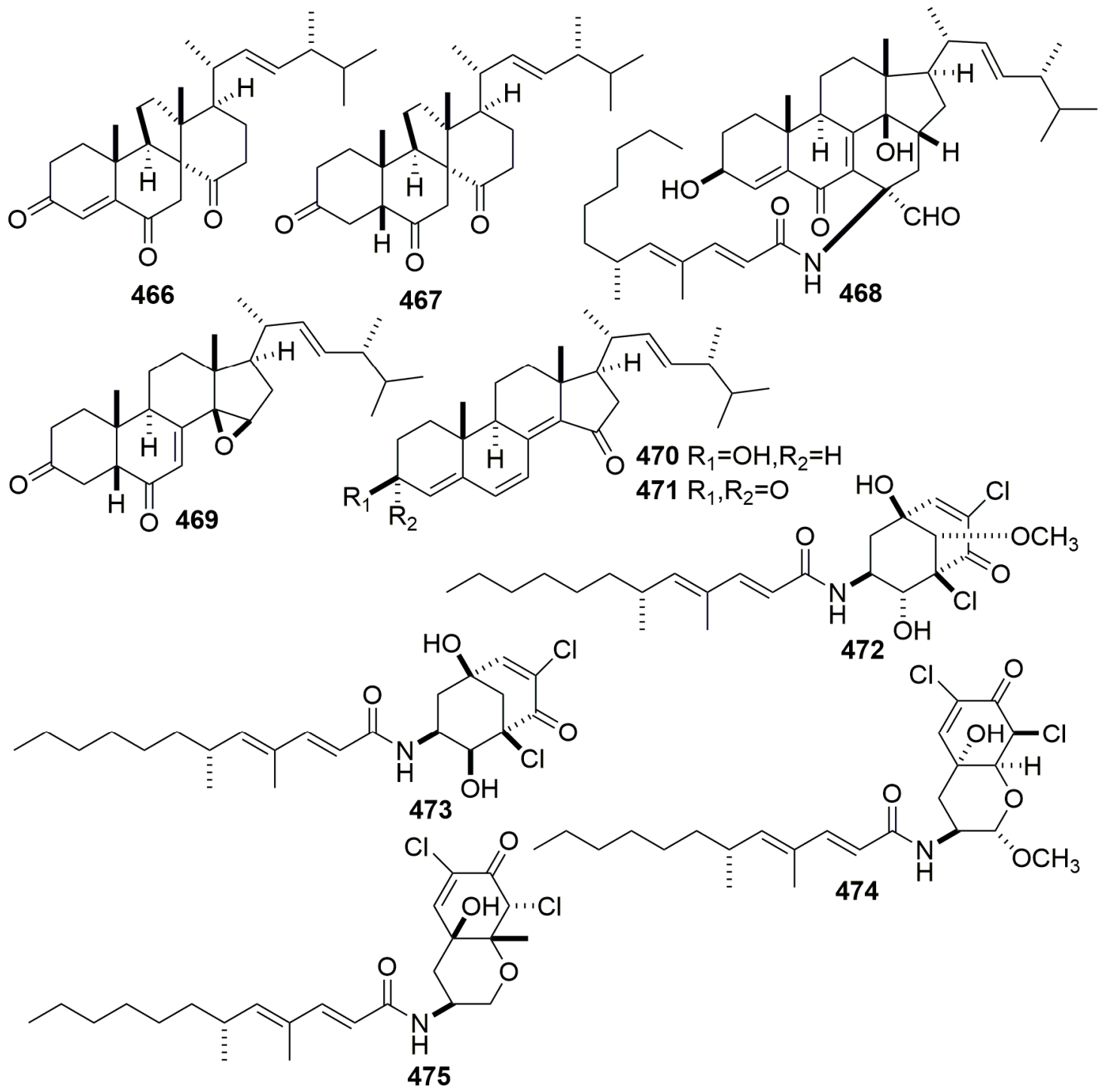

Figure 28. Chemical structures of new compounds 466-475.

Five novel metabolites, trichodenones A-C (476-478) and harzialactone A-B (479-480) (Figure 29), were isolated from Trichoderma harzianum OUPS-N 115 colonizing in the sponge Halichondria okadai, which was collected in the Tanabe Bay of Japan. Compounds 476-478 exhibited significant cytotoxicity against cultured P388 cells with $\mathrm{ED}_{50}$ values of $0.21,1.21$, and $1.45 \mu \mathrm{g} / \mathrm{mL}$, respectively [157]. Four unusual cell-associated glycoglycerolipids (481-484) (Figure 29) were metabolized by a marine-derived bacterium Microbacterium sp. associated with the sponge Halichondria panicea, which was collected along the Adriaticcoast, Rovinj, Croatia [158]. Novel antibiotics, YM-266183 (485) and YM-266184 (486) (Figure 29), were detected in the Bacillus cereus QN03323, which was isolated from the marine sponge Halichondria japonica (collected in Japan). Both compounds were active against Gram-positive bacteria including Methicillin-resistant Staphylococcus aureus (MRSA), Methicillin-resistant Streptococcus epidermidis (MRSE), and vancomycin-resistant Enterococci (VRE) with MIC values ranging from 0.025 to $1.56 \mu \mathrm{g} / \mathrm{mL}$ [159]. Chemical examination of a marine fungus Clonostachys rogersoniana strain HJK9, isolated from a sponge Halicondria japonica (collected in Numazu, Japan), yielded two new anti-dinoflagellates clonostachysins A-B (487-488) (Figure 29). Both compounds exhibited a selectively anti-dinoflagellate against Prorocentrum micans at $30 \mu \mathrm{M}$ [160]. 


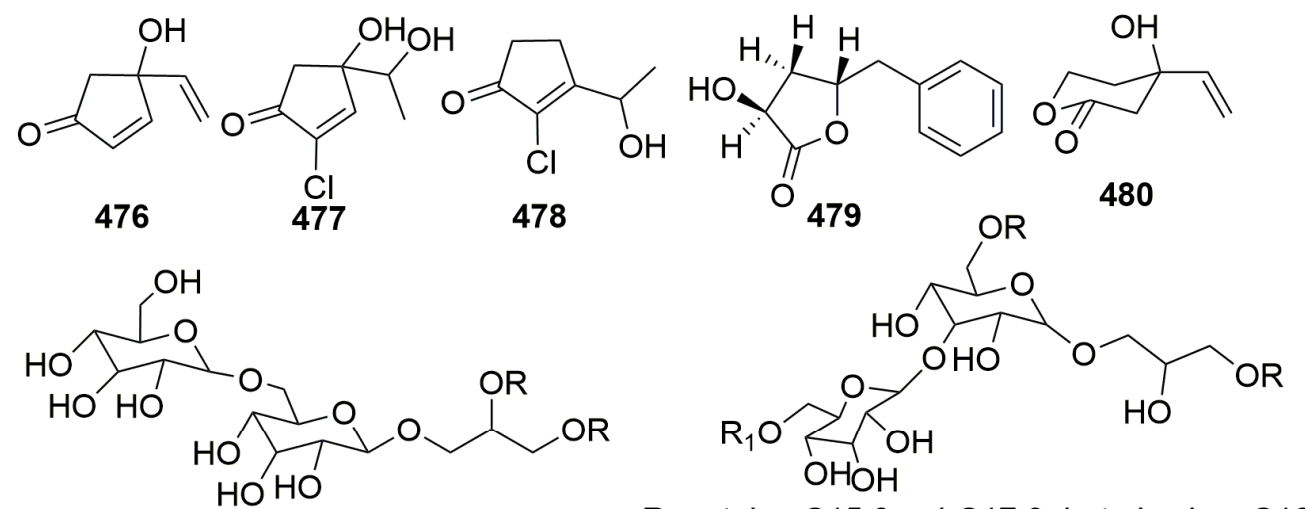

$481 \mathrm{R}=$ anteiso- $\mathrm{C} 15: 0$ and- $\mathrm{C} 17: 0$; but also iso $-\mathrm{C} 16: 0$<smiles>[R]CC([R])COC1OC2OC1C2C(O)CO</smiles>

$484 \mathrm{R}=$ anteiso- $\mathrm{C} 15: 0$ and $-\mathrm{C} 17: 0$; but also iso $-\mathrm{C} 16: 0$

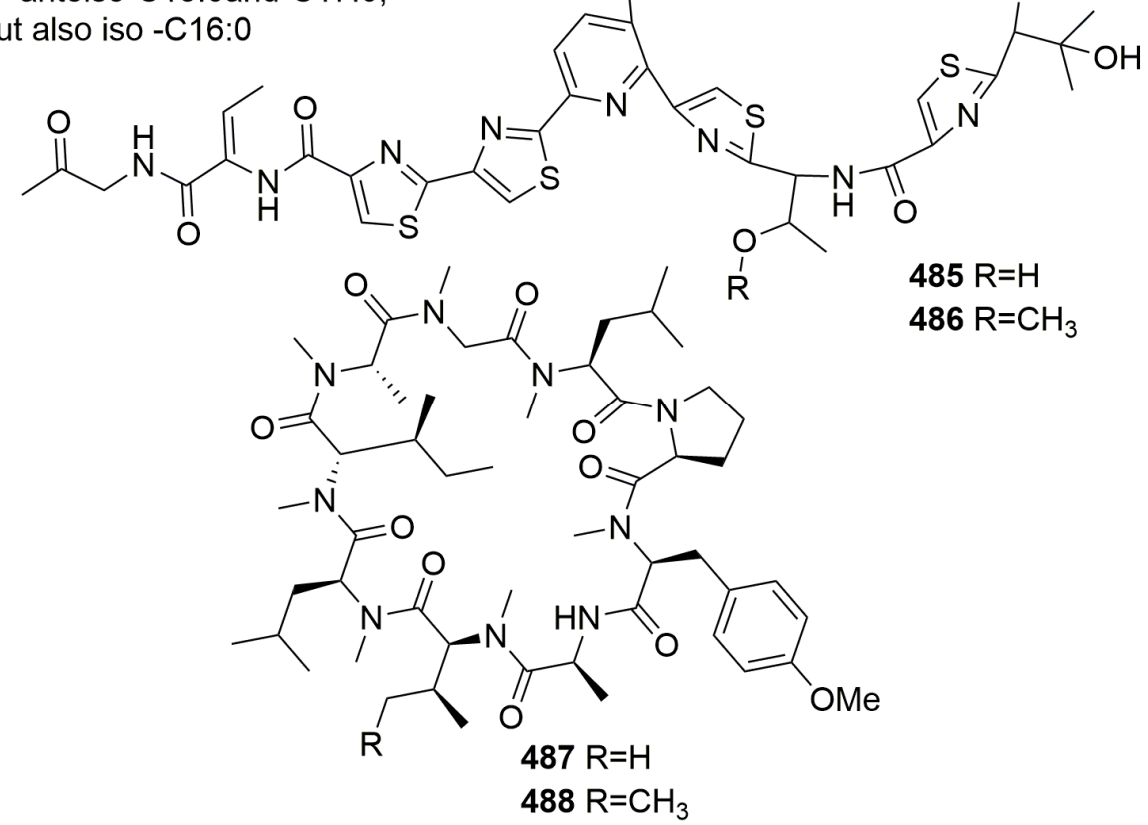

Figure 29. Structures of new molecules 476-488 isolated from the microorganisms.

The investigation of the marine Streptomyces HB202 from the marine sponge Halichondria panacea from the Baltic Sea (Germany) yielded eight new phenazines, streptophenazines A-H (489-496), a new benz[a]anthracene derivative called mayamycin (497), and three new streptophenazines I-K (498-500) (Figure 30). Compound 497 exhibited potent cytotoxic activity against eight human cancer cell lines, and compounds 498-500 showed moderate activities against the enzyme phosphodiesterase PDE 4B with $\mathrm{IC}_{50}$ values of $11.1,12.0$, and $12.2 \mu \mathrm{g} / \mathrm{mL}$, respectively. Compounds $491,496,497,499$, and 500 exhibited moderate antibacterial activity against the selected strains [161-163]. Chemical examination of the fungal strain Exophiala sp. from the marine sponge Halichondria panicea (Korea) afforded two unusual compounds, Chlorohydroaspyrones A-B (501-502) (Figure 30). Both compounds showed weak antibacterial activity [164]. One fungal strain, Pichia membranifaciens USF-HO25, derived from the sponge Halichondria okadai (collected in Japan) was found to produce two new indole derivatives (503-504) (Figure 30), which displayed weak DPPH (2,2-diphenyl-1-picrylhydrazyl) radical scavenging 
activities [165]. Four new $\gamma$-pyrones, nocapyrones A-D (505-508) (Figure 30), were found in an associated actinomycete Nocardiopsis strain HB383 in the marine sponge Halichondria panicea, which was collected from the Baltic Sea (Germany). No bioactivities were detected [166].<smiles>[R]OC(=O)c1cccc2nc3c(C(C([R])O)C([R])O)cccc3nc12</smiles>

489-490 \& 492-496 $\mathrm{R}_{1}=\mathrm{Me}$

$491 \mathrm{R}_{1}=\mathrm{H}$

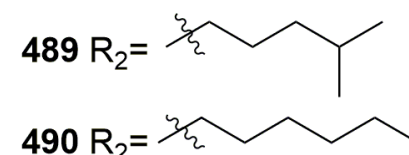

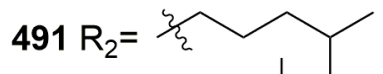<smiles>[R6]#CCCC(C)C</smiles>

$493 R_{2}=$ 年<smiles>[R4]=CCCCCC(C)C</smiles><smiles>[R5]#CCCCCC(C)CC</smiles><smiles></smiles><smiles>COC(=O)OC</smiles><smiles>CN[C@H]1C[C@@H](c2c(O)c3c(c4c(O)cc(C)cc24)C(=O)c2cccc(O)c2C3=O)O[C@@H]1C</smiles><smiles>COC(=O)OC</smiles><smiles></smiles><smiles>c1ccc2nc3ccccc3nc2c1</smiles><smiles>COCOC</smiles>
498<smiles>C[C@H](O)[C@H](Cl)C1=C[C@@H](O)[C@@H](C)OC1=O</smiles><smiles>CCC(C)CCC[C@H](C)[C@H](O)c1cccc2nc3c(C(=O)O)cccc3nc12</smiles>

500<smiles>[R]C(C)(CCCC)C([R])(O)O[C@H]1OC(C)=C[C@H](O)[C@H]1C</smiles><smiles>[R]C(C)C(C)CCCCc1oc(OC)c(C)c(=O)c1C(=O)O</smiles><smiles>[R][R9](=O)O</smiles>
$508 \mathrm{R}==\mathrm{O}$

Figure 30. Chemical structures of compounds 489-508.

A fungal strain of Trichoderma harzianum OUPS-111D-4 from the marine sponge Halichondria okadai yielded six novel decalin derivatives, Tandyukisins A-F (509-514), and three new compounds, trichodermanins C-E (515-517) (Figure 31). Compounds 513-515 exhibited significant cytotoxicity against the cancer cell lines P388, HL-60, and L1210 leukemia cell lines with $\mathrm{IC}_{50}$ values ranging from 3.8 to $7.9 \mu \mathrm{M}$, respectively [167-170]. An unusual polyketide with a new carbon skeleton, lindgomycin (518) (Figure 31), was metabolized by a marine fungus of Lindgomycetaceae strain LF327 isolated from the sponge Halichondria panicea (Germany) and showed antibiotic activities with $\mathrm{IC}_{50}$ value of $5.1 \pm 0.2 \mu \mathrm{M}$ against methicillin-resistant Staphylococcus aureus [171]. 


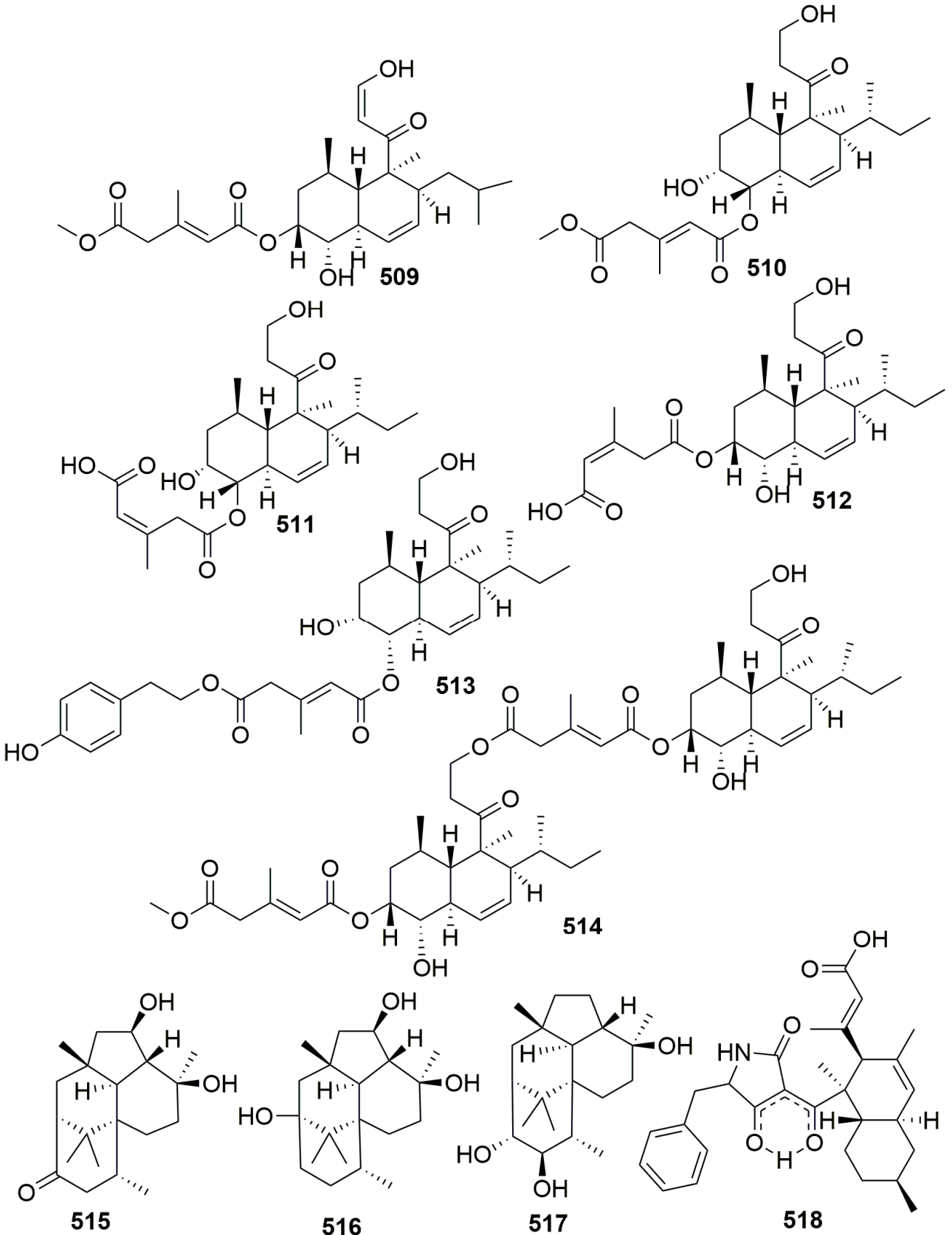

Figure 31. Structures of new marine natural products 509-518.

Chemical investigation of an associated actinomycete Streptomyces microflavus, which was obtained from the sponge Hymeniacidon perlevis (collected from Dalian, China), led to the isolation of one new nucleoside derivative named 3-acetyl-5-methyl-2'-deoxyuridine (519) (Figure 32) [172]. From the sponge Hymeniacidon sp. (East China Sea), an actinomycete Streptomyces carnosus strain AZS17 was isolated and shown to produce two novel kijanimicin derivatives named lobophorin C-D (520-521) (Figure 32). Lobophorin $C$ displayed potent cytotoxic activity against the human liver cancer cell line 7402 with an $\mathrm{IC}_{50}$ value of $0.6 \mu \mathrm{g} / \mathrm{mL}$, while lobophorin D showed significant inhibitory effect on human breast cancer cells MDA-MB 435 with an $\mathrm{IC}_{50}$ value of $7.5 \mu \mathrm{M}$ [173]. A marine sponge-derived fungus strain Aspergillus versicolor MF359 isolated from a marine sponge of Hymeniacidon perleve (collected from the Bohai Sea, China) afforded three new secondary metabolites, named hemiacetal sterigmatocystin (522), acyl-hemiacetal sterigmatocystin (523), and 5-methoxydihydrosterigmatocystin (524) (Figure 32). Compound 524 showed activity against S. aureus and B. subtilis with MIC values of 12.5 
and $3.125 \mu \mathrm{g} / \mathrm{mL}$, respectively [174]. From the sponge Hymeniacidon perleve (collected from the Bohai Sea, China), fungus Aspergillus versicolor Hmp-F48, a new dibenzo [1,4] dioxin 525, and two new prenylated diphenyl ethers 526-527 (Figure 32) were identified and found to show potent cell growth inhibitory activities against the HL-60 cell line with $\mathrm{IC}_{50}$ values of 3.26, 6.35, and $19.97 \mu \mathrm{M}$, respectively [175]. Chemical examination of the fungal strain Pseudogymnoascus sp. F09-T18-1, which is associated with an Antarctic marine sponge belonging to the genus Hymeniacidon, yielded four new nitroasterric acid derivatives, pseudogymnoascins A-C (528-530) and 3-nitroasterric acid (531) (Figure 32), which were inactive against a panel of bacteria and fungi [176]. A new minor diketopiperazine alkaloid (532) and a natural lactone (533) (Figure 32) were detected in the sponge-derived fungus Simplicillium sp. YZ-11 originally separated from the marine sponge Hymeniacidon perleve collected from Dalian, China [177]. Chemical analysis of the fungus Trichoderma sp. HPQJ-34 isolated from the marine sponge Hymeniacidon perleve (Zhejiang, China) afforded a new cyclopentenone, 5-hydroxycyclopenicillone (534) (Figure 32). Compound 534 has moderate antioxidative, anti-A $\beta$ fibrillization activities, and neuroprotective effects, and it might be a good free radical scavenger [178].

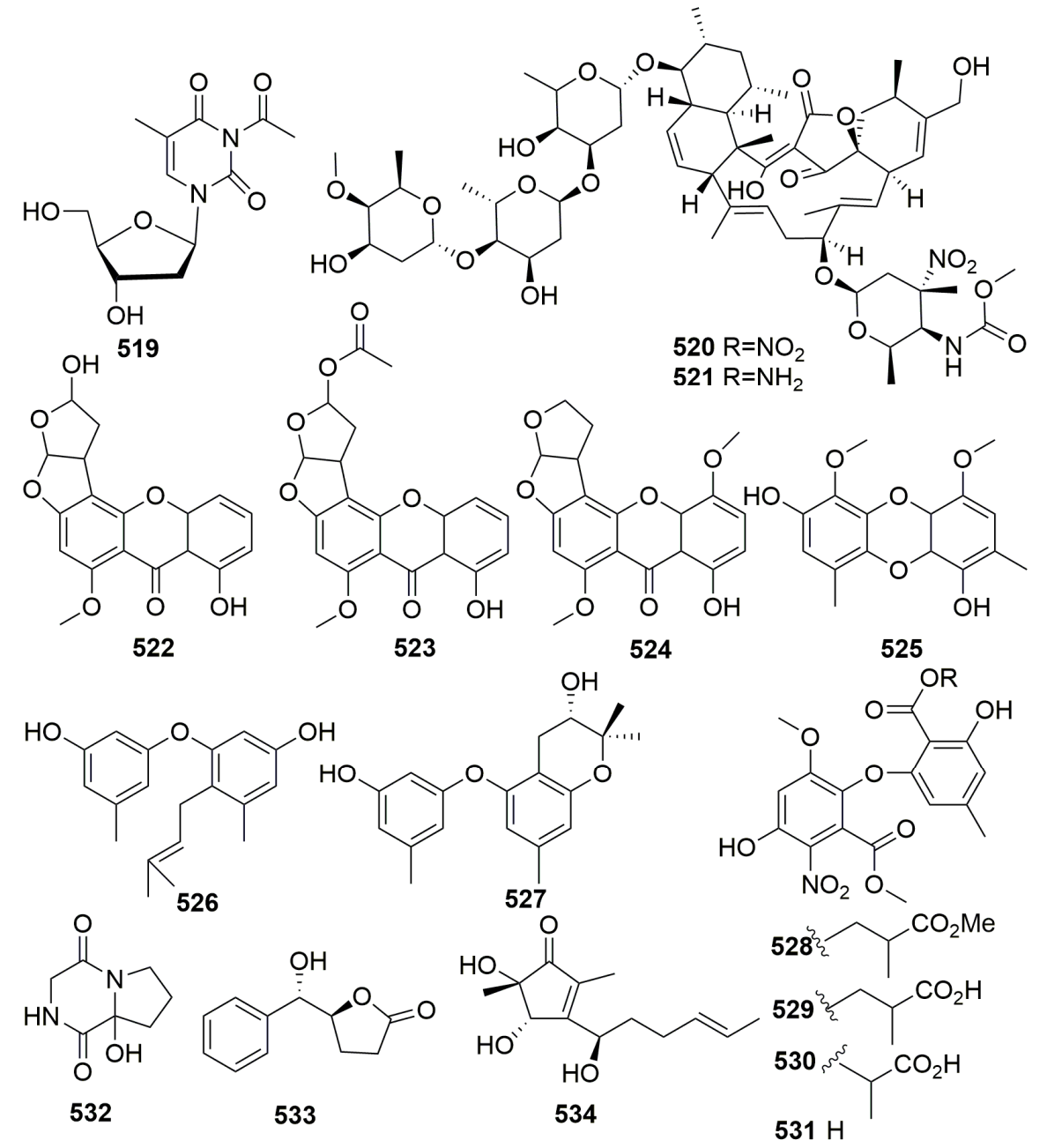

Figure 32. Chemical structures of diverse new molecules 519-534.

Family Suberitidae

Two new cyclic peptides, cyclo-(glycyl-L-seryl-L-prolyl-L-glutamyl) and cyclo-(glycyl-L-prolylL-glutamyl) (535-536) (Figure 33), were produced by a Ruegeria strain cultured from the Sponge Suberites domuncula. Both compounds showed moderate activity against Bacillus subtilis [179]. One fungal strain, Aspergillus ustus, derived from the sponge Suberites domuncula (collected from the Adriatic 
Sea) was found to produce seven new drimane sesquiterpenoids (537-543), five new ophiobolin-type sesterterpenoids (544-548), and the two new pyrrolidine alkaloids (549-550) (Figure 33). Compound 540 showed moderate cytotoxic activity against L5178Y with an $\mathrm{EC}_{50}$ value of $5.3 \mu \mathrm{g} / \mathrm{mL}$, while compound 541 showed significant cytotoxic activity against L5178Y, HeLa, and PC12 cells with EC 50 values of $0.6,5.9$, and $7.2 \mu \mathrm{g} / \mathrm{mL}$, respectively $[180,181]$. Three new compounds, bendigoles D-F (551-553) (Figure 33), were produced by a strain of bacterium, Actinomadura sp. SBMs009, a symbiont on the marine sponge Suberites japonicus. Compound 551 was the most active inhibitor of GR-translocation (GR: glucocorticoid receptor) and exhibited cytotoxicity against the L929 (mouse fibroblast) cell line with an $\mathrm{IC}_{50}$ value approximated to $30 \mu \mathrm{M}$, while compound 553 was the most effective inhibitor of $\mathrm{NF}-\mathrm{kB}$ nuclear translocation with an $\mathrm{IC}_{50}$ value of $71 \mu \mathrm{M}$ [182]. Two new benzophenones, acredinones A-B (554-555) (Figure 33), were characterized from a marine-sponge-associated Acremonium sp. F9A015 fungus, associated with a marine sponge Suberites japonicas (Korea). Compounds 554-555 inhibited the outward $\mathrm{K}^{+}$currents of the insulin secreting cell line INS- 1 with $\mathrm{IC}_{50}$ values of 0.59 and $1.0 \mu \mathrm{M}$, respectively [183].

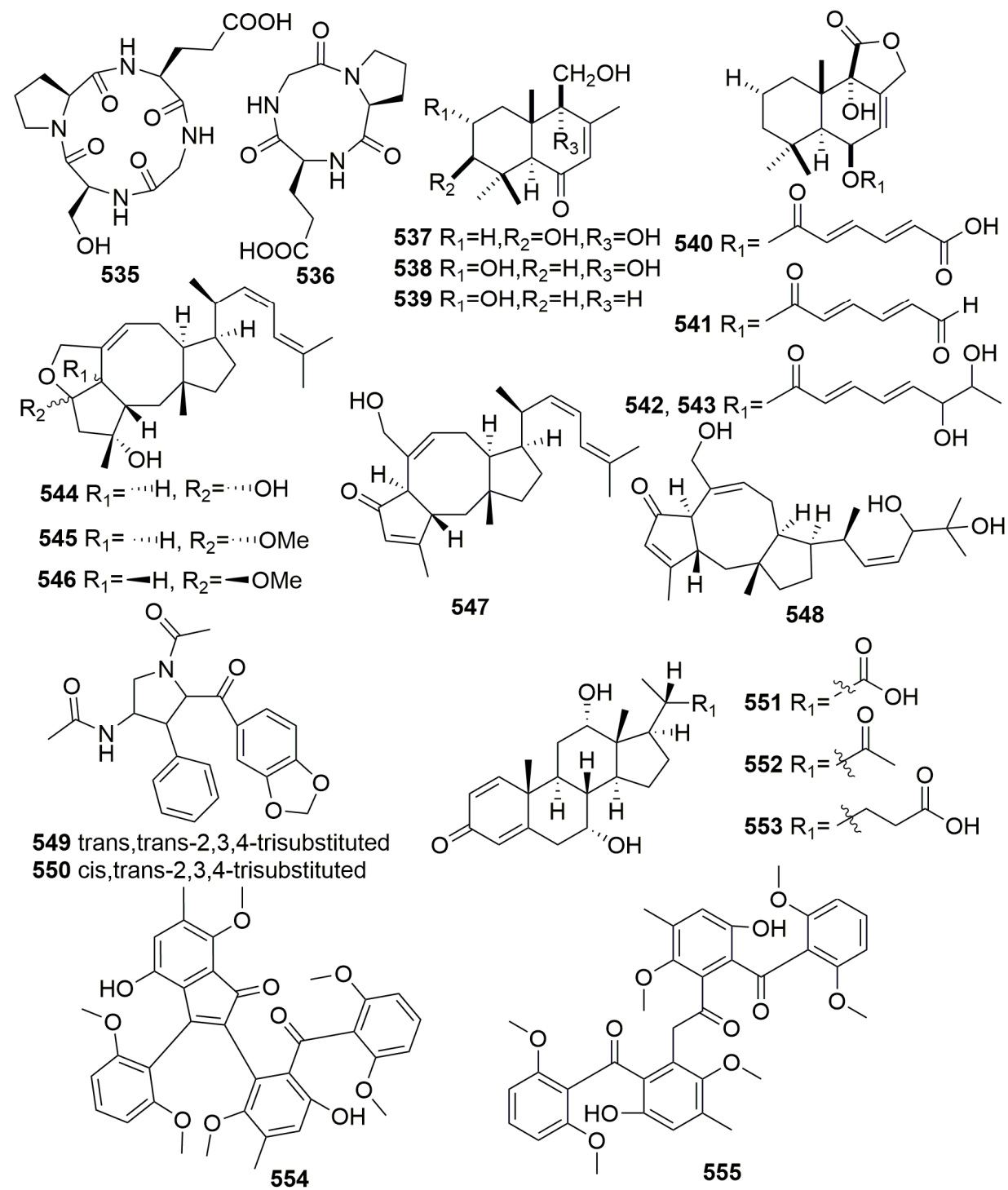

Figure 33. Chemical structures of compounds 535-555. 


\subsubsection{Order Tethyida}

Family Tethyidae

A fungal strain, Scopulariopsis brevicaulis, was obtained from the marine sponge Tethya aurantium (collected in Croatia), and it was found to produce two novel cyclodepsipeptides, scopularides A-B (556-557) (Figure 34). Both compounds exhibited significant activity against several tumor cell lines at $10 \mu \mathrm{g} / \mathrm{mL}$ [184]. The new metabolite cillifuranone (558) (Figure 34) was isolated from the culture broth of Penicillium chrysogenum strain LF066 collected from the Mediterranean marine sponge Tethya aurantium. Compound 558 exhibited weak antibiotic bioactivities [185]. Chemical analysis of the marine fungus Bartalinia robillardoides strain LF550 derived from the Mediterranean sponge Tethya aurantium afforded three new chloroazaphilones-helicusin E (559), isochromophilone X (560), and isochromophilone XI (561)—and one new pentaketide, bartanolide (562) (Figure 34). 561 revealed specifically weak activity against T. rubrum [186]. Chemical investigation of a marine-derived fungus Aspergillus sp. from the marine sponge Tethya aurantium (collected from the Adriatic Sea) led to the isolation of a new tryptophan-derived alkaloid and a new meroterpenoid, austalide R (563-564) (Figure 34). Compound 563 selectively inhibited Vibrio species, and compound 564 showed a broad spectrum of antibacterial activity with MIC values between 0.01 and $0.1 \mu \mathrm{g} / \mathrm{mL}$ [187].

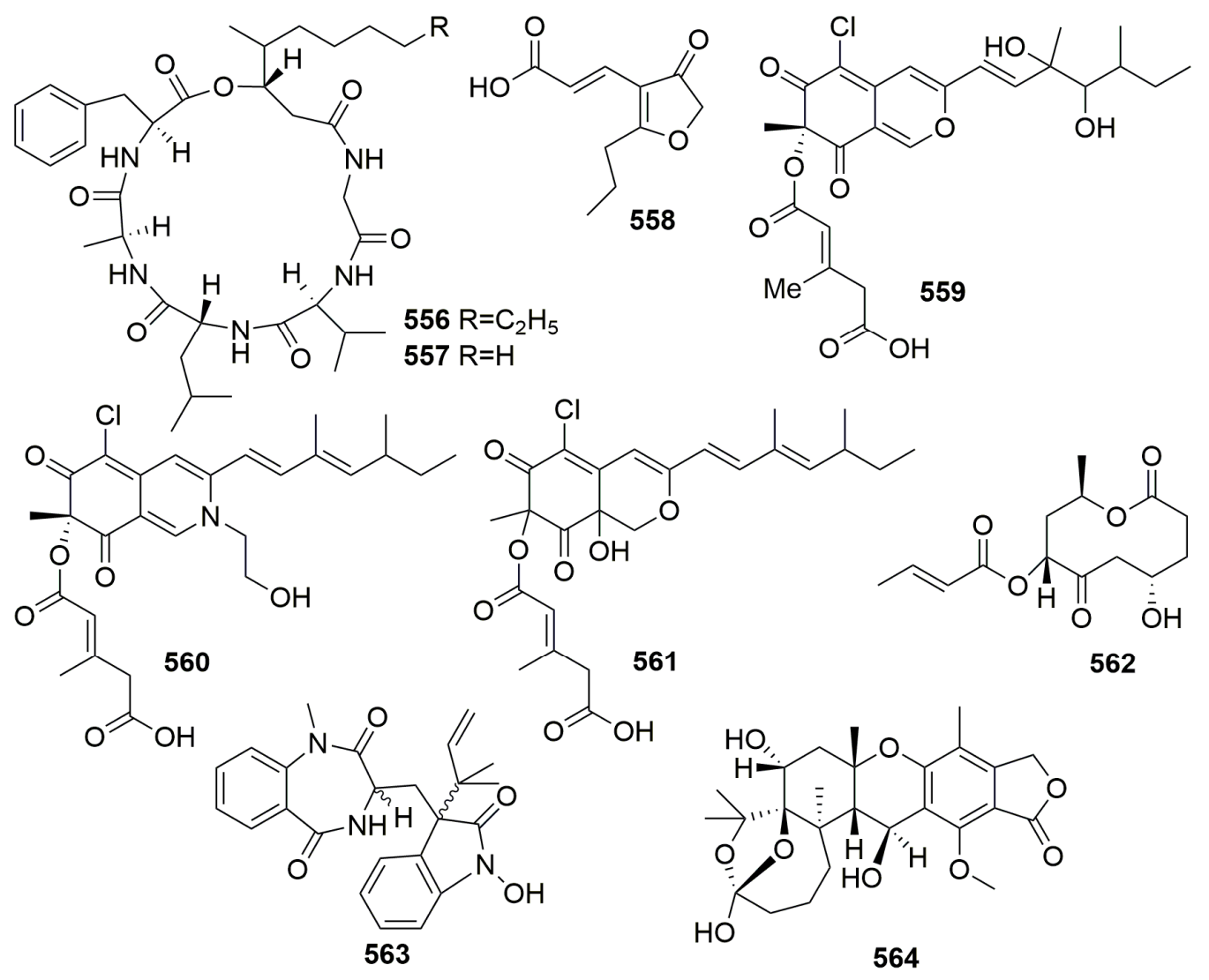

Figure 34. Structures of new marine natural products 556-564 derived from microbes associated with the sponge (Tethyidae).

\subsubsection{Order Tetractinellida}

Off the coast of Korea, a Choristida sponge-derived fungus, Acremonium strictum, yielded a novel natural product acremostrictin (565) and a novel modified base, acremolin (566) (Figure 35). Compound 565 exhibited weak antibacterial and moderate antioxidant activities $\left(\mathrm{IC}_{50}, 2.1 \mathrm{mM}\right)$, and compound 566 exhibited weak cytotoxicity against an A549 cell line with an IC 50 of $45.90 \mu \mathrm{g} / \mathrm{mL}[188,189]$. 


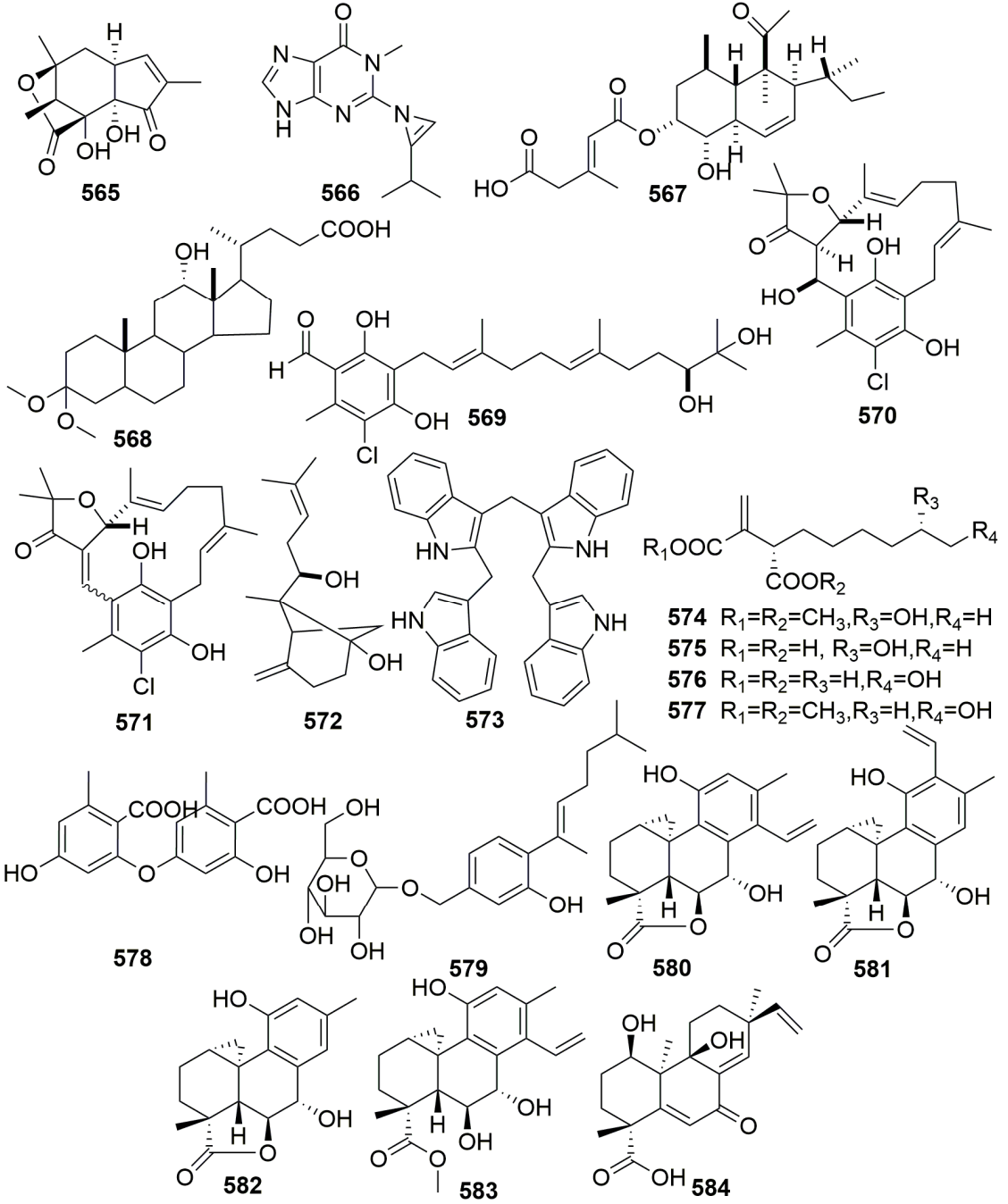

Figure 35. Structures of new compounds 565-584.

Family Ancorinidae

A new polyketide, deoxynortrichoharzin (567) (Figure 35), was produced by the marine-derived fungus Paecilomyces cf. javanica, which is a symbiont on the sponge Jaspis cf. coriacea (collected in the Fiji Islands). Compound 567 did not show any activity in solid-tumor cells in culture [190]. A new bile acid derivative (568) (Figure 35) was metabolized by a marine sponge-associated bacterium Psychrobacter sp. associated with the marine sponge Stelletta sp., which was collected off the coast of Geoje Island, Korea. Compound 568 exhibited moderate suppressive effects on both NO and interleukin-6 (IL-6) production at a concentration of $87.3 \mu \mathrm{g} / \mathrm{mL}$ [191]. New sesquiterpenoids (569-572) (Figure 35) were isolated from the fungal strain Acremonium sp., which was isolated from a marine sponge Stelletta sp. (collected in Korea). Compound 569 exhibited weak anti-inflammatory activity in RAW 264.7 murine macrophage cells [192]. A bacterial strain J05B1-11, isolated from the marine sponge Stelletta sp. (Korea), yielded a new natural product: Sym-Tetra (573) (Figure 35). Compound 573 was non-cytotoxic according to this study [193]. Four new hexylitaconic acid derivatives (574-577) (Figure 35) were isolated from a sponge-derived fungus Penicillium sp., which was isolated from a sponge Stelletta sp. collected in Jeju island, Korea [194]. The investigation of the fungus Aspergillus sydowii from the sponge Stelletta sp. yielded two new metabolites, diorcinolic acid (578) and $\beta$-D-glucopyranosyl aspergillusene A (579) (Figure 35). Compounds 578-579 showed mild cytotoxicity against several human cancer cells with $\mathrm{IC}_{50}$ values ranging from 50 to $70 \mu \mathrm{M}$ [195]. 


\section{Family Geodiidae}

A marine strain of the fungus Arthrinium sp. derived from the Mediterranean sponge Geodia cydonium was found to metabolize five new diterpenoids, arthrinins A-D (580-583) and myrocin D (584) (Figure 35). Myrocin D (584) inhibited vascular endothelial growth factor A (VEGF-A)-dependent endothelial cell sprouting with $\mathrm{IC}_{50}$ values of $2.6 \mu \mathrm{M}$ [196].

\section{Family Neopeltidae}

Four quinolone derivatives, 585-588 (Figure 36), were isolated from a bacterial strain Pseudomonas 1531-E7 associated with the sponge Homophymia sp. collected from New Caledonia. Compound 585 was active against Plasmodium falciparum and against HIV-1 with $\mathrm{ID}_{50}$ values of 1 and $10^{-3} \mu \mathrm{g} / \mathrm{mL}$, respectively. Compound 586 exhibited mild cytotoxicity against $\mathrm{KB}$ cells $\left(\mathrm{IC}_{50}, 5 \mu \mathrm{g} / \mathrm{mL}\right.$ ) and was active against Plasmodium falciparum ( $\mathrm{ID}_{50}, 3.4 \mu \mathrm{g} / \mathrm{mL}$ ). Compound 587 was active against Plasmodium falciparum with an $\mathrm{ID}_{50}$ value of $4.8 \mu \mathrm{g} / \mathrm{mL}$. Compound 588 showed antimicrobial activity against $S$. aureus and cytotoxicity toward KB cells with an $\mathrm{IC}_{50}$ value less than $2 \mu \mathrm{g} / \mathrm{mL}$ [197].

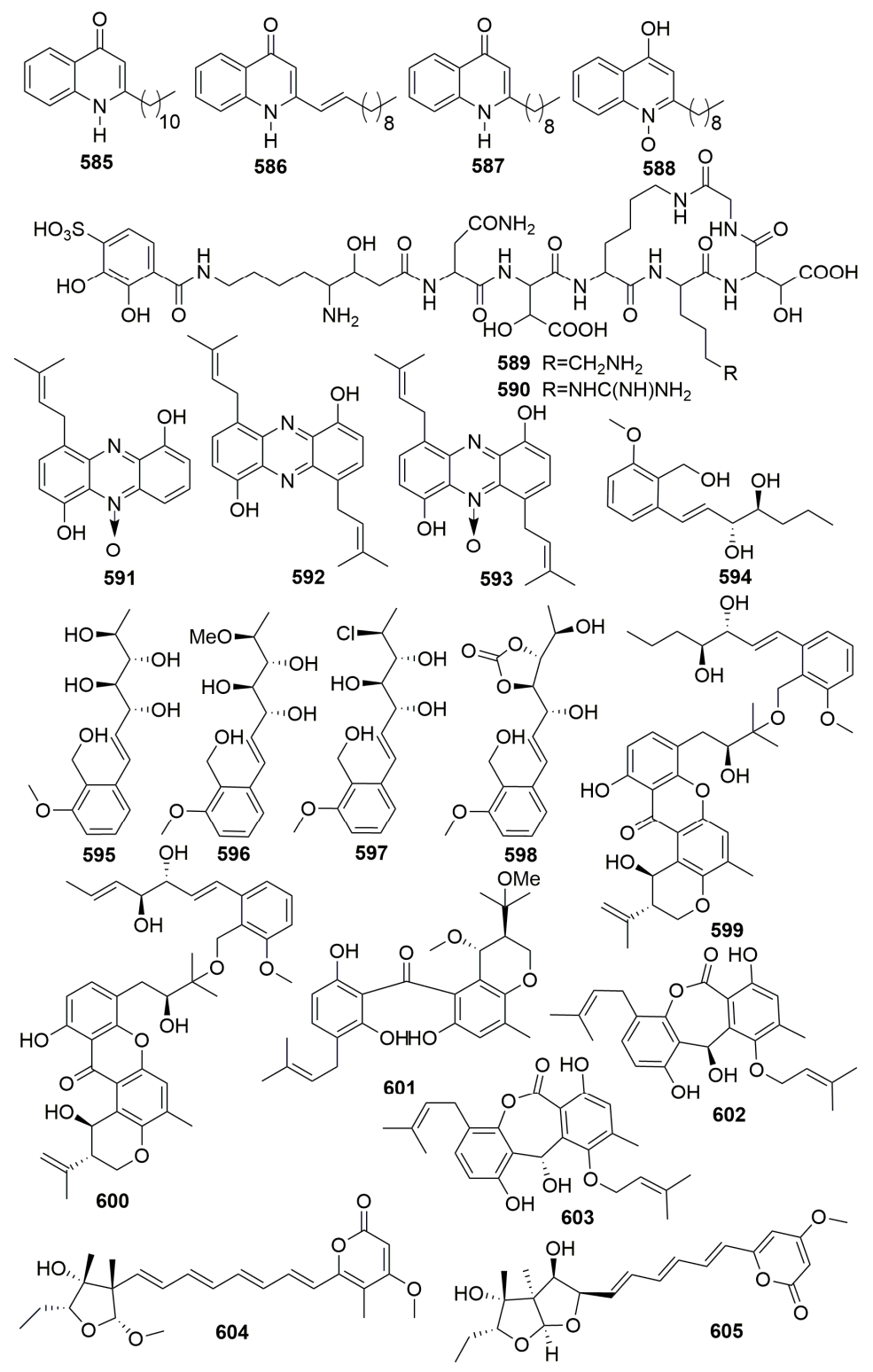

Figure 36. Structures of new marine natural products 585-605 derived from microbes associated with the sponge (Neopeltidae and Tetillidae). 
Family Tetillidae

Pseudoalterobactin A-B (589-590) (Figure 36) were detected in the marine bacterium Pseudoalteromonas sp. KP20-4 originally separated from a marine sponge (Cinachyrella australiensis) obtained in the Republic of Palau [198]. Three novel isoprenoids, JBIR 46-48 (591-593) (Figure 36), were isolated from an actinomycetic strain Streptomyces sp. SpC080624SC-11, which was associated with the marine sponge Cinachyra sp. (Japan) [199]. From a fungal strain Emericella variecolor XSA-07-2 derived from a marine sponge Cinachyrella sp. (the South China Sea), seven new polyketide derivatives, namely, varioxiranols A-G (594-600) (Figure 36), a new hybrid PKS-isoprenoid metabolite (601) (Figure 36), four new lactones-namely, varioxiranols I-L (602-605) (Figure 36), and three novel asteltoxin-bearing dimers-namely, diasteltoxins A-C (606-608) (Figure 37)—were isolated. Three structurally novel asteltoxin-bearing dimers were characteristic of a [2+2] cycloaddition of asteltoxin in different manners. Compounds 594, 602-605, and 606-608 showed weak to moderate cytotoxic activity against the selected tumor cell lines [200-202]. Chemical investigation of the marine-derived Streptomyces sp. DA22 led to the isolation of a new indole alkaloid, streptomycindole (609) (Figure 37). The strain was isolated from the South China Sea sponge Craniella australiensis. Compound 609 showed no cytotoxicity against several selected tumor cell lines [203].

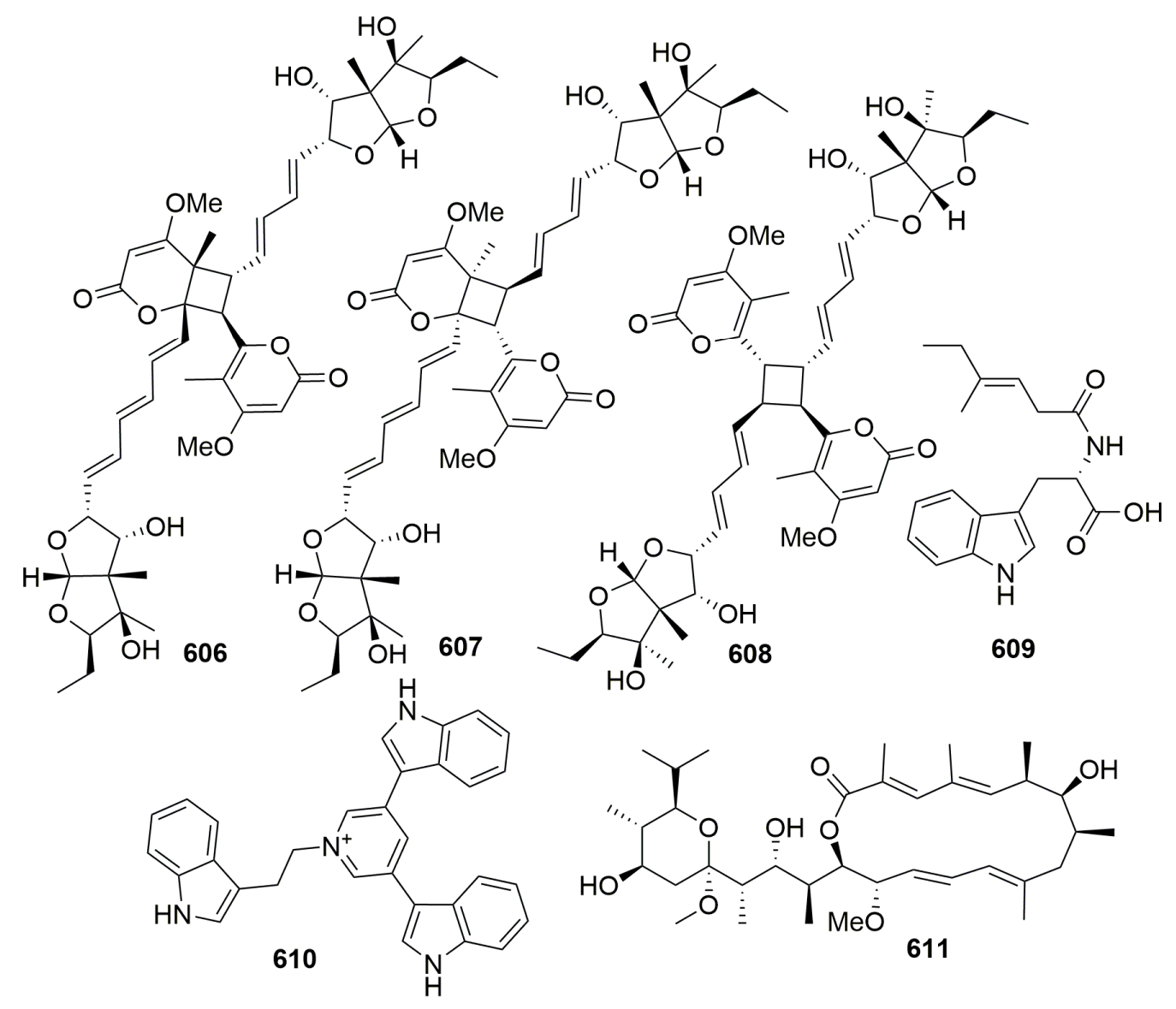

Figure 37. Structures of new marine natural products 606-611 derived from microbes associated with the sponge (Tetillidae and Theonellidae). 
Family Theonellidae

Chemical examination of a marine-derived Escherichia coli from the sponge Discodermia calyx (collected in Japan) afforded a novel pyridinium with three indole moieties: tricepyridinium $\mathbf{6 1 0}$ (Figure 37). 610 showed antimicrobial activity against B. cereus, S. aureus, and C. albicans (with MIC values of $0.78,1.56$, and $12.5 \mu \mathrm{g} / \mathrm{mL}$, respectively) and cytotoxicity to P388 cells with an $\mathrm{IC}_{50}$ value of $0.53 \mu \mathrm{g} / \mathrm{mL}$ [204]. Study on the metabolites of the sponge-derived Streptomyces sp. GIC10-1 derived from the sponge Theonella sp. (Taiwan) afforded a new 16-membered diene macrolide: bafilomycin $\mathrm{M}$ (611) (Figure 37). Compound 611 exhibited significant cytotoxicity toward K-562, HL-60, SUPT-1, and LNCaP tumor cells with $\mathrm{IC}_{50}$ values of $0.060,0.011,0.047$, and $0.389 \mu \mathrm{g} / \mathrm{mL}$, respectively [205].

\subsubsection{Order Verongiida}

Family Aplysinidae

Two new betaenone derivatives (612-613), three new 1,3,6,8-tetrahydroxyanthraquinone congeners (614-616), and two new metabolites, microsphaerones A-B (617-618) (Figure 38) were isolated from an undescribed fungus of the genus Microsphaeropsis, which was isolated from the Mediterranean sponge Aplysina aerophoba. Compounds $\mathbf{6 1 2}$ and 614-616 are inhibitors of protein kinase C (PKC)- $\varepsilon$, the cyclin-dependent kinase 4 (CDK4), and the epidermal growth factor receptor (EGF-R) tyrosine kinases with $\mathrm{IC}_{50}$ values ranging from 18.5 to $54.0 \mu \mathrm{M}[206,207]$. A new compound named hortein (619) (Figure 38) was isolated from the fungus Hortaea werneckii isolated from the Mediterranean sponge Aplysina aerophoba. When tested for antibiotic or insecticidal activity, the bioassays were disappointing [208]. The strain of the fungus Cladosporium herbarum, isolated from the sponges Aplysina aerophoba collected in the Mediterranean Sea, yielded two new R-pyrones, herbarin A-B (620-621) (Figure 38). Compounds $\mathbf{6 2 0}$ and $\mathbf{6 2 1}$ showed activity against Artemia salina but exhibited no significant antibiotic activity [79]. A new glutarimide (622) (Figure 38) was isolated from a marine-derived Streptomyces anulatus S71 isolated from a marine sponge Aplysina aerophoba (South China Sea) [209].

Family Ianthellidae

Six new acremine metabolites, 5-chloroacremine A (623), 5-chloroacremine $\mathrm{H}$ (624), and acremines $\mathrm{O}-\mathrm{R}$ (625-628) (Figure 38), were isolated from a marine-derived fungus Acremonium persicinum, which was isolated from the sponge Anomoianthella rubra collected from Mooloolaba, QLD [210]. Chemical study of an unidentifiable sponge-derived fungus from an Ianthella sponge (Papua New Guinea) afforded two novel cyclic depsipeptides, guangomides A-B (629-630), together with a new destruxin derivative (631) (Figure 38). Compounds 629 and 630 exhibited weak antibacterial activity against Staphylococcus epidermidis and Enterococcus durans [211].

\section{Family Pseudoceratinidae}

New compounds termed JBIR 97-99 (632-634) (Figure 38) were isolated from the culture of Tritirachium sp. SpB081112MEf2 associated with the marine sponge, Pseudoceratina purpurea, collected from Okinawa Prefecture, Japan. Compounds 632-634 showed cytotoxic effects against HeLa cells ( $\mathrm{IC}_{50}$, 11,17 , and $17 \mu \mathrm{M}$, respectively) and ACC-MESO-1 cells ( $\mathrm{IC}_{50}, 31,63$, and $59 \mu \mathrm{M}$, respectively) [212]. 


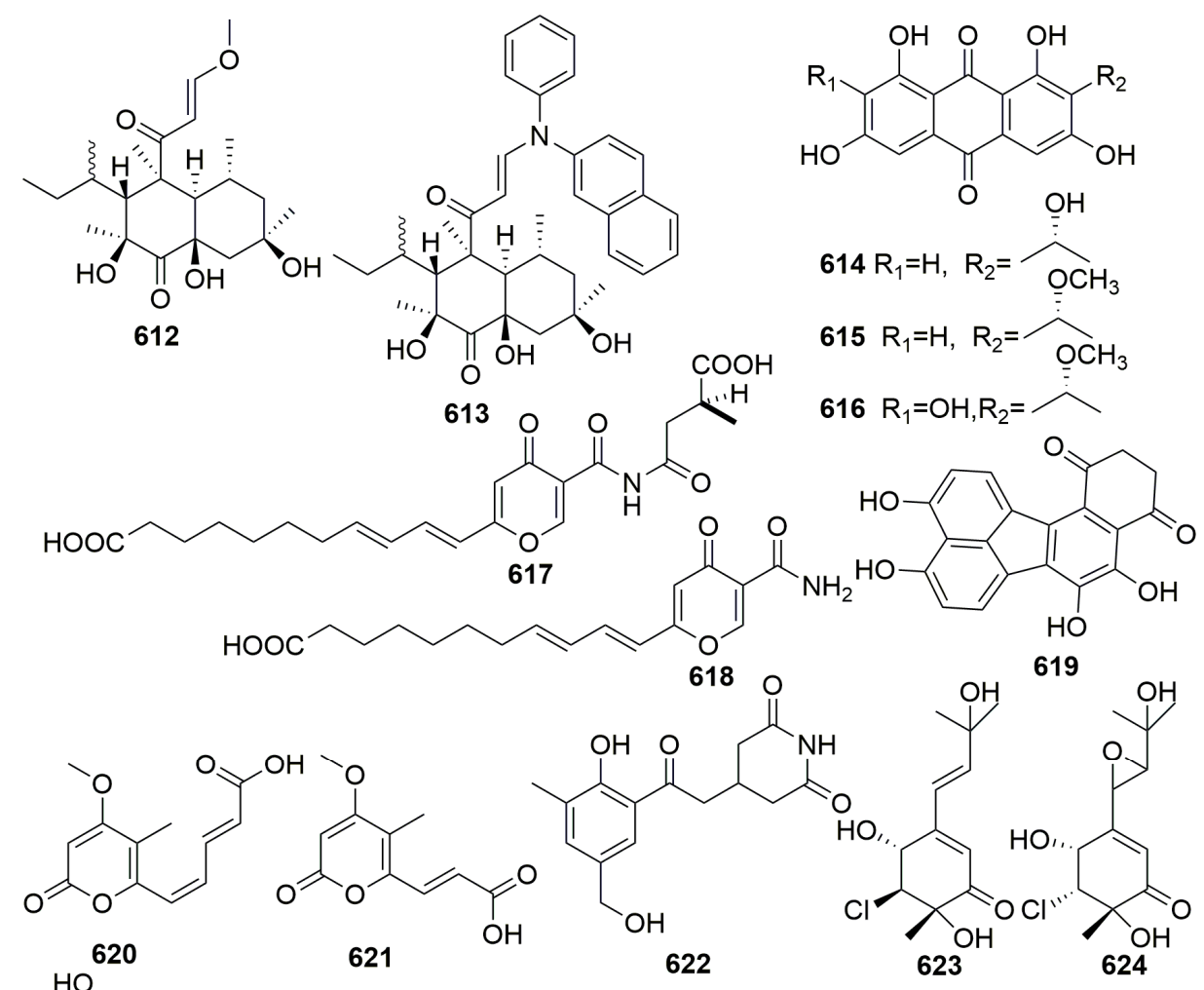

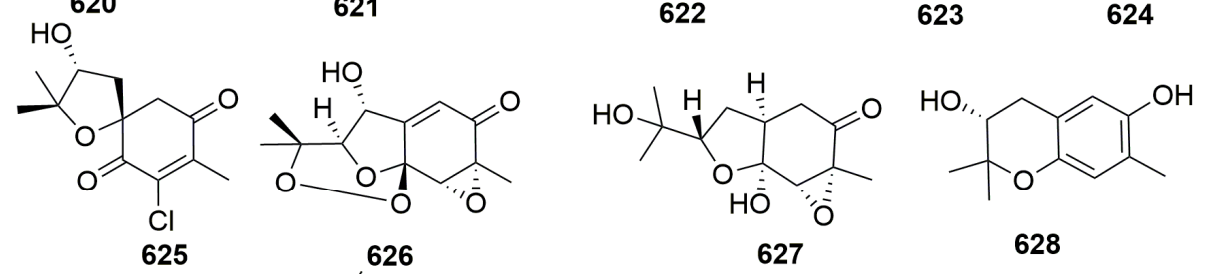

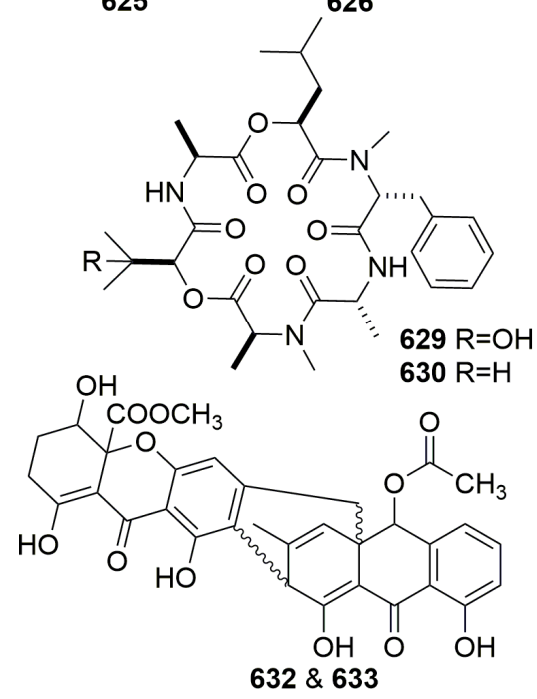<smiles>CCC(C)C(NC(=O)C1[C@H](C)CCN1C(=O)[C@H](CC(C)C)OC(=O)CCNC(=O)C(C)N(C)C(=O)C(C(C)CC)N(C)C(=O)[C@H](C)CC)C(=O)O</smiles>

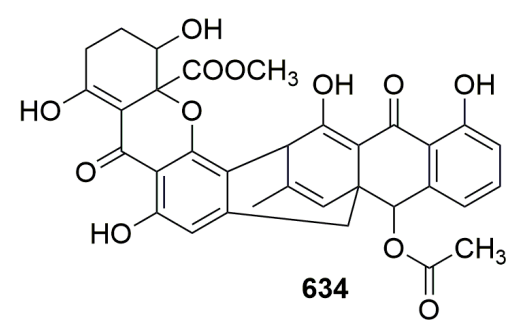

Figure 38. Chemical structures of compounds 612-634.

\subsection{Unidentified}

Two new diketopiperazines (635-636), and orcinotriol (637) (Figure 39), a new 1,3-dihydroxyphenol derivative, were isolated from the yeast Aureobasidium pullulans, which was separated from an unidentified marine sponge collected in Okinawa [213]. Four novel hexaketide compounds-iso-cladospolide B (638), seco-patulolide C (639), and the 12-membered macrolides, pandangolide 1-2 (640-641) (Figure 39)—were isolated from a marine fungal species isolated from a 
bright orange, encrusting sponge collected in Indonesia. No bioactivity was detected [214]. Chemical examination of a marine-derived fungus Aspergillus niger FT-0554 from a marine sponge (collected in Palau Islands) afforded a novel compound: nafuredin (642) (Figure 39). Compound 642 inhibited the anaerobic electron transport of Ascaris suum (pig roundworm) [215].<smiles>C=C[C@H](O)[C@@H](O)[C@H](O)[C@H](C)C[18O]</smiles>

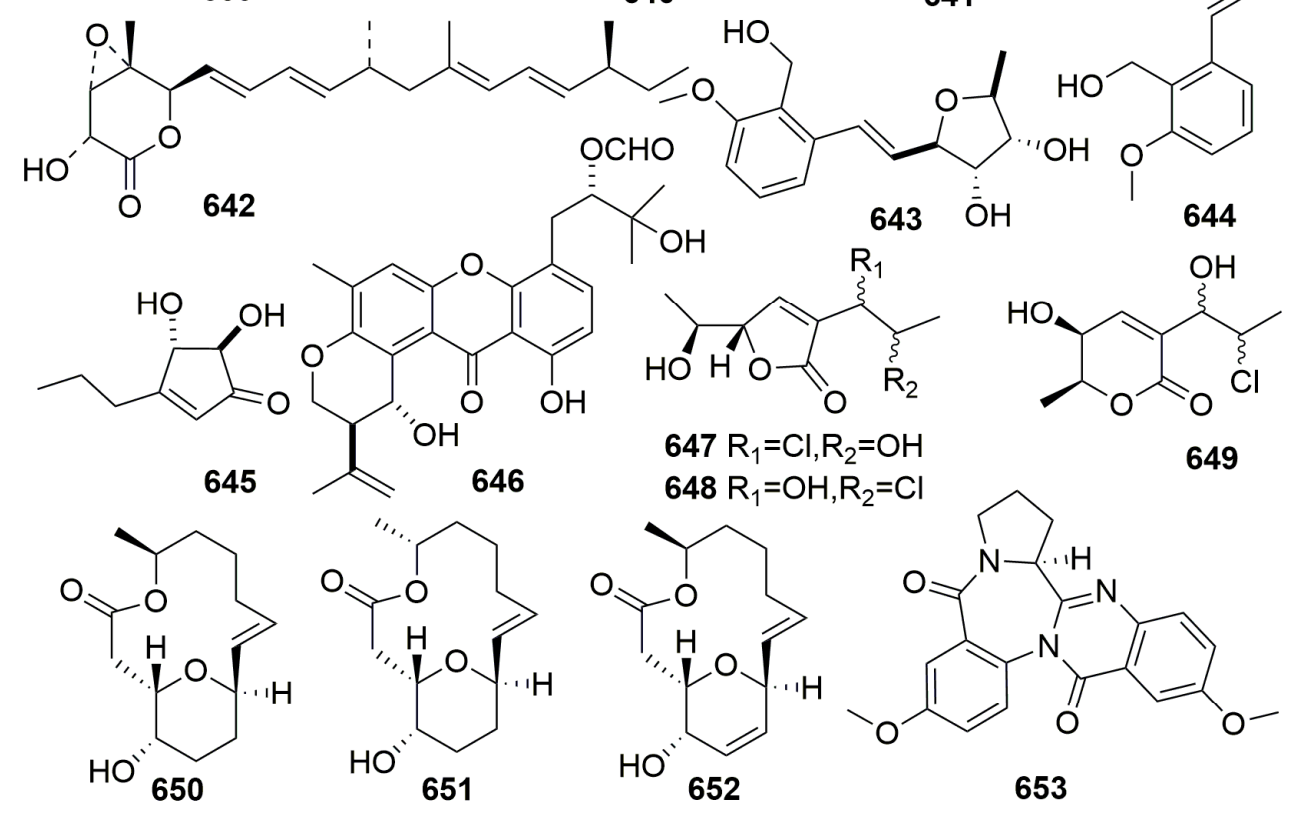

640

641<smiles>C/C=C\c1cccc(OC)c1CO</smiles>

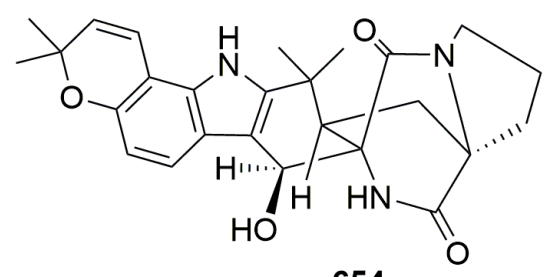

654<smiles>CCCCCCCNC(=O)CCC(=O)NCCCCCN(O)C(=O)CCC(=O)NCCCCCNC(=O)CCC(=O)NCCCCCNC(=O)O</smiles>

657

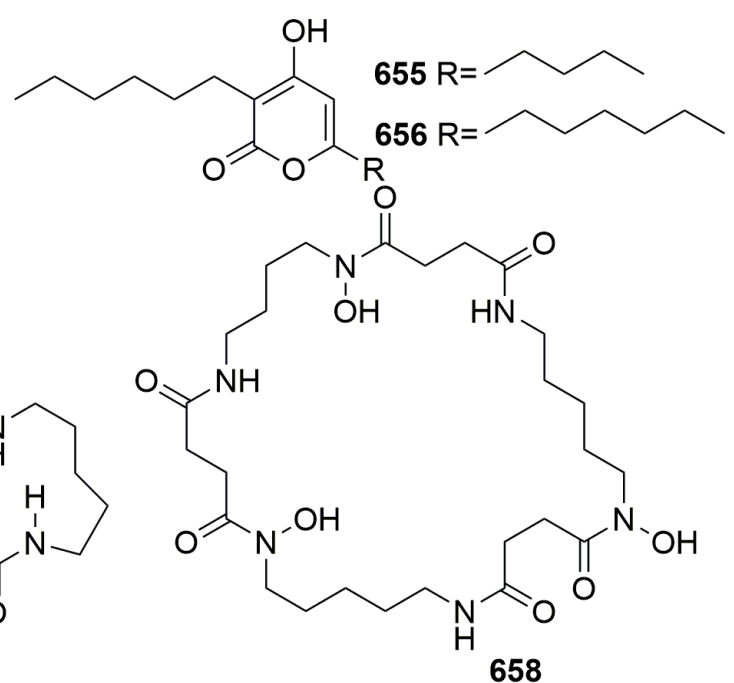

Figure 39. Structures of new molecules 635-658. 
The new compounds varitriol (643), varioxirane (644), dihydroterrein (645), and varixanthone (646) (Figure 39) were identified from the fungus Emericella variecolor, which was isolated from a sponge collected in the Caribbean waters. In the National Cancer Institute's 60-cell panel, varitriol (643) showed increased potency toward selected renal, CNS, and breast cancer cell lines. Varixanthone (646) showed antimicrobial activity against E. coli, Proteus sp., B. subtillis, and S. aureus, showing a minimal inhibitory concentration (MIC) of $12.5 \mu \mathrm{g} / \mathrm{mL}$ [216]. Three new chlorine containing compounds (647-649), three new 14-membered macrolides, named aspergillides A-C (650-652), a new compound named circumdatin J (653), and a stephacidin, 21-hydroxystephacidin A [(+)-2] (654) (Figure 39) were isolated from a marine-derived fungus Aspergillus ostianus strain TUF 01F313 isolated from a marine sponge collected at Pohnpei. Three new chlorinated compounds (647-649) showed antibacterial activity against the Ruegeria atlantica strain. Compounds 650-652 showed cytotoxic activity against mouse lymphocytic leukemia cells (L1210) with $\mathrm{LD}_{50}$ values of 2.1, 71.0, and $2.0 \mu \mathrm{g} / \mathrm{mL}$, respectively [217-220]. Chemical study of the marine-derived Pseudomonas sp. F92S91 from a marine sponge sample collected in Fiji afforded two new $\alpha$-pyrones, pseudopyronines A-B (655-656) (Figure 39). Both compounds showed moderate to poor antibacterial activities against Gram-positive bacteria [221]. The examination of an actinomycete of the genus Streptomyces isolated from an unidentified marine sponge (Korea) led to the isolation of two new cyclic peptides (657-658) (Figure 39). Both compounds exhibited weak inhibition against the enzyme sortase $B$ with $\mathrm{EC}_{50}$ values of 88.3 and $126.4 \mu \mathrm{g} / \mathrm{mL}$, respectively [222].

IB-01212, a new cytotoxic cyclodepsipeptide featuring C2 symmetry (659) (Figure 40), was isolated from cultures of the marine fungus Clonostachys sp. ESNA-A009, which was previously isolated from an unidentified marine sponge collected in Japan. Compound 659 exihibited highly cytotoxic activity to different tumor cell lines [223]. We have identified tropolactones A-D (660-663) (Figure 40), which are four new cytotoxic meroterpenoids from a marine-derived Aspergillus sp. (strain CNK-371) that was isolated from an unidentified sponge collected at Manele Bay, Hawaii. Compounds 660-661 showed moderate cytotoxicity against human colon carcinoma (HCT-116) with $\mathrm{IC}_{50}$ values of $13.2,10.9$, and $13.9 \mu \mathrm{M}$, respectively [224].

Chemical examination of a marine-derived fungus, Arthrinium sp., isolated from a marine sponge collected in the Japan Sea, yielded a new inhibitor of p53-HDM2 interaction (664) (Figure 40). Compound 664 inhibited the p53-HDM2 binding with an $\mathrm{IC}_{50}$ value of $50 \mu \mathrm{g} / \mathrm{mL}$ [225]. A new macrocyclic trichothecene, named roridin R (665) (Figure 40), was from the fungus Myrothecium sp. TUF 02F6, which was isolated from an unidentified marine sponge collected in Manado, Indonesia. Compound 665 showed significant cytotoxicity against the murine leukemia cell line L1210 with an $\mathrm{IC}_{50}$ value of $0.45 \mu \mathrm{M}$ [226]. Three new polyketide-originated compounds (666-668) (Figure 40) were isolated from a marine fungus Mycelia sterilia derived from a sponge [227]. One new siderophore (669) (Figure 40) was isolated from a bacterium isolated from unidentified marine sponges collected in Indonesia. The MIC value of the compound $\mathbf{6 6 9}$ by chrome azurol S (CAS) liquid assay is $156 \mu \mathrm{g} / \mathrm{mL}$ [228]. Chemical investigation of the marine-derived fungus Fusarium sp. 05ABR26 led to the isolation of a new $\beta$-resorcylic macrolide, $5^{\prime}$-hydroxyzearalenol (670) (Figure 40). The strain 05ABR26 was isolated from a sponge collected in Miura Peninsula of Japan. Compound $\mathbf{6 7 0}$ showed no obvious activity against Pyricularia oryzae [229]. Three new aminolipopeptides that were designated trichoderins A (671), A1 (672), and B (673) (Figure 40) were from fungus Trichoderma sp. 05FI48, which was isolated from the unidentified marine sponge. Trichoderins showed potent anti-mycobacterial activity against Mycobacterium smegmatis, Mycobacterium bovis BCG, and Mycobacterium tuberculosis $\mathrm{H} 37 \mathrm{Rv}$ with MIC values ranging from 0.02 to $2.0 \mu \mathrm{g} / \mathrm{mL}$ [230]. Chemical investigation of the marine sponge-associated Actinomadura sp. SpB081030SC-15, which was obtained from an unidentified marine sponge (Japan), led to the isolation of a new diterpene compound designated JBIR-65 (674) (Figure 40). The bioassays of compound 674 were disappointing [231]. An investigation of the marine sponge-derived Streptomyces sp. strain RM72 from an unidentified marine sponge (Japan) yielded three new trichostatin analogues, JBIR 109-111 (675-677) (Figure 40). The IC 50 values against HDAC1 of compounds $675-677$ were 48,74 , and $57 \mu \mathrm{M}$, respectively [232]. Three new depsipeptides termed 
JBIR 113-115 (678-680) (Figure 40) were isolated from a culture of Penicillium sp. fS36, which were isolated from an unidentified marine sponge collected near Takarajima Island, Japan. Compounds 678-680 did not show cytotoxicity to human cervical carcinoma HeLa cells lines $\left(\mathrm{IC}_{50}>100 \mu \mathrm{M}\right)$ or antimicrobial activity against Micrococcus luteus or Escherichia coli [233].

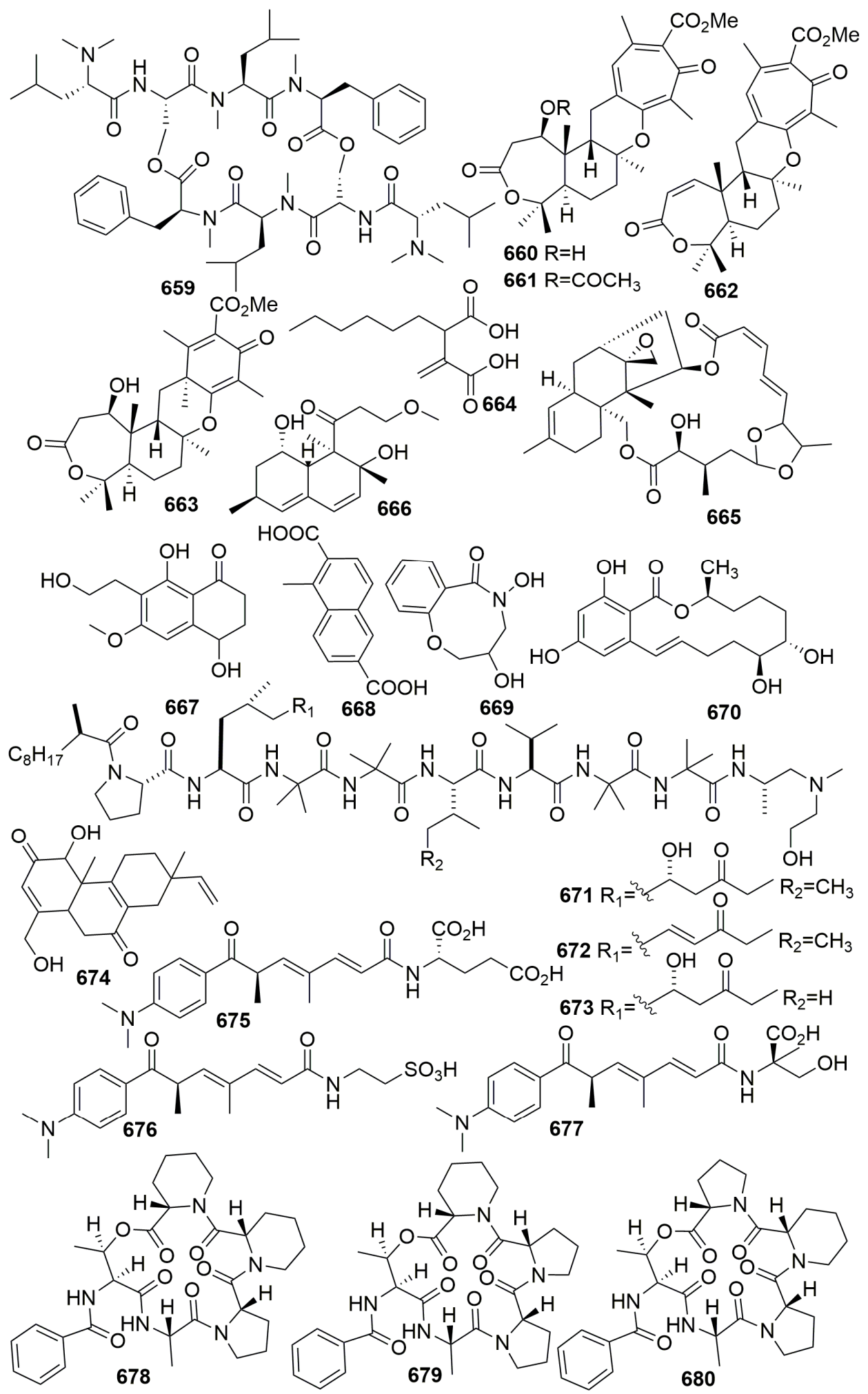

Figure 40. Structures of new compounds 659-680. 
Chemical investigation of a marine sponge-derived fungus, Aspergillus unguis CRI282-03, derived from an unidentified marine sponge CRI282 (collected in Thailand), afforded three new depsidones (681-683), a new diaryl ether (684), and a new natural pyrone (685) (Figure 41). Compounds 681-682 showed radical scavenging activity, and compound 683 showed the most potent aromatase inhibitory activity with the $\mathrm{IC}_{50}$ value of $0.74 \mu \mathrm{M}$. Compound 684 exhibited moderate cytotoxic activity against MOLT-3 cancer cell lines with an $\mathrm{IC}_{50}$ value of $8.8 \mu \mathrm{M}$ [234]. 1-Hydroxy-10-methoxy-dibenz [b, e] oxepin-6,11-dione (686) (Figure 41) was purified from the fungus strain of Beauveria bassiana TPU942, which was associated with a marine sponge collected in Okinawa, Japan. Compound 686 did not show any apparent activity in the bioassays [235]. Chemical study of the sponge-derived fungus, Gymnascella dankaliensis, afforded a new polyketide tyrosine derivative, dankastatin C (687) (Figure 41). Compound 687 showed potent cell growth inhibitory activity against the murine P388 cell line with an $\mathrm{ED}_{50}$ value of $57 \mathrm{ng} / \mathrm{mL}$ [236]. Fractionation of the marine-derived fungus Metarhizium anisopliae mxh-99 from an unidentified sponge (Guangxi Province, China) yielded two new naphtho-c-pyrones glycosides, indigotides G-H (688-689) (Figure 41) [237]. Chemical examination of a marine-derived Kocuria palustris strain F-276345, which was isolated from a sponge sample (collected in Florida Keys, United States of America), yielded a new thiazolyl peptide, kocurin (690) (Figure 41). Compound 690 displayed activity against methicillin-resistant Staphylococcus aureus (MRSA), with an MIC value of $0.25 \mu \mathrm{g} / \mathrm{mL}$ [238]. One new compound (691) (Figure 41) was isolated from the marine fungus Paecilomyces sp. cultured from the marine sponge (collected along Tinggi Island, Malaysia). Compound 691 inhibited MRSA, with inhibition zones of $8( \pm 0.07) \mathrm{mm}$ [239].<smiles>C/C=C(/C)c1c2c(c(C)c(O)c1C(=O)O)OC(=O)c1c(C)cc(O)cc1O2</smiles>

681

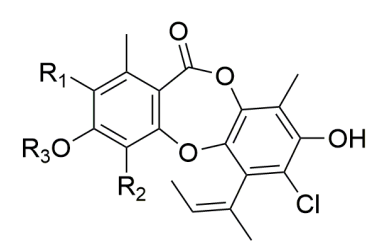

$682 \mathrm{R}_{1}=\mathrm{H}, \mathrm{R}_{2}=\mathrm{Cl}, \mathrm{R}_{3}=\mathrm{Me}$ $683 \mathrm{R}_{1}=\mathrm{Cl}, \mathrm{R}_{2}=\mathrm{H}, \mathrm{R}_{3}=\mathrm{H}$ HO<smiles>COc1cccc2c(=O)oc3cccc(O)c3c(=O)c12</smiles><smiles>C/C=C(\C)c1cc(O)c(C)c(=O)o1</smiles><smiles>O[18OH]</smiles><smiles>COC1C2COC(CO2)C(O)C1O</smiles>
O 686<smiles>C/C=C/CCCCCCCC</smiles>

687<smiles>[R16]c1cc2c(c(O)c1C(=O)C(C)CC)O[C@@H](C)[C@H](C)C2=O</smiles>

Figure 41. Structures of new marine natural products 681-691 derived from sponge (unidentified)-associated microbes. 
Chemical examination of the sponge-derived fungus Penicillium sp. MWZ14-4, which was isolated from an unidentified sponge (collected from the South China Sea), yielded 10 new fungal metabolites, including three hydroisocoumarins, penicimarins A-C (692-694), three isocoumarins, penicimarins D-F (695-697), and four benzofurans, penicifurans A-D (698-701) (Figure 42). Penicifuran A (698) showed moderate inhibitory activity against Staphylococcus albus with an MIC value of $3.13 \mu \mathrm{M}$ and weak activity against B. cereus [240]. Two new tetracenedione derivatives, nocatriones A-B (702-703) (Figure 42), were isolated from the actinomycete Nocardiopsis sp. KMF-002, which was previously isolated from an unidentified sponge (Korea). Compounds 702-703 may show antiphotoaging activity in UVB-irradiated models [241].<smiles></smiles><smiles>[R]c1oc(=O)c2c(O)cc(O)cc2c1[R]</smiles>

$696 \mathrm{R}_{1}=\mathrm{CH}_{2} \mathrm{OCOMe}, \mathrm{R}_{2}=\mathrm{CH}_{3}$

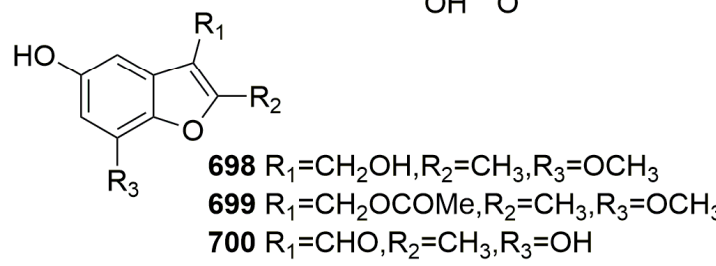
$697 \mathrm{R}_{1}=\mathrm{CH}_{2} \mathrm{OH}, \mathrm{R}_{2}=\mathrm{CH}_{2} \mathrm{OH}$

$700 \mathrm{R}_{1}=\mathrm{CHO}, \mathrm{R}_{2}=\mathrm{CH}_{3}, \mathrm{R}_{3}=\mathrm{OH}$<smiles>C/C=C\C=C/[C@H]1Cc2cc(O[14CH3])cc(OC3OC(C)C(O)C3(O)O)c2O1</smiles>
706<smiles>CC=CCC=C(C)C</smiles>
H

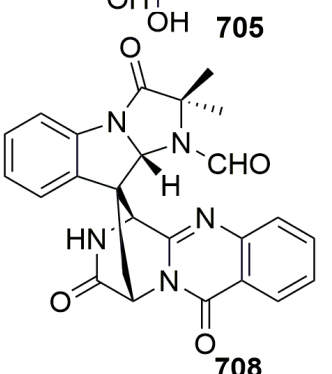

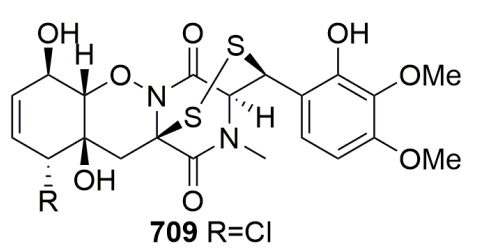

707 Oे

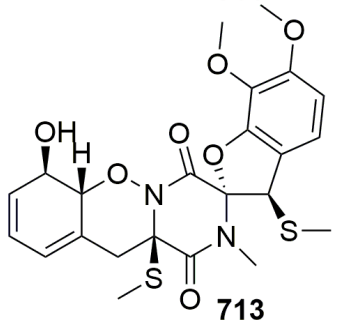

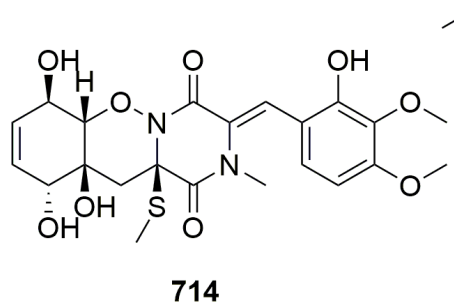

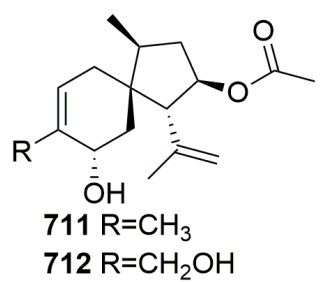<smiles>COC(=O)C1(O)OC(=O)C(Cc2ccc(O)c(CC=C(C)C)c2)=C1c1ccc(O)cc1</smiles>

Figure 42. Chemical structures of new marine natural products 692-715 derived from sponge-derived microbes. 
Xylarianaphthol-1, a novel dinaphthofuran derivative (704) (Figure 42), was isolated from fungus of order Xylariales strain 05FI52, which was isolated from the unidentified marine sponge collected in Indonesia. Compound 704 activated the p21 promoter, which was stably transfected in MG63 cells dose-dependently [242]. Three new secondary metabolites, amycofuran (705), amycocyclopiazonic acid (706), and amycolactam (707) (Figure 42) were isolated from the sponge-associated rare actinomycete Amycolatopsis sp. isolated from a sponge sample gathered from Micronesia. Amycolactam (707) displayed significant to moderate cytotoxicity against the gastric cancer cell line SNU638, the colon cancer cell line HCT116, A546, K562, and SK-HEP1 with $\mathrm{IC}_{50}$ values of $0.8,2.0,13.7,9.6$, and $8.3 \mu \mathrm{M}$, respectively [243]. Chemical study of the marine-derived fungus Penicillium adametzioides AS-53 from an unidentified marine sponge (collected from Hainan, China) afforded a new spiroquinazoline derivative, N-Formyllapatin A (708), two new bisthiodiketopiperazine derivatives, adametizines A-B (709-710), two new acorane sesquiterpenes, adametacorenols A-B (711-712), a new dithiodiketopiperazine derivative, peniciadametizine A (713), and a highly oxygenated new analogue, peniciadametizine B (714) (Figure 42). Compound 709 exhibited lethality against brine shrimp (Artemia salina) with an $\mathrm{LD}_{50}$ value of $4.8 \mu \mathrm{M}$ and moderate antimicrobial potency against several microbes with MIC values ranging from 8 to $32 \mu \mathrm{g} / \mathrm{mL}$, respectively, whereas compound 710 only showed weak activity against $S$. aureus (MIC, $64 \mu \mathrm{g} / \mathrm{mL}$ ). Compound 712 showed significant selective activity against the NCI-H446 cell line $\left(\mathrm{IC}_{50}=5.0 \mu \mathrm{M}\right)$. Compounds 713 and 714 showed inhibitory activity against the pathogenic fungus Alternaria brassicae with MIC values of 4.0 and $32.0 \mu \mathrm{g} / \mathrm{mL}$, respectively [244-246]. Chemical examination of a marine fungus Aspergillus terreus MXH-23, isolated from an unidentified sponge (collected from Guangdong Province, China), yielded a new butyrolactone derivative, namely butyrolactone VIII (715) (Figure 42). Derivative 715 did not show antiviral activity [247].

A new (716) sesquiterpenoid and two new (717-718) (Figure 43) xanthone derivatives were isolated from the fungus Stachybotry sp. HH1 ZDDS1F1-2, which was isolated from an unidentified sponge (Xisha Island, China). Compounds 717-718 exhibited significant inhibitory activity against cyclooxygenase (COX-2) with $\mathrm{IC}_{50}$ values of 10.6 and $8.9 \mu \mathrm{M}$, respectively. Besides, compound 718 displayed activities against intestinal virus EV71 with $\mathrm{IC}_{50}$ values of $30.1 \mu \mathrm{M}$ [248]. The examination of the sponge-associated Micromonospora sp. NPS2077 isolated from an unidentified marine sponge (collected at Uranouchi Bay, Japan) led to the isolation of a novel $\beta$-hydroxyl- $\delta$-lactone compound, neomacquarimicin (719) (Figure 43), which exhibited no activities against the Bacillus subtilis and Escherichia coli [249]. One new bisabolane-type sesquiterpenoid, aspergillusene C (720) (Figure 43), was isolated from sponge-associated fungi, the fungal strain ZSDS1-F6, which was identified as Aspergillus sydowii; it was isolated from an unidentified marine sponge (Xisha Islands, China). No bioactivities were detected [250]. One new naphthalene derivative (721) (Figure 43) was from Fungus Arthrinium sp. ZSDS1-F3, which was isolated from an unidentified sponge (Xisha Islands, China) [251]. Chemical study of the marine-derived fungus Verrucosispora sp. FIM06054 from a marine sponge sample (the East China Sea) afforded a new compound, FW054-1 (722) (Figure 43). Compound 722 showed antiproliferative activity against human tumour cells CNE-2 with $\mathrm{IC}_{50}$ values of $6.88 \mu \mathrm{M}$ [252]. 


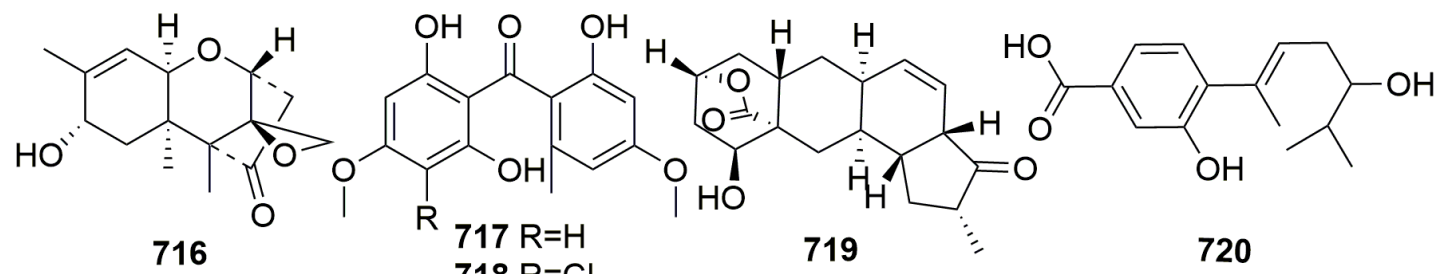

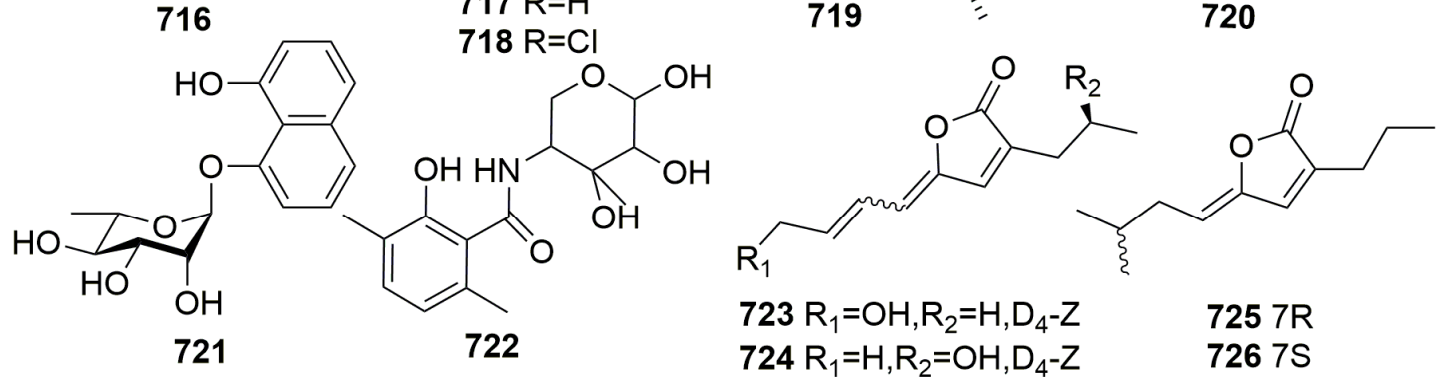

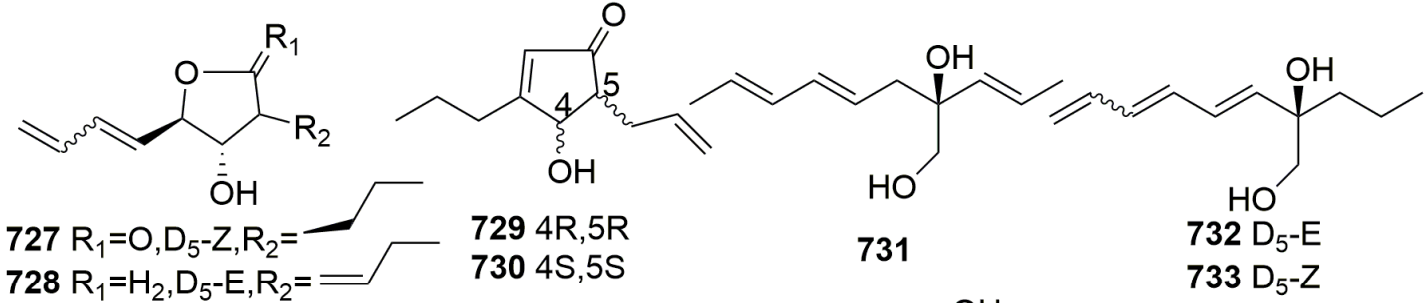

$728 \mathrm{R}_{1}=\mathrm{H}_{2}, \mathrm{D}_{5}-\mathrm{E}, \mathrm{R}_{2}=$<smiles></smiles>

$736 \mathrm{R}=(\mathrm{R})-\mathrm{OH}, 5 \mathrm{R}$ $737 \mathrm{R}=(\mathrm{S})-\mathrm{Cl}, 5 \mathrm{~S}$<smiles>C/C=C/C1=C(CO)[C@@H](O)[C@H](O)[C@H]2OC(=O)O[C@H]12</smiles><smiles>CC(=O)N[C@H](C(=O)O[C@H]1CCC(C)(C)[C@@H]2C[C@H](O)C3=C(COC3=O)[C@]12C)C(C)C</smiles>
744

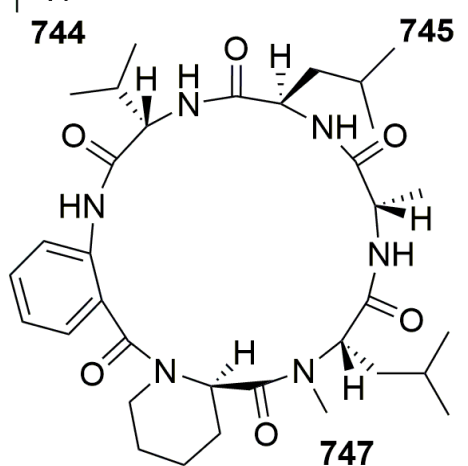

740
735<smiles>CCC[C@H]1C[C@H]2OC(=O)c3c(cc(O)c(OC)c3O)[C@H]2O1</smiles><smiles>CC(=O)N[C@H](C(=O)O[C@H]1C[C@@H]2[C@@H](C3=C1C(=O)OC3)[C@@H](O)CCC2(C)C)C(C)C</smiles><smiles>O=C(O)c1ccccc1I</smiles><smiles>CCCCCC(=O)C(NC(C)=O)C(C)C1CCCCC1</smiles><smiles>[R]C1C[C@H]2C(C)(C)CC[C@@H](OC(C)=O)[C@@]2(C)C2=C1C(=O)OC2</smiles>

$742 \mathrm{R}=\mathrm{Cl}$

$743 \mathrm{R}=\mathrm{OH}$

\section{1}

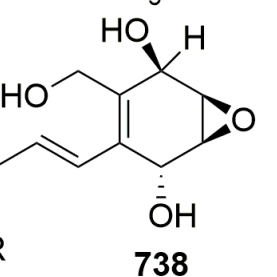

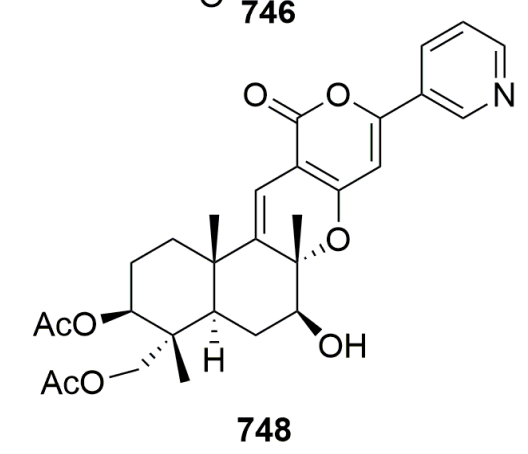

Figure 43. Structures of new compounds 716-748. 
Fractionation of the marine fungus Aspergillus sp. OUCMDZ-1583 from an unidentified sponge XD10410 (collected from the Xisha Islands, China) yielded 18 new compounds named aspergones A-Q (723-739) and 6-O-demethylmonocerin (740) (Figure 43). Compounds 723, 724, 727, 732, 733, and 736-740 showed a-glucosidase inhibition with $\mathrm{IC}_{50}$ values of 2.36, 1.65, 1.30, 2.37, 2.70, 1.36, $1.54,2.21,2.26$, and $0.027 \mathrm{mM}$, respectively. Besides, compound 740 showed anti-H1N1 activity against the influenza $\mathrm{A}$ virus with $\mathrm{IC}_{50}$ values of 172.4 and $175.5 \mu \mathrm{M}$, respectively (with ribavirin as the positive control; $\mathrm{IC}_{50}, 137.3 \mu \mathrm{M}$ ) [253]. Chemical examination of a marine-derived fungus Penicillium chrysogenum SYP-F-2720 from an unidentified sponge (collected off the North Sea coast, China) afforded a novel benzoic acid (741) (Figure 43). When administered at $100 \mathrm{mg} / \mathrm{kg}$, compound 741 displayed more significant anti-inflammatory and analgesic activities than aspirin; however, it did not have an ulcerogenic effect [254]. Study of the sponge-derived fungus Talaromyces minioluteus PILE 14-5 derived from an unidentified marine sponge (collected in Thailand) afforded four new sesquiterpene lactones (742-745) (Figure 43). Compounds 742 and 745 exhibited weak cytotoxic activity with $\mathrm{IC}_{50}$ values ranging from 50.6 to $193.3 \mu \mathrm{M}$ [255]. The investigation of an unidentified marine sponge derived fungus, Aspergillus similanensis KUFA 0013, yielded a new isocoumarin derivative, similanpyrone C (746), a new cyclohexapeptide, similanamide (747), and a new pyripyropene derivative, named pyripyropene $\mathrm{T}$ (748) (Figure 43). Only compound 747 exhibited weak activity against the MCF-7 (breast adenocarcinoma), NCI-H460 (non-small cell lung cancer), and A373 (melanoma) cell lines, and neither of them showed antibacterial activity [256].

The fungus Corynespora cassiicola XS-200900I7, isolated from an unidentified sponge XS-2009001 (collected from the Xisha Islands, China), yielded 12 new chromone derivatives, corynechromones A-L (749-760), two new naphthalenones, corynenones A-B (761-762), and one new depsidone, corynesidone E (763) (Figure 44). The bioassay was disappointing [257,258]. S-Bridged pyranonaphthoquinone dimers, naquihexcins A-B (764-765) (Figure 44), were metabolized by a sponge-derived Streptomyces sp. HDN-10-293 isolated from the marine sponge. Compound 764 could inhibit the proliferation of the adriamycin-resistant human breast cancer cell line MCF-7 ADM with an IC $_{50}$ value of $16.1 \mu \mathrm{M}$ (adriamycin as positive control, $\mathrm{IC}_{50}>20.0 \mu \mathrm{M}$ ) [259]. Two new structurally unique compounds bearing a nitrogen and sulfur-containing tricyclic ring system, ulbactin F-G (766-767) (Figure 44), were metabolized by a sponge-derived Brevibacillus sp. strain TP-B0800 associated with an unidentified sponge collected in Iwate, Japan. Both compounds 766 and 767 inhibit the migration of epidermoid carcinoma A431 cells at non-cytotoxic concentrations with $\mathrm{IC}_{50}$ values of 6.4 and $6.1 \mu \mathrm{M}$, respectively [260]. Chemical investigation of a marine-derived fungus Aspergillus aureolatus HDN14-107 from an unidentified sponge (collected at Xisha Islands, China) led to the isolation of three new meroterpenoids, named austalides S-U (768-770) (Figure 44). Compound 770 exhibited anti-H1N1 activities against influenza virus $A$ with $\mathrm{IC}_{50}$ values of $90 \mu \mathrm{M}$ [261].

Chemical analysis of the recombinant Streptomyces albus PVA94-07 strain derived from an unidentified sponge afforded two new deferoxamine analogues, compounds 771-772 (Figure 45). Compounds 771-772 exhibited no cytotoxic activity on these tested cell lines [262]. Chemical analysis of the strain Aspergillus sp. SCSIO XWS03F03 derived from a sponge (collected in Guangdong Province, China) afforded two new polyketides, aspergchromones A-B (773-774) (Figure 45). Compounds 773-774 showed no antimicrobial activity against Staphyloccocus aureus and Mycobacterium tuberculosis [263]. 
<smiles>[R6]C(=O)Cc1cc(O)c([R])c2c1C(=O)CC([R])([R])O2</smiles>

$749 \mathrm{R}_{1}=\overbrace{}^{5} \mathrm{R}_{2}=\mathrm{R}_{3}=\mathrm{H} \quad \mathrm{R}_{4}=\xi^{\mathrm{S}}$ $750 \mathrm{R}_{1}=\mathrm{R}_{3}=\mathrm{H} \quad \mathrm{R}_{2}=3^{5} \mathrm{R}_{4}=5_{5}^{5}$ $751 \mathrm{R}_{1}=s^{5} \mathrm{R}_{2}=\mathrm{R}_{3}=\mathrm{H}_{\mathrm{O}} \mathrm{R}_{4}=3^{5}$ $752 \mathrm{R}_{1}=\mathrm{R}_{3}=\mathrm{H}_{\mathrm{OH}} \mathrm{R}_{2}=$ s $\mathrm{R}_{4}=$ s $753 \mathrm{R}_{1}=\mathrm{R}_{2}=\mathrm{R}_{3}=\mathrm{R}_{4}=\mathrm{H}$ $754 R_{1}=R_{3}=R_{4}=\mathrm{H}_{2}=$ s $755 \mathrm{R}_{1}=\underbrace{5} \mathrm{R}_{2}=\mathrm{R}_{4}=\mathrm{H}_{\mathrm{OH}} \mathrm{R}_{3}=\mathrm{OCH}_{3}$ $756 \mathrm{R}_{1}=\mathrm{R}_{4}=\mathrm{H} \quad \mathrm{R}_{2}=\mathrm{s}^{5} \mathrm{R}_{3}=\mathrm{OCH}_{3}$ $757 R_{1}=R_{3}=R_{4}=H R_{2}=$ s.<smiles>O=C1C2CC(S2)C2N1C1CSC(C3CSC(c4ccccc4O)=N3)N12</smiles>

766

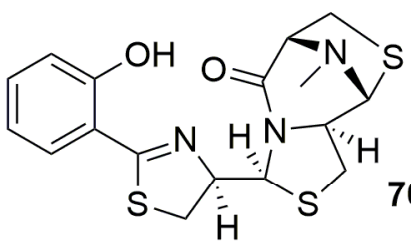<smiles>[R]OC(=O)Cc1cc(O)cc2oc([R])cc(=O)c12</smiles>

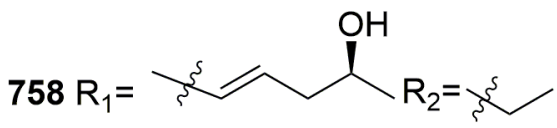

$759 \mathrm{R}_{1}=\mathrm{CH}_{3}$ $760 \mathrm{R}_{1}=\mathrm{CH}_{3}$ $R_{2}=x^{s}$

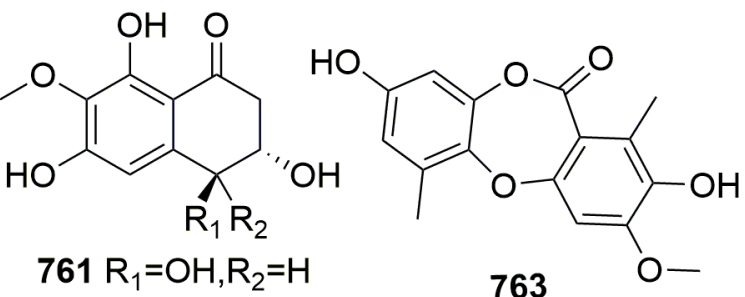

$762 \mathrm{R}_{1}=\mathrm{H}, \mathrm{R}_{2}=\mathrm{OH}$<smiles>[R]C[C@H]1C[C@@]2(S)[C@@H](C)O[C@H](C)[C@@]2(O)C(=O)c2cccc(O)c2C1=O</smiles><smiles>Cc1c2c(c(O)c3c1O[C@H]1CC[C@@H]4C(CC[C@@H](O)C4(C)C)[C@@H]3C1)OC(=O)C2</smiles>

768

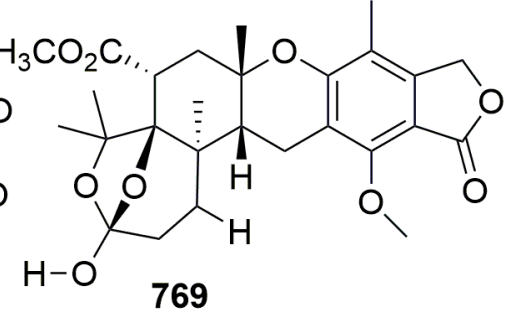

769<smiles>[R2]C[C@H]1C[C@@]2(O)C(=C)c3cccc(O)c3C(=O)[C@@]2(O)[C@@H](C)O1</smiles>

$765 \mathrm{R}_{1}=\mathrm{CH}_{2} \mathrm{OH}, \mathrm{R}_{2}=\mathrm{CH}_{2} \mathrm{OH}$

Figure 44. Structures of new molecules 749-770.<smiles>COc1c2c(c(C)c3c1[C@H]1[C@@H]4CCC(=O)OC(C)(C)C4(O)[C@H](O)C[C@@]1(C)O3)COC2=O</smiles>

770 


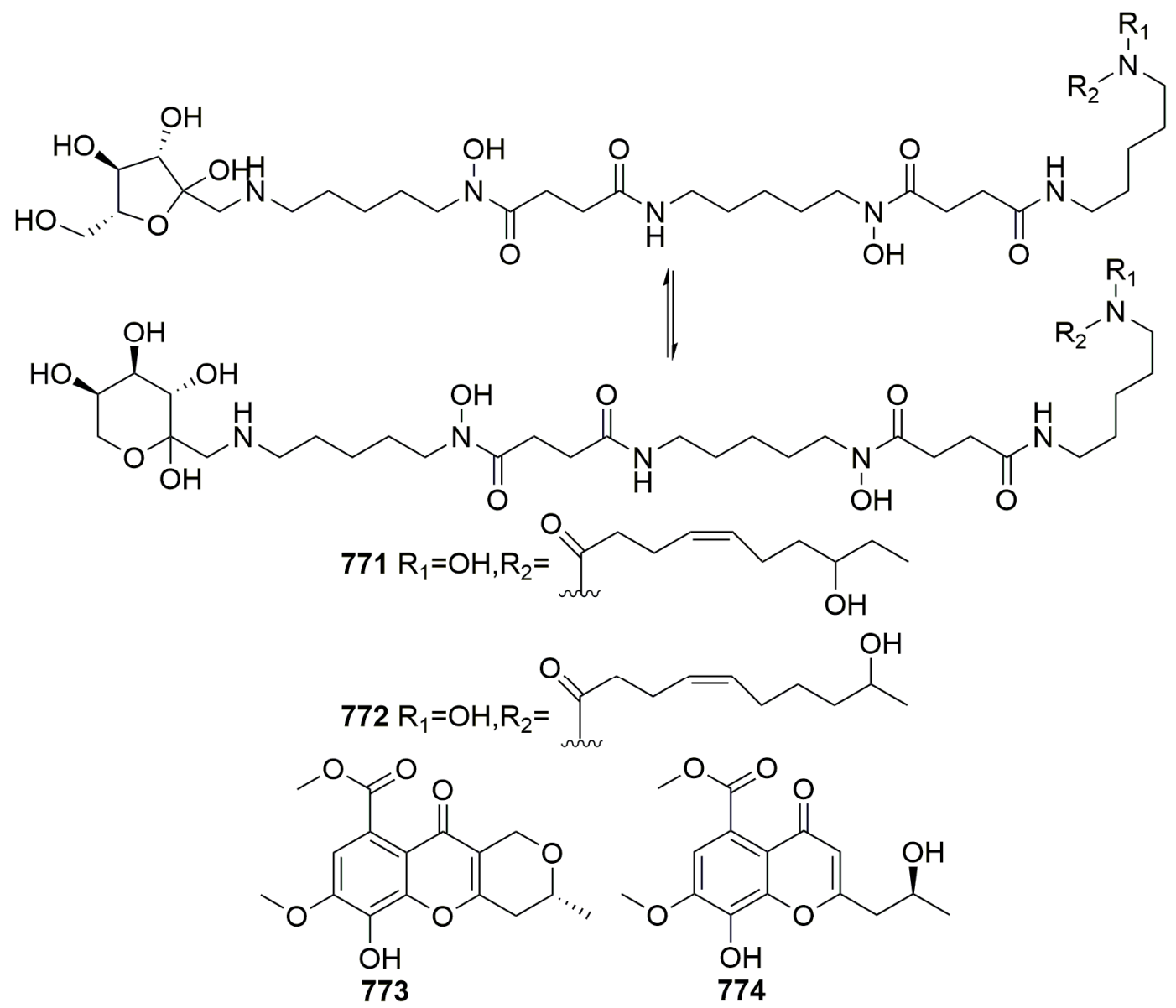

Figure 45. Structures of new marine natural products 771-774 derived from microbes, which were associated with the unidentified sponge.

\section{Statistical Analysis of Sponge-Derived Microorganisms}

\subsection{Geographical Distribution of Sponge-Derived Microorganisms}

As what we described above, temperate and tropical sea areas have become the main regions with sponge-derived microorganisms related to natural product chemistry. Figure 46 presented a visible-direct sketch map for geographical distribution of sponge-derived microorganisms. The studied species of microbial communities associated with sponges has so far mostly been focused on the Pacific coasts, including the South China Sea, Sea of Japan, Gulf of Thailand, Korean Peninsula, Indonesian Islands, Eastern China Sea, and the Great Barrier Reef, Australia. Of these, the South China Sea and the Sea of Japan are the most active hotspots, and the followings are the Mediterranean Sea, the West Atlantic Ocean, including the Gulf of Mexico and the Caribbean Island, the North Sea, the Black Sea, and then the Red Sea. 


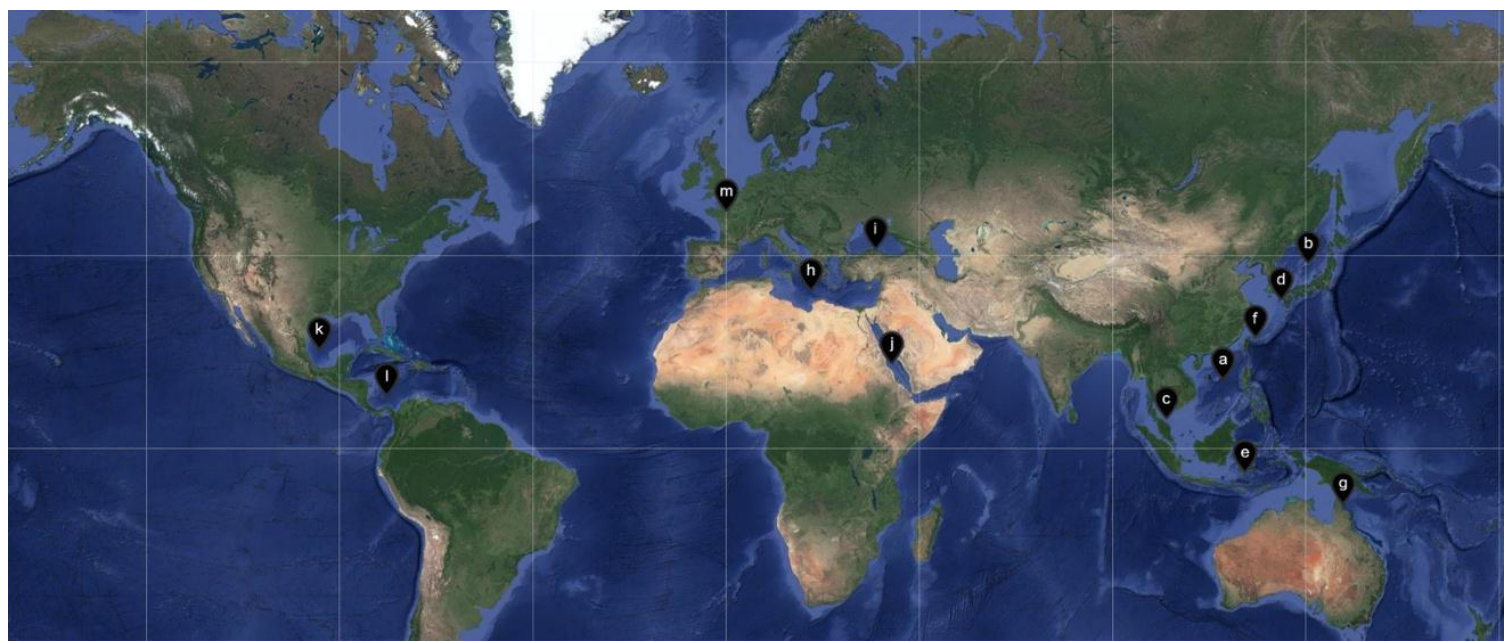

Figure 46. Geographical hotspot distribution for research on sponge-derived microorganisms. The red circles represent the hotspots of research: (a) South China Sea; (b) Sea of Japan; (c) Gulf of Thailand; (d) Korean Peninsula; (e) Indonesian Islands; (f) Eastern China Sea; (g) Great Barrier Reef, Australia; (h) the Mediterranean Sea; (i) the Black Sea; (j) the Red Sea; (k) the Gulf of Mexico; (1) the Caribbean Island; (m) the North Sea.

\subsection{Biodiversity of Microbial-Associated Sponge Hosts}

The statistical data shows that all the sponge hosts associated with microbes were distributed in the classes of Calcarea, Demospongiae, and unidentified sponges. The class Demospongiae sponges accounts for absolute majority at $77 \%$, the class Calcarea and others sponges account for $1 \%$ and $22 \%$, respectively. In the class Demospongiae, the order Haplosclerida provides the most sponge species accounting for $26.75 \%$ of the totality, followed by the orders Suberitida, Axinellida, Dictyoceratida, Tetractinellida, and Poecilosclerida etc. (see Figure 47).

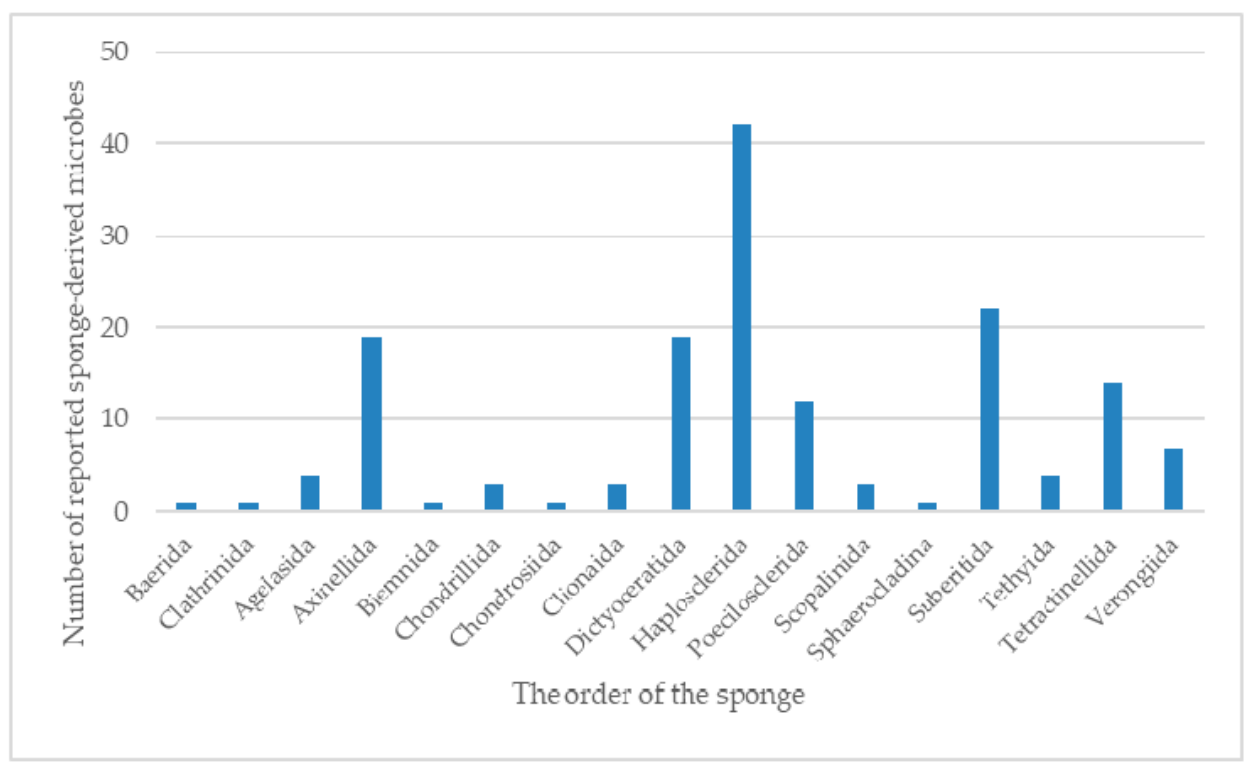

Figure 47. Distribution of research on sponges from which the microbes are derived.

\subsection{Biodiversity of Sponge-Derived Microorganisms}

In the process of long-term co-evolution, there may be some sponge-derived microbes with wonderful symbiotic relationships in the sponge ecosystem, which cover fungi, bacteria, actinomycetes, 
cyanobacteria, and archaea. With no doubt, fungi, bacteria and actinomycetes are the main producers of prolific natural products with therapeutic effects among the sponge-derived microbes (see Figure 48), and the microbes appear to be distributed randomly in the investigated host sponges. Fungi are an important component of sponge-derived microbes-up to 73\%—and more than 55 genera strains have been cultured. The fungi studied mainly belonged to the genera Aspergillus and Penicillium, followed by Trichoderma, Acremonium, Arthrinium, and Talaromyces. The genera Aspergillus and Penicillium obtained from many different sponge species take a percentage of $25 \%$ of the total microbes reported, the majority of which displayed wonderful chemistry diversity. Actinomycetes and bacteria account for $16 \%$ and $11 \%$ of sponge-derived microbes, respectively, which offered many novel and unique compounds. The actinomycetes studied were mainly derived from the genera Streptomyces, and the bacteria were mainly derived from the genera Pseudomonas, Pseudoalteromonas, and Bacillus (see Figure 48).

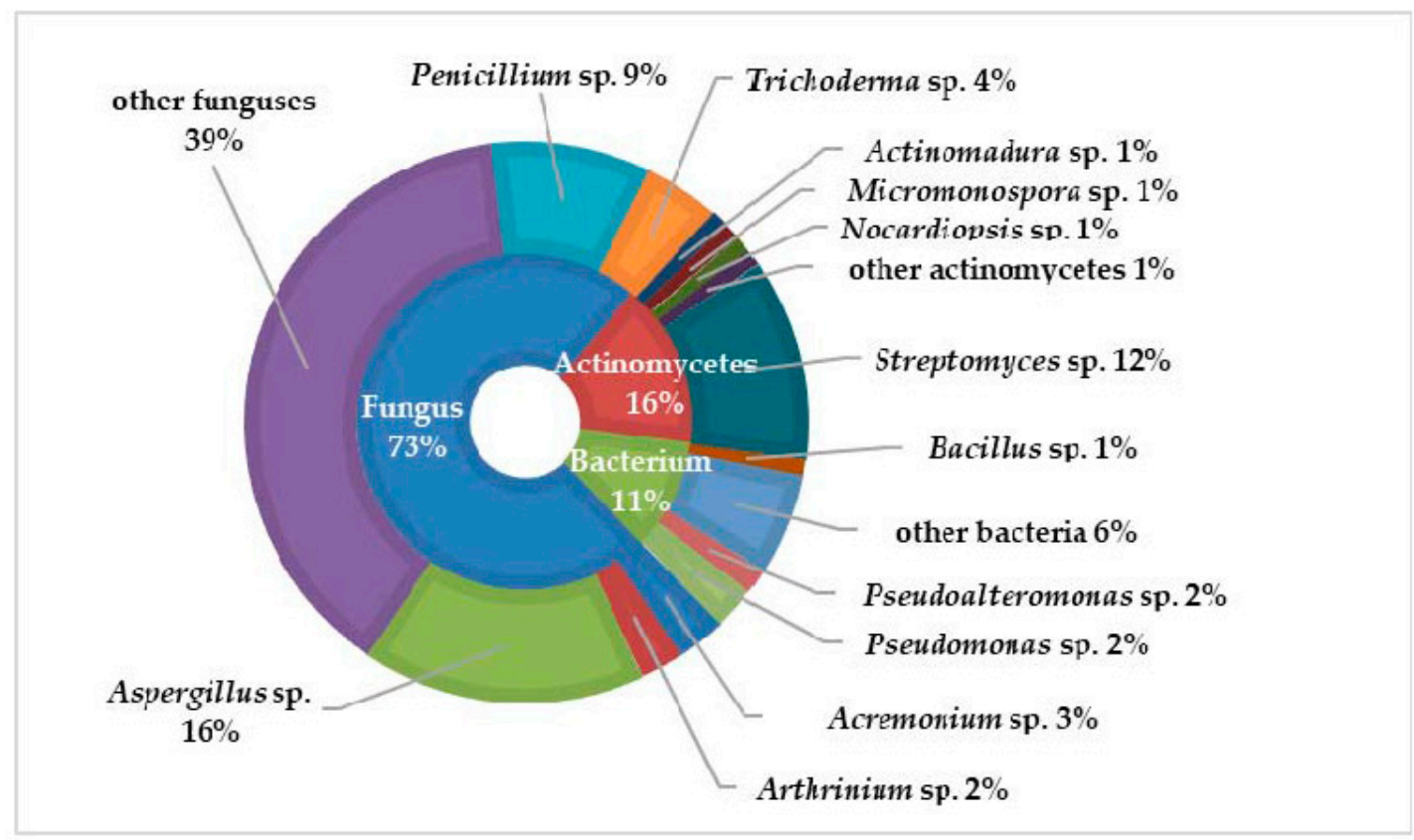

Figure 48. Percentage distribution of studies on sponge-derived microorganisms.

\subsection{Chemical Diversity and Bioactive Diversity of Sponge-Derived Microorganisms}

A total of 774 new compounds, which were assorted into nine types including terpenes, alkaloids, peptides, aromatics, meroterpenoids, macrolides, polyketides, steroids, and miscellaneous (Figure 49), were reported in the 253 studies in the literature. Among them, the number of the aromatics and the alkaloids takes a percentage of $45 \%$, which suggests that we should pay more attention to the study of these two kinds of compounds.

Natural products isolated from sponge-derived microorganisms have interesting pharmaceutical activities such as cytotoxicity, antioxidant, antifungal, antiviral, and antibacterial activities. Some novel compounds showed significant cytotoxic activities in the $\mathrm{nM}$ levels, such as two new indolocarbazole alkaloids [13] and linear pentadecapeptides efrapeptin E $\alpha$ [29]. Some new compounds exhibited activities stronger than the positive controls. Engyodontochone A-B exhibited inhibitory activity that was 10-fold stronger than chloramphenicol against MRSA [69]. A new pyronepolyene C-glucoside exhibited significant inhibitory effects in the cytopathic effect inhibition assay with an $\mathrm{IC}_{50}$ value of $91.5 \mu \mathrm{M}$ (ribavirin as a positive control, $\mathrm{IC}_{50} 114.8 \mu \mathrm{M}$ ) [86]. Truncateol M showed significant inhibitory effects with an $\mathrm{IC}_{50}$ value of $8.8 \mu \mathrm{M}$ against $\mathrm{H} 1 \mathrm{~N} 1$ virus (oseltamivir as a positive control, $\left.\mathrm{IC}_{50} 46.5 \mu \mathrm{M}\right)$ [101]. Dankastatin C (687) showed potent cell growth inhibitory activity against the murine P388 cell line with an $\mathrm{ED}_{50}$ value of $57 \mathrm{ng} / \mathrm{mL}$ (5-fluorouracil as a positive control, ED $\mathrm{ED}_{50}$, 
$78 \mathrm{ng} / \mathrm{mL}$ ) [236]. As we reported, the diketopiperazine alkaloid amauromine shows affinity for cannabinoid CB1 receptors, which may have potential as a lead structure for drug development [63]. Another noteworthy fact is the discovery of two new compounds-emindole SB betamannoside and 27-O-methylasporyzin C-that may serve as lead structures for the development of GPR18- and $\mathrm{CB}$ receptor-blocking drugs [88]. Compounds isolated from the sponge-derived microorganisms have various activities, and in addition to the above, they also exhibit anti-cholesterol activity [112], antiplasmodial activity [81,134], neuroprotective effects [26,178], and so on. The reported bioactivities are limited by many factors and they are not comprehensive, which suggests that these natural compounds should be screened on a wider variety of bioassays in order to unveil their full potential.

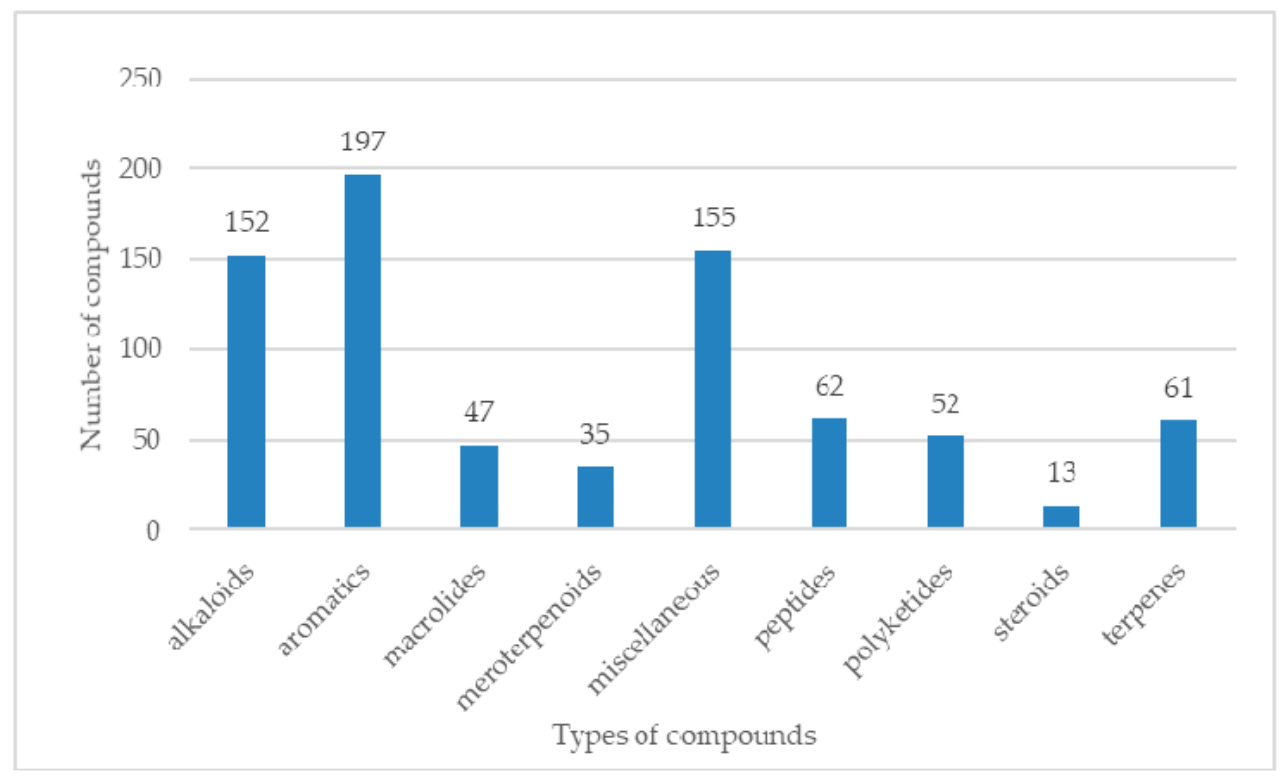

Figure 49. Distribution and activity analysis of natural products from sponge-derived microorganisms based on their putative biogenetic origin.

\section{Conclusions}

A total of 774 new compounds from sponge-derived microorganisms, covering the last two decades from 1998 to 2017, were reviewed. These new compounds presented abundant chemical diversity except for the well-known types such as terpenes, alkaloids, peptides, aromatics, meroterpenoids, macrolides, polyketides, steroids, and so on.

The total amount of new compounds from sponge-derived microorganisms has increased rapidly and has not yet reached a climax, especially in the last five years (see Figure 50). Among the compounds of the sponge-derived microorganisms obtained, more than $42 \%$ of the compounds have detected activities; however, most of them only carried out preliminary active in vitro test experiments.

We should make more efforts to study the pharmacodynamic relationships and pharmacological effects of promising compounds, and conduct clinical trials to complete the drug-like evaluation of the compound. The study on the chemical constituents of sponges and their co-existing microorganisms will promote the study of the relationship between sponges and their co-existing microorganisms, develop and utilize medicinal resources, and systematically study the diversity of biodiversity and ecosystems. Given the structural differences and biodiversity of compounds derived from sponge symbiotic microorganisms, we believe that there are more resources waiting to be mined. 


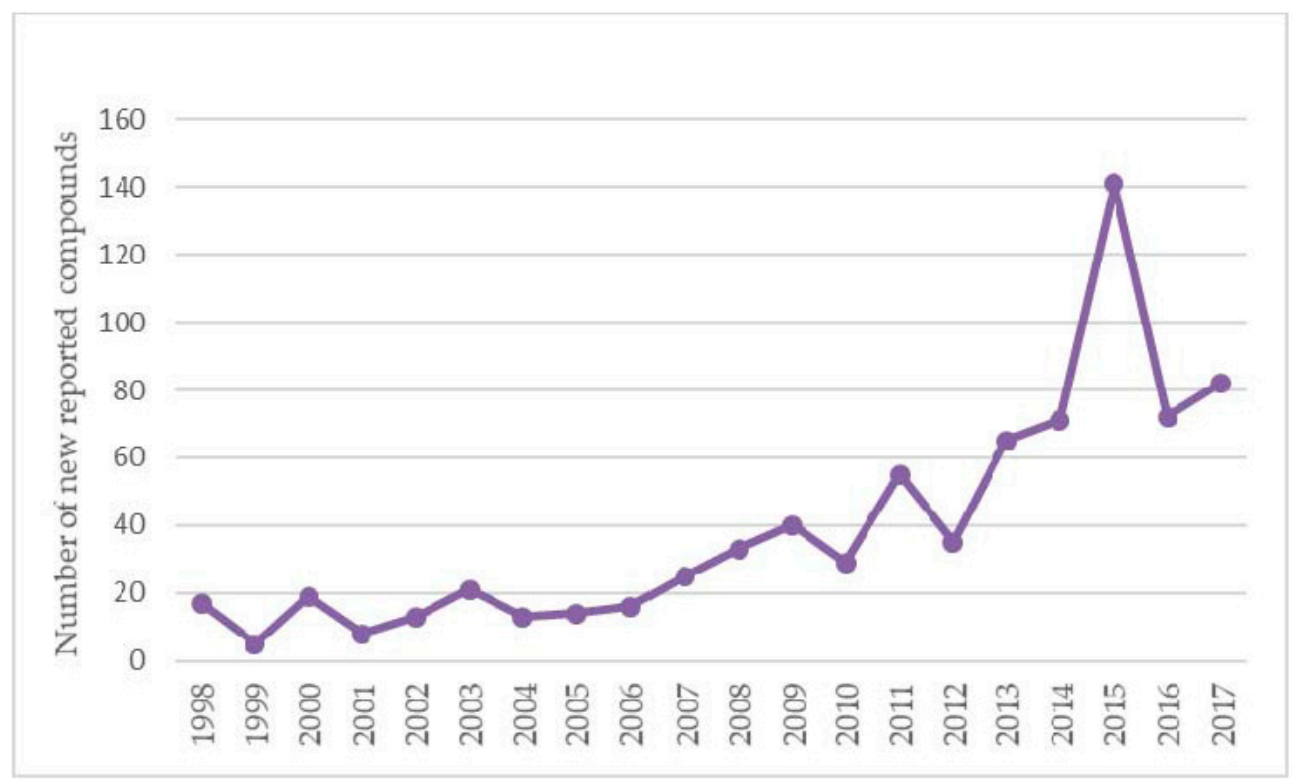

Figure 50. New compounds from sponge-associated microbes in the past two decades.

Author Contributions: G.-Q.L., P.-L.L. and X.-L.T. conceived and designed the review; M.-M.C., D.-Y.S., Y.-J.C. and H.L. collected and searched the references; M.-M.C. and Y.-T.S. provided an effective analysis of the document; M.-M.C. and X.-L.T. conceived and wrote the review. All authors have read and agreed to the published version of the manuscript.

Funding: This work was supported by the National Key Research and Development Program of China (2018YFC0310903), the National Natural Science Foundation of China (Grant No. 21572210 and 41776136), NSFC-Shandong Joint Fund for Marine Science Research Centers (Grant No. U1606403).

Conflicts of Interest: The authors declare no conflict of interest.

\section{References}

1. Douglas, A.E. Symbiotic Interactions; Oxford University Press: Oxford, UK, 1994.

2. Li, Z. Advances in marine microbial symbionts in the China Sea and related pharmaceutical metabolites. Mar. Drugs 2009, 7, 113-129. [CrossRef]

3. Wang, G. Diversity and biotechnological potential of the sponge-associated microbial consortia. J. Ind. Microbiol. Biotechnol. 2006, 33, 545-551. [CrossRef] [PubMed]

4. Proksch, P.; Ebel, R.; Edrada, R.A.; Schupp, P.; Lin, W.H.; Wray, V.; Steube, K. Detection of pharmacologically active natural products using ecology. Selected examples from Indopacific marine invertebrates and sponge-derived fungi. Pure Appl. Chem. 2003, 75, 343-352. [CrossRef]

5. Indraningrat, A.A.; Smidt, H.; Sipkema, D. Bioprospecting Sponge-Associated Microbes for Antimicrobial Compounds. Mar. Drugs 2016, 14, 87. [CrossRef] [PubMed]

6. Zhang, H.; Zhao, Z.; Wang, H. Cytotoxic Natural Products from Marine Sponge-Derived Microorganisms. Mar. Drugs 2017, 15, 68. [CrossRef] [PubMed]

7. Thomas, T.R.; Kavlekar, D.P.; LokaBharathi, P.A. Marine drugs from sponge-microbe association-A review. Mar. Drugs 2010, 8, 1417-1468. [CrossRef]

8. Hardoim, C.C.; Costa, R. Microbial communities and bioactive compounds in marine sponges of the family irciniidae-A review. Mar. Drugs 2014, 12, 5089-5122. [CrossRef]

9. Bibi, F.; Faheem, M.; Azhar, E.I.; Yasir, M.; Alvi, S.A.; Kamal, M.A.; Ullah, I.; Naseer, M.I. Bacteria from Marine Sponges: A Source of New Drugs. Curr. Drug Metab. 2017, 18, 11-15. [CrossRef]

10. Stierle, A.C.; Cardellina, J.H., II; Singleton, F.L. A marine Micrococcus produces metabolites ascribed to the spongetedania ignis. Experientia 1988, 44, 1021. [CrossRef] 
11. Takagi, M.; Motohashi, K.; Shin-ya, K. Isolation of 2 new metabolites, JBIR-74 and JBIR-75, from the sponge-derived Aspergillus sp. fS14. J. Antibiot. 2010, 63, 393-395. [CrossRef]

12. Quévrain, E.; Domart-Coulon, I.; Pernice, M.; Bourguet-Kondracki, M.-L. Novel natural parabens produced by a Microbulbifer bacterium in its calcareous sponge host Leuconia nivea. Environ. Microb. 2009, 11, 1527-1539. [CrossRef] [PubMed]

13. Hernandez, L.M.C.; De la Fuente Blanco, J.A.; Baz, J.P.; Puentes, J.L.F.; Millan, F.R.; Vazquez, F.E.; Fernandez-Chimeno, R.I.; Gravalos, D.G. 4'-N-methyl-5'-hydroxystaurosporine and 5'-hydroxystaurosporine, new indolocarbazole alkaloids from a marine Micromonospora sp. strain. J. Antibiot. 2000, 53, 895-902. [CrossRef] [PubMed]

14. Izumikawa, M.; Khan, S.T.; Komaki, H.; Nagai, A.; Inaba, S.; Takagi, M.; Shin-Ya, K. JBIR-37 and -38, novel glycosyl benzenediols, isolated from the sponge-derived fungus, Acremonium sp. SpF080624G1f01. Biosci. Biotechnol. Biochem. 2009, 73, 2138-2140. [CrossRef] [PubMed]

15. Ueda, J.Y.; Hashimoto, J.; Inaba, S.; Takagi, M.; Shin-Ya, K. JBIR-59, a new sorbicillinoid, from a marine-derived fungus Penicillium citrinum SpI080624G1f01. J. Antibiot. 2010, 63, 203-205. [CrossRef]

16. Kawahara, T.; Takagi, M.; Shin-ya, K. JBIR-124: A novel antioxidative agent from a marine sponge-derived fungus Penicillium citrinum SpI080624G1f01. J. Antibiot. 2012, 65, 45-47. [CrossRef]

17. Ueda, J.-Y.; Khan, S.T.; Takagi, M.; Shin-ya, K. JBIR-58, a new salicylamide derivative, isolated from a marine sponge-derived Streptomyces sp. SpD081030ME-02. J. Antibiot. 2010, 63, 267-269. [CrossRef]

18. Motohashi, K.; Inaba, K.; Fuse, S.; Doi, T.; Izumikawa, M.; Khan, S.T.; Takagi, M.; Takahashi, T.; Shin-ya, K. JBIR-56 and JBIR-57, 2(1H)-Pyrazinones from a Marine Sponge-Derived Streptomyces sp. SpD081030SC-03. J. Nat. Prod. 2011, 74, 1630-1635. [CrossRef]

19. Neumann, K.; Abdel-Lateff, A.; Wright, A.D.; Kehraus, S.; Krick, A.; Koenig, G.M. Novel sorbicillin derivativs with an unprecedented carbon skeleton from the sponge-derived fungus Trichoderma species. Eur. J. Org. Chem. 2007, 24, 4125. [CrossRef]

20. Abdel-Lateff, A.; Fisch, K.; Wright, A.D. Trichopyrone and other constituents from the marine sponge-derived fungus Trichoderma sp. Z. Naturforsch. C J. Biosci. 2009, 64, 186-192. [CrossRef]

21. Ma, X.; Peng, J.; Wu, G.; Zhu, T.; Li, G.; Gu, Q.; Li, D. Speradines B-D, oxygenated cyclopiazonic acid alkaloids from the sponge-derived fungus Aspergillus flavus MXH-X104. Tetrahedron 2015, 71, 3522-3527. [CrossRef]

22. Cheng, C.; Othman, E.M.; Fekete, A.; Krischke, M.; Stopper, H.; Edrada-Ebel, R.; Mueller, M.J.; Hentschel, U.; Abdelmohsen, U.R. Strepoxazine A, a new cytotoxic phenoxazin from the marine sponge-derived bacterium Streptomyces sp. SBT345. Tetrahedron Lett. 2016, 57, 4196-4199. [CrossRef]

23. Cheng, C.; Othman, E.M.; Reimer, A.; Grüne, M.; Kozjak-Pavlovic, V.; Stopper, H.; Hentschel, U.; Abdelmohsen, U.R. Ageloline A, new antioxidant and antichlamydial quinolone from the marine sponge-derived bacterium Streptomyces sp. SBT345. Tetrahedron Lett. 2016, 57, 2786-2789. [CrossRef]

24. Panizel, I.; Yarden, O.; Ilan, M.; Carmeli, S. Eight New Peptaibols from Sponge-Associated Trichoderma atroviride. Mar. Drugs 2013, 11, 4937-4960. [CrossRef] [PubMed]

25. Amagata, T.; Amagata, A.; Tenney, K.; Valeriote, F.A.; Lobkovsky, E.; Clardy, J.; Crews, P. Unusual C25 steroids produced by a sponge-derived Penicillium citrinum. Org. Lett. 2003, 5, 4393-4396. [CrossRef]

26. Hiort, J.; Maksimenka, K.; Reichert, M.; Perovic-Ottstadt, S.; Lin, W.H.; Wray, V.; Steube, K.; Schaumann, K.; Weber, H.; Proksch, P.; et al. New natural products from the sponge-derived fungus Aspergillus niger. J. Nat. Prod. 2004, 67, 1532-1543. [CrossRef]

27. Jadulco, R.; Edrada, R.A.; Ebel, R.; Berg, A.; Schaumann, K.; Wray, V.; Steube, K.; Proksch, P. New communesin derivatives from the fungus Penicillium sp. derived from the Mediterranean sponge Axinella verrucosa. J. Nat. Prod. 2004, 67, 78-81. [CrossRef]

28. Boot, C.M.; Tenney, K.; Valeriote, F.A.; Crews, P. Highly N-methylated linear peptides produced by an atypical sponge-derived Acremonium sp. J. Nat. Prod. 2006, 69, 83-92. [CrossRef]

29. Boot, C.M.; Amagata, T.; Tenney, K.; Compton, J.E.; Pietraszkiewicz, H.; Valeriote, F.A.; Crews, P. Four classes of structurally unusual peptides from two marine-derived fungi: Structures and bioactivities. Tetrahedron 2007, 63, 9903-9914. [CrossRef]

30. Pimentel-Elardo, S.M.; Buback, V.; Gulder, T.A.; Bugni, T.S.; Reppart, J.; Bringmann, G.; Ireland, C.M.; Schirmeister, T.; Hentschel, U. New tetromycin derivatives with anti-trypanosomal and protease inhibitory activities. Mar. Drugs 2011, 9, 1682-1697. [CrossRef] 
31. Ozkaya, F.C.; Bedir, E.; Hames, E.E. A new siderophore from sponge associated Pseudomonas fluorescens 4.9.3. Rec. Nat. Prod. 2015, 9, 509-517.

32. Wu, B.; Ohlendorf, B.; Oesker, V.; Wiese, J.; Malien, S.; Schmaljohann, R.; Imhoff, J.F. Acetylcholinesterase Inhibitors from a Marine Fungus Talaromyces sp. Strain LF458. Mar. Biotechnol. 2015, 17, 110-119. [CrossRef]

33. Küppers, L.; Ebrahim, W.; El-Neketi, M.; Özkaya, F.; Mándi, A.; Kurtán, T.; Orfali, R.; Müller, W.; Hartmann, R.; Lin, W.; et al. Lactones from the Sponge-Derived Fungus Talaromyces rugulosus. Mar. Drugs 2017, 15, 359. [CrossRef]

34. De Castro, M.V.; Ióca, L.P.; Williams, D.E.; Costa, B.Z.; Mizuno, C.M.; Santos, M.F.C.; de Jesus, K.; Ferreira, É.L.F.; Seleghim, M.H.R.; Sette, L.D.; et al. Condensation of Macrocyclic Polyketides Produced by Penicillium sp. DRF2 with Mercaptopyruvate Represents a New Fungal Detoxification Pathway. J. Nat. Prod. 2016, 79, 1668-1678. [CrossRef]

35. Ding, L.-J.; Gu, B.-B.; Jiao, W.-H.; Yuan, W.; Li, Y.-X.; Tang, W.-Z.; Yu, H.-B.; Liao, X.-J.; Han, B.-N.; Li, Z.-Y.; et al. New Furan and Cyclopentenone Derivatives from the Sponge-Associated Fungus Hypocrea Koningii PF04. Mar. Drugs 2015, 13, 5579-5592. [CrossRef]

36. Wang, J.; Wang, Z.; Ju, Z.; Wan, J.; Liao, S.; Lin, X.; Zhang, T.; Zhou, X.; Chen, H.; Tu, Z.; et al. Cytotoxic Cytochalasins from Marine-Derived Fungus Arthrinium arundinis. Planta Med. 2015, 81, 160-166. [CrossRef]

37. Wang, J.; Wei, X.; Qin, X.; Lin, X.; Zhou, X.; Liao, S.; Yang, B.; Liu, J.; Tu, Z.; Liu, Y. Arthpyrones A-C, pyridone alkaloids from a sponge-derived fungus Arthrinium arundinis ZSDS1-F3. Org. Lett. 2015, 17, 656-659. [CrossRef]

38. Li, Y.; Wang, J.; He, W.; Lin, X.; Zhou, X.; Liu, Y. One Strain-Many Compounds Method for Production of Polyketide Metabolites Using the Sponge-Derived Fungus Arthrinium arundinis ZSDS1-F3. Chem. Nat. Compd. 2017, 53, 373-374. [CrossRef]

39. Zhang, J.; Lin, X.-P.; Li, L.-C.; Zhong, B.-L.; Liao, X.-J.; Liu, Y.-H.; Xu, S.-H. Gliomasolides A-E, unusual macrolides from a sponge-derived fungus Gliomastix sp. ZSDS1-F7-2. RSC Adv. 2015, 5, 54645-54648. [CrossRef]

40. Ding, L.-J.; Yuan, W.; Li, Y.-X.; Liao, X.-J.; Sun, H.; Peng, Q.; Han, B.-N.; Lin, H.-W.; Li, Z.-Y.; Yang, F.; et al. Hypocrol A, a new tyrosol derivative from a sponge-derived strain of the fungus Hypocrea koningii. Nat. Prod. Res. 2016, 30, 1633-1638. [CrossRef]

41. Ding, L.-J.; Yuan, W.; Liao, X.-J.; Han, B.-N.; Wang, S.-P.; Li, Z.-Y.; Xu, S.-H.; Zhang, W.; Lin, H.-W. Oryzamides A-E, Cyclodepsipeptides from the Sponge-Derived Fungus Nigrospora oryzae PF18. J. Nat. Prod. 2016, 79, 2045-2052. [CrossRef]

42. Gu, B.-B.; Tang, J.; Wang, S.-P.; Sun, F.; Yang, F.; Li, L.; Xu, Y.; Lin, H.-W. Structure, absolute configuration, and variable-temperature $1 \mathrm{H}-\mathrm{NMR}$ study of $( \pm)$-versiorcinols $\mathrm{A}-\mathrm{C}$, three racemates of diorcinol monoethers from the sponge-associated fungus Aspergillus versicolor 16F-11. RSC Adv. 2017, 7, 50254-50263. [CrossRef]

43. Lei, H.; Lin, X.; Han, L.; Ma, J.; Dong, K.; Wang, X.; Zhong, J.; Mu, Y.; Liu, Y.; Huang, X. Polyketide derivatives from a marine-sponge-associated fungus Pestalotiopsis heterocornis. Phytochemistry 2017, 142, 51-59. [CrossRef] [PubMed]

44. Lei, H.; Lin, X.; Han, L.; Ma, J.; Ma, Q.; Zhong, J.; Liu, Y.; Sun, T.; Wang, J.; Huang, X. New Metabolites and Bioactive Chlorinated Benzophenone Derivatives Produced by a Marine-Derived Fungus Pestalotiopsis heterocornis. Mar. Drugs 2017, 15, 69. [CrossRef]

45. Mohamed, I.E.; Gross, H.; Pontius, A.; Kehraus, S.; Krick, A.; Kelter, G.; Maier, A.; Fiebig, H.-H.; Konig, G.M. Epoxyphomalin A and B, prenylated polyketides with potent cytotoxicity from the marine-derived fungus Phoma sp. Org. Lett. 2009, 11, 5014-5017. [CrossRef] [PubMed]

46. Prompanya, C.; Dethoup, T.; Bessa, L.; Pinto, M.; Gales, L.; Costa, P.; Silva, A.; Kijjoa, A. New Isocoumarin Derivatives and Meroterpenoids from the Marine Sponge-Associated Fungus Aspergillus similanensis sp. nov. KUFA 0013. Mar. Drugs 2014, 12, 5160-5173. [CrossRef] [PubMed]

47. Wyche, T.P.; Hou, Y.; Braun, D.; Cohen, H.C.; Xiong, M.P.; Bugni, T.S. First Natural Analogs of the Cytotoxic Thiodepsipeptide Thiocoraline A from a Marine Verrucosispora sp. J. Org. Chem. 2011, 76, 6542-6547. [CrossRef] [PubMed]

48. Gomes, N.M.; Bessa, L.J.; Buttachon, S.; Costa, P.M.; Buaruang, J.; Dethoup, T.; Silva, A.M.; Kijjoa, A. Antibacterial and antibiofilm activities of tryptoquivalines and meroditerpenes isolated from the marine-derived fungi Neosartorya paulistensis, N. laciniosa, N. tsunodae, and the soil fungi N. fischeri and N. siamensis. Mar. Drugs 2014, 12, 822-839. [CrossRef] 
49. Liu, S.; Dai, H.; Konuklugil, B.; Orfali, R.S.; Lin, W.; Kalscheuer, R.; Liu, Z.; Proksch, P. Phenolic bisabolanes from the sponge-derived fungus Aspergillus sp. Phytochem. Lett. 2016, 18, 187-191. [CrossRef]

50. Lang, G.; Wiese, J.; Schmaljohann, R.; Imhoff, J.F. New pentaenes from the sponge-derived marine fungus Penicillium rugulosum: Structure determination and biosynthetic studies. Tetrahedron 2007, 63, 11844-11849. [CrossRef]

51. San-Martin, A.; Rovirosa, J.; Vaca, I.; Vergara, K.; Acevedo, L.; Vina, D.; Orallo, F.; Chamy, C. New butyrolactone from a marine-derived fungus Aspergillus sp. J. Chil. Chem. Soc. 2011, 56, 625-627. [CrossRef]

52. Eltamany, E.E.; Abdelmohsen, U.R.; Ibrahim, A.K.; Hassanean, H.A.; Hentschel, U.; Ahmed, S.A. New antibacterial xanthone from the marine sponge-derived Micrococcus sp. EG45. Bioorg. Med. Chem. Lett. 2014, 24, 4939-4942. [CrossRef] [PubMed]

53. Abdelmohsen, U.; Cheng, C.; Viegelmann, C.; Zhang, T.; Grkovic, T.; Ahmed, S.; Quinn, R.; Hentschel, U.; Edrada-Ebel, R. Dereplication Strategies for Targeted Isolation of New Antitrypanosomal Actinosporins A and B from a Marine Sponge Associated-Actinokineospora sp. EG49. Mar. Drugs 2014, 12, 1220-1244. [CrossRef]

54. Grkovic, T.; Abdelmohsen, U.R.; Othman, E.M.; Stopper, H.; Edrada-Ebel, R.; Hentschel, U.; Quinn, R.J. Two new antioxidant actinosporin analogues from the calcium alginate beads culture of sponge-associated Actinokineospora sp. strain EG49. Bioorg. Med. Chem. Lett. 2014, 24, 5089-5092. [CrossRef]

55. Dashti, Y.; Grkovic, T.; Abdelmohsen, U.R.; Hentschel, U.; Quinn, R.J. Actinomycete Metabolome Induction/Suppression with N-Acetylglucosamine. J. Nat. Prod. 2017, 80, 828-836. [CrossRef] [PubMed]

56. Jeon, J.-E.; Julianti, E.; Oh, H.; Park, W.; Oh, D.-C.; Oh, K.-B.; Shin, J. Stereochemistry of hydroxy-bearing benzolactones: Isolation and structural determination of chrysoarticulins $\mathrm{A}-\mathrm{C}$ from a marine-derived fungus Chrysosporium articulatum. Tetrahedron Lett. 2013, 54, 3111-3115. [CrossRef]

57. De Rosa, S.; De Giulio, A.; Tommonaro, G.; Popov, S.; Kujumgiev, A. A $\beta$-amino acid containing tripeptide from a Pseudomonas-Alteromonas bacterium associated with a Black Sea sponge. J. Nat. Prod. 2000, 63, 1454-1455. [CrossRef]

58. Yu, L.-L.; Li, Z.-Y.; Peng, C.-S.; Li, Z.-Y.; Guo, Y.-W. Neobacillamide A, a novel thiazole-containing alkaloid from the marine bacterium Bacillus atrophaeus C89, associated with South China Sea sponge Dysidea avara. Helv. Chim. Acta 2009, 92, 607-612. [CrossRef]

59. Abdelmohsen, U.R.; Zhang, G.; Philippe, A.; Schmitz, W.; Pimentel-Elardo, S.M.; Hertlein-Amslinger, B.; Hentschel, U.; Bringmann, G. Cyclodysidins A-D, cyclic lipopeptides from the marine sponge-derived Streptomyces strain RV15. Tetrahedron Lett. 2012, 53, 23-29. [CrossRef]

60. Mitova, M.; Tommonaro, G.; De Rosa, S. A novel cyclopeptide from a bacterium associated with the marine sponge Ircinia muscarum. Z. Naturforsch. C J. Biosci. 2003, 58, 740-745. [CrossRef]

61. Bringmann, G.; Lang, G.; Gulder, T.A.M.; Tsuruta, H.; Mühlbacher, J.; Maksimenka, K.; Steffens, S.; Schaumann, K.; Stöhr, R.; Wiese, J.; et al. The first sorbicillinoid alkaloids, the antileukemic sorbicillactones A and B, from a sponge-derived Penicillium chrysogenum strain. Tetrahedron 2005, 61, 7252-7265. [CrossRef]

62. Bringmann, G.; Lang, G.; Bruhn, T.; Schäffler, K.; Steffens, S.; Schmaljohann, R.; Wiese, J.; Imhoff, J.F. Sorbifuranones A-C, sorbicillinoid metabolites from Penicillium strains isolated from Mediterranean sponges. Tetrahedron 2010, 66, 9894-9901. [CrossRef]

63. Elsebai, M.F.; Rempel, V.; Schnakenburg, G.; Kehraus, S.; Müller, C.E.; König, G.M. Identification of a Potent and Selective Cannabinoid CB1 Receptor Antagonist from Auxarthron reticulatum. ACS Med. Chem. Lett. 2011, 2, 866-869. [CrossRef] [PubMed]

64. Nazir, M.; Harms, H.; Loef, I.; Kehraus, S.; El Maddah, F.; Arslan, I.; Rempel, V.; Müller, C.; König, G. GPR18 Inhibiting Amauromine and the Novel Triterpene Glycoside Auxarthonoside from the Sponge-Derived Fungus Auxarthron reticulatum. Planta Med. 2015, 81, 1141-1145. [CrossRef] [PubMed]

65. Koch, L.; Lodin, A.; Herold, I.; Ilan, M.; Carmeli, S.; Yarden, O. Sensitivity of Neurospora crassa to a Marine-Derived Aspergillus tubingensis Anhydride Exhibiting Antifungal Activity That Is Mediated by the MAS1 Protein. Mar. Drugs 2014, 12, 4713-4731. [CrossRef]

66. Chen, H.; Aktas, N.; Konuklugil, B.; Mándi, A.; Daletos, G.; Lin, W.; Dai, H.; Kurtán, T.; Proksch, P. A new fusarielin analogue from Penicillium sp. isolated from the Mediterranean sponge Ircinia oros. Tetrahedron Lett. 2015, 56, 5317-5320. [CrossRef] 
67. Cohen, E.; Koch, L.; Thu, K.M.; Rahamim, Y.; Aluma, Y.; Ilan, M.; Yarden, O.; Carmeli, S. Novel terpenoids of the fungus Aspergillus insuetus isolated from the Mediterranean sponge Psammocinia sp. collected along the coast of Israel. Bioorg. Med. Chem. 2011, 19, 6587-6593. [CrossRef]

68. Elissawy, A.M.; Ebada, S.S.; Ashour, M.L.; Özkaya, F.C.; Ebrahim, W.; Singab, A.B.; Proksch, P. Spiroarthrinols A and B, two novel meroterpenoids isolated from the sponge-derived fungus Arthrinium sp. Phytochem. Lett. 2017, 20, 246-251. [CrossRef]

69. Wu, B.; Wiese, J.; Wenzel-Storjohann, A.; Malien, S.; Schmaljohann, R.; Imhoff, J.F. Engyodontochones, Antibiotic Polyketides from the Marine Fungus Engyodontium album Strain LF069. Chemistry 2016, 22, 7452-7462. [CrossRef]

70. Speitling, M.; Smetanina, O.F.; Kuznetsova, T.A.; Laatsch, H. Bromoalterochromides A and A', unprecedented chromopeptides from a marine Pseudoalteromonas maricaloris strain KMM 636T. J. Antibiot. 2007, 60, 36-42. [CrossRef]

71. Varoglu, M.; Crews, P. Biosynthetically diverse compounds from a saltwater culture of sponge-derived Aspergillus niger. J. Nat. Prod. 2000, 63, 41-43. [CrossRef]

72. Pinheiro, Â.; Dethoup, T.; Bessa, J.; Silva, A.M.S.; Kijjoa, A. A new bicyclic sesquiterpene from the marine sponge associated fungus Emericellopsis minima. Phytochem. Lett. 2012, 5, 68-70. [CrossRef]

73. Asiri, I.A.M.; Badr, J.M.; Youssef, D.T.A. Penicillivinacine, antimigratory diketopiperazine alkaloid from the marine-derived fungus Penicillium vinaceum. Phytochem. Lett. 2015, 13, 53-58. [CrossRef]

74. Li, B.; Huang, Q.-X.; Gao, D.; Liu, D.; Ji, Y.-B.; Liu, H.-G.; Lin, W.-H. New C13lipids from the marine-derived fungus Trichoderma harzianum. J. Asian Nat. Prod. Res. 2015, 17, 468-474. [CrossRef] [PubMed]

75. Hu, K.-C.; Xu, M.-Y.; Li, H.-J.; Yuan, J.; Tang, G.; Xu, J.; Yang, D.-P.; Lan, W.-J. Discovery of aromadendrane anologues from the marine-derived fungus Scedosporium dehoogii F41-4 by NMR-guided isolation. RSC Adv. 2016, 6, 94763-94770. [CrossRef]

76. Cao, Q.-X.; Wei, J.-H.; Deng, R.; Feng, G.-K.; Zhu, X.-F.; Lan, W.-J.; Li, H.-J. Two New Pyripyropenes from the Marine Fungus Fusarium lateritium 2016F18-1. Chem. Biodivers. 2017, 14, e1600298. [CrossRef] [PubMed]

77. Edrada, R.A.; Wray, V.; Berg, A.; Grafe, U.; Sudarsono; Brauers, G.; Proksch, P. Novel spiciferone derivatives from the fungus Drechslera hawaiiensis isolated from the marine sponge Callyspongia aerizusa. Z. Naturforsch. C J. Biosci. 2000, 55, 218-221. [CrossRef]

78. Jadulco, R.; Proksch, P.; Wray, V.; Sudarsono; Berg, A.; Graefe, U. New Macrolides and Furan Carboxylic Acid Derivative from the Sponge-Derived Fungus Cladosporium herbarum. J. Nat. Prod. 2001, 64, 527-530. [CrossRef]

79. Jadulco, R.; Brauers, G.; Edrada, R.A.; Ebel, R.; Wray, V.; Sudarsono; Proksch, P. New metabolites from sponge-derived fungi Curvularia lunata and Cladosporium herbarum. J. Nat. Prod. 2002, 65, 730-733. [CrossRef]

80. Choi, E.J.; Kwon, H.C.; Ham, J.; Yang, H.O. 6-Hydroxymethyl-1-phenazine-carboxamide and 1,6-phenazinedimethanol from a marine bacterium, Brevibacterium sp. KMD 003, associated with marine purple vase sponge. J. Antibiot. 2009, 62, 621-624. [CrossRef]

81. Almeida, C.; Kehraus, S.; Prudêncio, M.; König, G.M. Marilones A-C, phthalides from the sponge-derived fungus Stachylidium sp. Beilstein J. Org. Chem. 2011, 7, 1636-1642. [CrossRef]

82. Almeida, C.; Part, N.; Bouhired, S.; Kehraus, S.; Koenig, G.M. Stachylines A-D from the sponge-derived fungus Stachylidium sp. J. Nat. Prod. 2011, 74, 21-25. [CrossRef] [PubMed]

83. Almeida, C.; Hemberger, Y.; Schmitt, S.M.; Bouhired, S.; Natesan, L.; Kehraus, S.; Dimas, K.; Gutschow, M.; Bringmann, G.; Konig, G.M. Marilines A-C: Novel phthalimidines from the sponge-derived fungus Stachylidium sp. Chemistry 2012, 18, 8827-8834. [CrossRef] [PubMed]

84. Almeida, C.; Eguereva, E.; Kehraus, S.; Koenig, G.M. Unprecedented polyketides from a marine sponge-associated Stachylidium sp. J. Nat. Prod. 2013, 76, 322-326. [CrossRef] [PubMed]

85. Almeida, C.; Maddah, F.E.; Kehraus, S.; Schnakenburg, G.; König, G.M. Endolides A and B, Vasopressin and Serotonin-Receptor Interacting N-Methylated Peptides from the Sponge-Derived Fungus Stachylidium sp. Org. Lett. 2016, 18, 528-531. [CrossRef]

86. Peng, J.; Jiao, J.; Li, J.; Wang, W.; Gu, Q.; Zhu, T.; Li, D. Pyronepolyene C-glucosides with NF-kB inhibitory and anti-influenza A viral (H1N1) activities from the sponge-associated fungus Epicoccum sp. JJY40. Bioorg. Med. Chem. Lett. 2012, 22, 3188-3190. [CrossRef] 
87. Zhang, G.; Wu, G.; Zhu, T.; Kurtán, T.; Mándi, A.; Jiao, J.; Li, J.; Qi, X.; Gu, Q.; Li, D. Meroterpenoids with Diverse Ring Systems from the Sponge-Associated Fungus Alternaria sp. JJY-32. J. Nat. Prod. 2013, 76, 1946-1957. [CrossRef]

88. Harms, H.; Rempel, V.; Kehraus, S.; Kaiser, M.; Hufendiek, P.; Muller, C.E.; Konig, G.M. Indoloditerpenes from a marine-derived fungal strain of Dichotomomyces cejpii with antagonistic activity at GPR18 and cannabinoid receptors. J. Nat. Prod. 2014, 77, 673-677. [CrossRef]

89. Harms, H.; Kehraus, S.; Nesaei-Mosaferan, D.; Hufendieck, P.; Meijer, L.; Koenig, G.M. A $\beta-42$ lowering agents from the marine-derived fungus Dichotomomyces cejpii. Steroids 2015, 104, 182-188. [CrossRef]

90. Harms, H.; Orlikova, B.; Ji, S.; Nesaei-Mosaferan, D.; Konig, G.M.; Diederich, M. Epipolythiodiketopiperazines from the Marine Derived Fungus Dichotomomyces cejpii with NF-kappaB Inhibitory Potential. Mar. Drugs 2015, 13, 4949-4966. [CrossRef]

91. El Maddah, F.; Kehraus, S.; Nazir, M.; Almeida, C.; König, G.M. Insights into the Biosynthetic Origin of 3-(3-Furyl) alanine in Stachylidium sp. 293 K04 Tetrapeptides. J. Nat. Prod. 2016, 79, 2838-2845. [CrossRef]

92. Tian, Y.-Q.; Lin, X.-P.; Wang, Z.; Zhou, X.-F.; Qin, X.-C.; Kaliyaperumal, K.; Zhang, T.-Y.; Tu, Z.-C.; Liu, Y. Asteltoxins with antiviral activities from the marine sponge-derived fungus Aspergillus sp. SCSIO XWS02F40. Molecules 2016, 21, 34. [CrossRef] [PubMed]

93. Sperry, S.; Samuels, G.J.; Crews, P. Vertinoid Polyketides from the Saltwater Culture of the Fungus Trichoderma longibrachiatum Separated from a Haliclona Marine Sponge. J. Org. Chem. 1998, 63, 10011-10014. [CrossRef]

94. Wang, G.-Y.-S.; Abrell, L.M.; Avelar, A.; Borgeson, B.M.; Crews, P. New hirsutane-based sesquiterpenes from salt water cultures of a marine sponge-derived fungus and the terrestrial fungus Coriolus consors. Tetrahedron 1998, 54, 7335-7342. [CrossRef]

95. Bringmann, G.; Lang, G.; Steffens, S.; Günther, E.; Schaumann, K. Evariquinone, isoemericellin, and stromemycin from a sponge derived strain of the fungus Emericella variecolor. Phytochemistry 2003, 63, 437-443. [CrossRef]

96. Pimentel-Elardo, S.M.; Gulder, T.A.M.; Hentschel, U.; Bringmann, G. Cebulactams A1 and A2, new macrolactams isolated from Saccharopolyspora cebuensis, the first obligate marine strain of the genus Saccharopolyspora. Tetrahedron Lett. 2008, 49, 6889-6892. [CrossRef]

97. Izumikawa, M.; Khan, S.T.; Komaki, H.; Takagi, M.; Shin-ya, K. JBIR-31, a new teleocidin analog, produced by salt-requiring Streptomyces sp. NBRC 105896 isolated from a marine sponge. J. Antibiot. 2010, 63, 33-36. [CrossRef]

98. Motohashi, K.; Takagi, M.; Shin-ya, K. Tetrapeptides possessing a unique skeleton, JBIR-34 and JBIR-35, isolated from a sponge-derived actinomycete, Streptomyces sp. Sp080513GE-23. J. Nat. Prod. 2010, 73, 226-228. [CrossRef]

99. Motohashi, K.; Takagi, M.; Shin-ya, K. Tetracenoquinocin and 5-iminoaranciamycin from a sponge-derived Streptomyces sp. Sp080513GE-26. J. Nat. Prod. 2010, 73, 755-758. [CrossRef]

100. Izumikawa, M.; Kawahara, T.; Hwang, J.-H.; Takagi, M.; Shin-ya, K. JBIR-107, a new metabolite from the marine-sponge-derived actinomycete, Streptomyces tateyamensis NBRC 105047. Biosci. Biotechnol. Biochem. 2013, 77, 663-665. [CrossRef]

101. Zhao, Y.; Si, L.; Liu, D.; Proksch, P.; Zhou, D.; Lin, W. Truncateols A-N, new isoprenylated cyclohexanols from the sponge-associated fungus Truncatella angustata with anti-H1N1 virus activities. Tetrahedron 2015, 71, 2708-2718. [CrossRef]

102. Zhao, Y.; Liu, D.; Proksch, P.; Yu, S.; Lin, W. Angupyrones A-E, $\alpha$-Pyrone Analogues with ARE-Activation from a Sponge-Associated Fungus Truncatella angustata. Chem. Biodivers. 2017, 14, e1700236. [CrossRef]

103. Zhao, Y.; Liu, D.; Proksch, P.; Yu, S.; Lin, W. Isocoumarin Derivatives from the Sponge-Associated Fungus Peyronellaea glomerate with Antioxidant Activities. Chem. Biodivers. 2016, 13, 1186-1193. [CrossRef]

104. Zhu, H.; Hua, X.-x.; Gong, T.; Pang, J.; Hou, Q.; Zhu, P. Hypocreaterpenes A and B, cadinane-type sesquiterpenes from a marine-derived fungus, Hypocreales sp. Phytochem. Lett. 2013, 6, 392-396. [CrossRef] 
105. Gong, T.; Zhen, X.; Li, B.-J.; Yang, J.-L.; Zhu, P. Two new monoterpenoid $\alpha$-pyrones from a fungus Nectria sp. HLS206 associated with the marine sponge Gelliodes carnosa. J. Asian Nat. Prod. Res. 2015, 17, 633-637. [CrossRef]

106. Zhen, X.; Gong, T.; Liu, F.; Zhang, P.-C.; Zhou, W.-Q.; Li, Y.; Zhu, P. A New Analogue of Echinomycin and a New Cyclic Dipeptide from a Marine-Derived Streptomyces sp. LS298. Mar. Drugs 2015, 13, 6947-6961. [CrossRef]

107. Gesner, S.; Cohen, N.; Ilan, M.; Yarden, O.; Carmeli, S. Pandangolide 1a, a metabolite of the sponge-associated fungus Cladosporium sp., and the absolute stereochemistry of pandangolide 1 and iso-cladospolide B. J. Nat. Prod. 2005, 68, 1350-1353. [CrossRef]

108. Li, Y.; Liu, D.; Cen, S.; Proksch, P.; Lin, W. Isoindolinone-type alkaloids from the sponge-derived fungus Stachybotrys chartarum. Tetrahedron 2014, 70, 7010-7015. [CrossRef]

109. Li, Y.; Wu, C.; Liu, D.; Proksch, P.; Guo, P.; Lin, W. Chartarlactams A-P, phenylspirodrimanes from the sponge-associated fungus Stachybotrys chartarum with antihyperlipidemic activities. J. Nat. Prod. 2014, 77, 138-147. [CrossRef]

110. Li, Y.; Liu, D.; Cheng, Z.; Proksch, P.; Lin, W. Cytotoxic trichothecene-type sesquiterpenes from the sponge-derived fungus Stachybotrys chartarum with tyrosine kinase inhibition. RSC Adv. 2017, 7, 7259-7267. [CrossRef]

111. Liu, D.; Li, Y.; Li, X.; Cheng, Z.; Huang, J.; Proksch, P.; Lin, W. Chartarolides A-C, novel meroterpenoids with antitumor activities. Tetrahedron Lett. 2017, 58, 1826-1829. [CrossRef]

112. Wu, Z.; Liu, D.; Proksch, P.; Guo, P.; Lin, W. Punctaporonins H-M: Caryophyllene-Type Sesquiterpenoids from the Sponge-Associated Fungus Hansfordia sinuosae. Mar. Drugs 2014, 12, 3904-3916. [CrossRef]

113. Wu, Z.; Li, Y.; Liu, D.; Ma, M.; Chen, J.; Lin, W. New Resorcinol Derivatives from a Sponge-Derived Fungus Hansfordia sinuosae. Chem. Biodivers. 2017, 14, e1700059. [CrossRef] [PubMed]

114. Wu, Z.-H.; Li, Y.; Li, Y.; Ma, M.; Chen, J.-L. Salicylic acid derivatives and phenylspirodrimanes from the sponge-associated fungus Hansfordia sinuosae. J. Asian Nat. Prod. Res. 2018, 20, 985-991. [CrossRef] [PubMed]

115. Bringmann, G.; Lang, G.; Steffens, S.; Schaumann, K. Petrosifungins A and B, novel cyclodepsipeptides from a sponge-derived strain of Penicillium brevicompactum. J. Nat. Prod. 2004, 67, 311-315. [CrossRef] [PubMed]

116. Elbandy, M.; Shinde, P.B.; Dang, H.T.; Hong, J.; Bae, K.S.; Jung, J.H. Furan metabolites from the sponge-derived yeast Pichia membranifaciens. J. Nat. Prod. 2008, 71, 869-872. [CrossRef] [PubMed]

117. Elbandy, M.; Shinde, P.B.; Hong, J.; Bae, K.S.; Kim, M.A.; Lee, S.M.; Jung, J.H. $\alpha$-pyrones and yellow pigments from the sponge-derived fungus Paecilomyces lilacinus. Bull. Korean Chem. Soc. 2009, 30, 188-192.

118. Lopez-Gresa, M.P.; Cabedo, N.; Gonzalez-Mas, M.C.; Ciavatta, M.L.; Avila, C.; Primo, J. Terretonins E and F, Inhibitors of the Mitochondrial Respiratory Chain from the Marine-Derived Fungus Aspergillus insuetus. J. Nat. Prod. 2009, 72, 1348-1351. [CrossRef]

119. Lee, Y.-M.; Dang, H.T.; Hong, J.-K.; Lee, C.-O.; Bae, K.-S.; Kim, D.-K.; Jung, J.-H. A Cytotoxic Lipopeptide from the Sponge-Derived Fungus Aspergillus versicolor. Bull. Korean Chem. Soc. 2010, 31, 205-208. [CrossRef]

120. Lee, Y.-M.; Dang, H.T.; Li, J.; Zhang, P.; Hong, J.-K.; Lee, C.-O.; Jung, J.-H. A Cytotoxic Fellutamide Analogue from the Sponge-Derived Fungus Aspergillus versicolor. Bull. Korean Chem. Soc. 2011, 32, 3817-3820. [CrossRef]

121. Li, J.L.; Huang, L.; Liu, J.; Song, Y.; Gao, J.; Jung, J.H.; Liu, Y.; Chen, G. Acetylcholinesterase inhibitory dimeric indole derivatives from the marine actinomycetes Rubrobacter radiotolerans. Fitoterapia 2015, 102, 203-207. [CrossRef]

122. Li, J.; Chen, D.; Huang, L.; Ni, M.; Zhao, Y.; Fan, H.; Bao, X. Antichlamydial Dimeric Indole Derivatives from Marine Actinomycete Rubrobacter radiotolerans. Planta Med. 2017, 83, 805-811. [CrossRef]

123. Buttachon, S.; May Zin, W.W.; Dethoup, T.; Gales, L.; Pereira, J.A.; Silva, A.M.; Kijjoa, A. Secondary Metabolites from the Culture of the Marine Sponge-Associated Fungi Talaromyces tratensis and Sporidesmium circinophorum. Planta Med. 2016, 82, 888-896. [CrossRef]

124. Lin, W.H.; Li, J.; Fu, H.Z.; Proksch, P. Four novel hydropyranoindeno-derivatives from marine fungus Aspergillus versicolor. Chin. Chem. Lett. 2001, 12, 435-438.

125. Edrada, R.A.; Heubes, M.; Brauers, G.; Wray, V.; Berg, A.; Graefe, U.; Wohlfarth, M.; Muehlbacher, J.; Schaumann, K.; Bringmann, G.; et al. Online analysis of xestodecalactones A-C, novel bioactive metabolites from the fungus Penicillium cf. montanense and their subsequent isolation from the sponge Xestospongia exigua. J. Nat. Prod. 2002, 65, 1598-1604. 
126. Lin, W.; Brauers, G.; Ebel, R.; Wray, V.; Berg, A.; Sudarsono; Proksch, P. Novel chromone derivatives from the fungus Aspergillus versicolor isolated from the marine sponge Xestospongia exigua. J. Nat. Prod. 2003, 66, 57-61. [CrossRef]

127. Ingavat, N.; Dobereiner, J.; Wiyakrutta, S.; Mahidol, C.; Ruchirawat, S.; Kittakoop, P. Aspergillusol A, an $\alpha$-Glucosidase Inhibitor from the Marine-Derived Fungus Aspergillus aculeatus. J. Nat. Prod. 2009, 72, 2049-2052. [CrossRef]

128. Ingavat, N.; Mahidol, C.; Ruchirawat, S.; Kittakoop, P. Asperaculin A, a sesquiterpenoid from a marine-derived fungus, Aspergillus aculeatus. J. Nat. Prod. 2011, 74, 1650-1652. [CrossRef]

129. Li, D.; Xu, Y.; Shao, C.-L.; Yang, R.-Y.; Zheng, C.-J.; Chen, Y.-Y.; Fu, X.-M.; Qian, P.-Y.; She, Z.-G.; Voogd, N.J.; et al. Antibacterial Bisabolane-Type Sesquiterpenoids from the Sponge-Derived Fungus Aspergillus sp. Mar. Drugs 2012, 10, 234-241. [CrossRef]

130. Sun, L.L.; Shao, C.L.; Chen, J.F.; Guo, Z.Y.; Fu, X.M.; Chen, M.; Chen, Y.Y.; Li, R.; de Voogd, N.J.; She, Z.G.; et al. New bisabolane sesquiterpenoids from a marine-derived fungus Aspergillus sp. isolated from the sponge Xestospongia testudinaria. Bioorg. Med. Chem. Lett. 2012, 22, 1326-1329. [CrossRef]

131. Supong, K.; Thawai, C.; Suwanborirux, K.; Choowong, W.; Supothina, S.; Pittayakhajonwut, P. Antimalarial and antitubercular C-glycosylated benz $[\alpha]$ anthraquinones from the marine-derived Streptomyces $\mathrm{sp}$. BCC45596. Phytochem. Lett. 2012, 5, 651-656. [CrossRef]

132. Ma, X.; Li, L.; Zhu, T.; Ba, M.; Li, G.; Gu, Q.; Guo, Y.; Li, D. Phenylspirodrimanes with Anti-HIV Activity from the Sponge-Derived Fungus Stachybotrys chartarum MXH-X73. J. Nat. Prod. 2013, 76, 2298-2306. [CrossRef] [PubMed]

133. Ma, X.; Wang, H.; Li, F.; Zhu, T.; Gu, Q.; Li, D. Stachybotrin G, a sulfate meroterpenoid from a sponge derived fungus Stachybotrys chartarum MXH-X73. Tetrahedron Lett. 2015, 56, 7053-7055. [CrossRef]

134. Harinantenaina Rakotondraibe, L.; Rasolomampianina, R.; Park, H.-Y.; Li, J.; Slebodnik, C.; Brodie, P.J.; Blasiak, L.C.; Hill, R.; TenDyke, K.; Shen, Y.; et al. Antiproliferative and antiplasmodial compounds from selected Streptomyces species. Bioorg. Med. Chem. Lett. 2015, 25, 5646-5649. [CrossRef]

135. Bugni, T.S.; Bernan, V.S.; Greenstein, M.; Janso, J.E.; Maiese, W.M.; Mayne, C.L.; Ireland, C.M. Brocaenols A-C: Novel Polyketides from a Marine-Derived Penicillium brocae. J. Org. Chem. 2003, 68, 6846. [CrossRef]

136. Prompanya, C.; Dethoup, T.; Gales, L.; Lee, M.; Pereira, J.; Silva, A.; Pinto, M.; Kijjoa, A. New Polyketides and New Benzoic Acid Derivatives from the Marine Sponge-Associated Fungus Neosartorya quadricincta KUFA 0081. Mar. Drugs 2016, 14, 134. [CrossRef]

137. Kumla, D.; Shine Aung, T.; Buttachon, S.; Dethoup, T.; Gales, L.; Pereira, J.; Inácio, Â.; Costa, P.; Lee, M.; Sekeroglu, N.; et al. A New Dihydrochromone Dimer and Other Secondary Metabolites from Cultures of the Marine Sponge-Associated Fungi Neosartorya fennelliae KUFA 0811 and Neosartorya tsunodae KUFC 9213. Mar. Drugs 2017, 15, 375. [CrossRef]

138. Christian, O.E.; Compton, J.; Christian, K.R.; Mooberry, S.L.; Valeriote, F.A.; Crews, P. Using jasplakinolide to turn on pathways that enable the isolation of new chaetoglobosins from Phomospis asparagi. J. Nat. Prod. 2005, 68, 1592-1597. [CrossRef]

139. Xin, Z.H.; Zhu, W.M.; Gu, Q.Q.; Fang, Y.C.; Duan, L.; Cui, C.B. A new cytotoxic compound from Penicillium auratiogriseum, symbiotic or epiphytic fungus of sponge Mycale plumose. Chin. Chem. Lett. 2005, 16, 1227-1229.

140. Xin, Z.H.; Fang, Y.; Du, L.; Zhu, T.; Duan, L.; Chen, J.; Gu, Q.-Q.; Zhu, W.-M. Aurantiomides A-C, quinazoline alkaloids from the sponge-derived fungus Penicillium aurantiogriseum SP0-19. J. Nat. Prod. 2007, 70, 853-855. [CrossRef]

141. Feher, D.; Barlow, R.S.; Lorenzo, P.S.; Hemscheidt, T.K. A 2-substituted prodiginine, 2- (p-hydroxybenzyl) prodigiosin, from Pseudoalteromonas rubra. J. Nat. Prod. 2008, 71, 1970-1972. [CrossRef]

142. Motohashi, K.; Inaba, S.; Takagi, M.; Shin-ya, K. JBIR-15, a new aspochracin derivative, isolated from a sponge-derived fungus, Aspergillus sclerotiorum Huber Sp080903f04. Biosci. Biotechnol. Biochem. 2009, 73, 1898-1900. [CrossRef]

143. Gomes, N.M.; Dethoup, T.; Singburaudom, N.; Gales, L.; Silva, A.M.S.; Kijjoa, A. Eurocristatine, a new diketopiperazine dimer from the marine sponge-associated fungus Eurotium cristatum. Phytochem. Lett. 2012, 5, 717-720. [CrossRef]

144. May Zin, W.; Buttachon, S.; Dethoup, T.; Fernandes, C.; Cravo, S.; Pinto, M.; Gales, L.; Pereira, J.; Silva, A.; Sekeroglu, N.; et al. New Cyclotetrapeptides and a New Diketopiperzine Derivative from the Marine Sponge-Associated Fungus Neosartorya glabra KUFA 0702. Mar. Drugs 2016, 14, 136. [CrossRef] [PubMed] 
145. Neumann, K.; Kehraus, S.; Guetschow, M.; Koenig, G.M. Cytotoxic and HLE-inhibitory tetramic acid derivatives from marine-derived fungi. Nat. Prod. Commun. 2009, 4, 347-354. [CrossRef] [PubMed]

146. Vicente, J.; Stewart, A.; van Wagoner, R.; Elliott, E.; Bourdelais, A.; Wright, J. Monacyclinones, New Angucyclinone Metabolites Isolated from Streptomyces sp. M7_15 Associated with the Puerto Rican Sponge Scopalinaruetzleri. Mar. Drugs 2015, 13, 4682-4700. [CrossRef]

147. Antia, B.S.; Aree, T.; Kasettrathat, C.; Wiyakrutta, S.; Ekpa, O.D.; Ekpe, U.J.; Mahidol, C.; Ruchirawat, S.; Kittakoop, P. Itaconic acid derivatives and diketopiperazine from the marine-derived fungus Aspergillus aculeatus CRI322-03. Phytochemistry 2011, 72, 816-820. [CrossRef]

148. Noinart, J.; Buttachon, S.; Dethoup, T.; Gales, L.; Pereira, J.; Urbatzka, R.; Freitas, S.; Lee, M.; Silva, A.; Pinto, M.; et al. A New Ergosterol Analog, a New Bis-Anthraquinone and Anti-Obesity Activity of Anthraquinones from the Marine Sponge-Associated Fungus Talaromyces stipitatus KUFA 0207. Mar. Drugs 2017, 15, 139. [CrossRef]

149. Leman-Loubière, C.; Le Goff, G.; Retailleau, P.; Debitus, C.; Ouazzani, J. Sporothriolide-Related Compounds from the Fungus Hypoxylon monticulosum CLL-205 Isolated from a Sphaerocladina Sponge from the Tahiti Coast. J. Nat. Prod. 2017, 80, 2850-2854. [CrossRef]

150. Amagata, T.; Doi, M.; Ohta, T.; Minoura, K.; Numata, A. Absolute stereostructures of novel cytotoxic metabolites, gymnastatins A-E, from a Gymnascella species separated from a Halichondria sponge. J. Chem. Soc. Perkin Trans. 1 1998, 21, 3585-3600. [CrossRef]

151. Amagata, T.; Minoura, K.; Numata, A. Gymnasterones, novel cytotoxic metabolite produced by a fungal strain from sponge. Tetrahedron Lett. 1998, 39, 3773-3774. [CrossRef]

152. Amagata, T.; Minoura, K.; Numata, A. Gymnastatins F-H, cytostatic metabolites from the sponge-derived fungus Gymnascella dankaliensis. J. Nat. Prod. 2006, 69, 1384-1388. [CrossRef] [PubMed]

153. Numata, A.; Amagata, T.; Takigawa, K.; Minoura, K. Gymnastatins I-K, Cancer Cell Growth Inhibitors from a Sponge-Derived Gymnascella dankaliensis. Heterocycles 2010, 81, 897.

154. Amagata, T.; Doi, M.; Tohgo, M.; Minoura, K.; Numata, A. Dankasterone, a new class of cytotoxic steroid produced by a Gymnascella species from a marine sponge. Chem. Commun. 1999, 14, 1321-1322. [CrossRef]

155. Amagata, T.; Tanaka, M.; Yamada, T.; Doi, M.; Minoura, K.; Ohishi, H.; Yamori, T.; Numata, A. Variation in cytostatic constituents of a sponge-derived Gymnascella dankaliensis by manipulating the carbon source. J. Nat. Prod. 2007, 70, 1731-1740. [CrossRef]

156. Amagata, T.; Tanaka, M.; Yamada, T.; Minoura, K.; Numata, A. Gymnastatins and dankastatins, growth inhibitory metabolites of a Gymnascella species from a Halichondria sponge. J. Nat. Prod. 2008, 71, 340-345. [CrossRef]

157. Amagata, T.; Usami, Y.; Minoura, K.; Ito, T.; Numata, A. Cytotoxic substances produced by a fungal strain from a sponge: Physico-chemical properties and structures. J. Antibiot. 1998, 51, 33-40. [CrossRef]

158. Wicke, C.; Hueners, M.; Wray, V.; Nimtz, M.; Bilitewski, U.; Lang, S. Production and structure elucidation of glycoglycerolipids from a marine sponge-associated Microbacterium species. J. Nat. Prod. 2000, 63, 621-626. [CrossRef]

159. Nagai, K.; Kamigiri, K.; Arao, N.; Suzumura, K.-I.; Kawano, Y.; Yamaoka, M.; Zhang, H.; Watanabe, M.; Suzuki, K. YM-266183 and YM-266184, novel thiopeptide antibiotics produced by Bacillus cereus isolated from a marine sponge. I. Taxonomy, fermentation, isolation, physico-chemical properties and biological properties. J. Antibiot. 2003, 56, 123-128. [CrossRef]

160. Adachi, K.; Kanoh, K.; Wisespongp, P.; Nishijima, M.; Shizuri, Y. Clonostachysins A and B, new anti-dinoflagellate cyclic peptides from a marine-derived fungus. J. Antibiot. 2005, 58, 145-150. [CrossRef]

161. Mitova, M.I.; Lang, G.; Wiese, J.; Imhoff, J.F. Subinhibitory concentrations of antibiotics induce phenazine production in a marine Streptomyces sp. J. Nat. Prod. 2008, 71, 824-827. [CrossRef]

162. Schneemann, I.; Kajahn, I.; Ohlendorf, B.; Zinecker, H.; Erhard, A.; Nagel, K.; Wiese, J.; Imhoff, J.F. Mayamycin, a Cytotoxic Polyketide from a Streptomyces Strain Isolated from the Marine Sponge Halichondria panicea. J. Nat. Prod. 2010, 73, 1309-1312. [CrossRef] [PubMed]

163. Kunz, A.; Labes, A.; Wiese, J.; Bruhn, T.; Bringmann, G.; Imhoff, J. Nature's Lab for Derivatization: New and Revised Structures of a Variety of Streptophenazines Produced by a Sponge-Derived Streptomyces Strain. Mar. Drugs 2014, 12, 1699-1714. [CrossRef] [PubMed] 
164. Zhang, D.; Yang, X.; Kang, J.S.; Choi, H.D.; Son, B.W. Chlorohydroaspyrones A and B, antibacterial aspyrone derivatives from the marine-derived fungus Exophiala sp. J. Nat. Prod. 2008, 71, 1458-1460. [CrossRef] [PubMed]

165. Sugiyama, Y.; Ito, Y.; Suzuki, M.; Hirota, A. Indole derivatives from a marine sponge-derived yeast as DPPH radical scavengers. J. Nat. Prod. 2009, 72, 2069-2071. [CrossRef]

166. Schneemann, I.; Ohlendorf, B.; Zinecker, H.; Nagel, K.; Wiese, J.; Imhoff, J.F. Nocapyrones A-D, $\gamma$-Pyrones from a Nocardiopsis Strain Isolated from the Marine Sponge Halichondria panicea. J. Nat. Prod. 2010, 73, 1444-1447. [CrossRef]

167. Yamada, T.; Mizutani, Y.; Umebayashi, Y.; Inno, N.; Kawashima, M.; Kikuchi, T.; Tanaka, R. Tandyukisin, a novel ketoaldehyde decalin derivative, produced by a marine sponge-derived Trichoderma harzianum. Tetrahedron Lett. 2014, 55, 662-664. [CrossRef]

168. Yamada, T.; Umebayashi, Y.; Kawashima, M.; Sugiura, Y.; Kikuchi, T.; Tanaka, R. Determination of the Chemical Structures of Tandyukisins B-D, Isolated from a Marine Sponge-Derived Fungus. Mar. Drugs 2015, 13, 3231-3240. [CrossRef]

169. Suzue, M.; Kikuchi, T.; Tanaka, R.; Yamada, T. Tandyukisins E and F, novel cytotoxic decalin derivatives isolated from a marine sponge-derived fungus. Tetrahedron Lett. 2016, 57, 5070-5073. [CrossRef]

170. Yamada, T.; Suzue, M.; Arai, T.; Kikuchi, T.; Tanaka, R. Trichodermanins C-E, New Diterpenes with a Fused 6-5-6-6 Ring System Produced by a Marine Sponge-Derived Fungus. Mar. Drugs 2017, 15, 169. [CrossRef]

171. Wu, B.; Wiese, J.; Labes, A.; Kramer, A.; Schmaljohann, R.; Imhoff, J. Lindgomycin, an Unusual Antibiotic Polyketide from a Marine Fungus of the Lindgomycetaceae. Mar. Drugs 2015, 13, 4617-4632. [CrossRef]

172. Li, K.; Li, Q.-L.; Ji, N.-Y.; Liu, B.; Zhang, W.; Cao, X.-P. Deoxyuridines from the Marine Sponge Associated Actinomycete Streptomyces microflavus. Mar. Drugs 2011, 9, 690-695. [CrossRef] [PubMed]

173. Wei, R.-B.; Xi, T.; Li, J.; Wang, P.; Li, F.-C.; Lin, Y.-C.; Qin, S. Lobophorin C and D, New Kijanimicin Derivatives from a Marine Sponge-Associated Actinomycetal Strain AZS17. Mar. Drugs 2011, 9, 359-368. [CrossRef] [PubMed]

174. Song, F.; Ren, B.; Chen, C.; Yu, K.; Liu, X.; Zhang, Y.; Yang, N.; He, H.; Liu, X.; Dai, H.; et al. Three new sterigmatocystin analogues from marine-derived fungus Aspergillus versicolor MF359. Appl. Microbiol. Biot. 2014, 98, 3753-3758. [CrossRef] [PubMed]

175. Wang, X.; Mou, Y.; Hu, J.; Wang, N.; Zhao, L.; Liu, L.; Wang, S.; Meng, D. Cytotoxic polyphenols from a sponge-associated fungus Aspergillus versicolor Hmp-48. Chem. Biodivers. 2014, 11, 133-139. [CrossRef] [PubMed]

176. Figueroa, L.; Jiménez, C.; Rodríguez, J.; Areche, C.; Chávez, R.; Henríquez, M.; de la Cruz, M.; Díaz, C.; Segade, Y.; Vaca, I. 3-Nitroasterric Acid Derivatives from an Antarctic Sponge-Derived Pseudogymnoascus sp. Fungus. J. Nat. Prod. 2015, 78, 919-923. [CrossRef] [PubMed]

177. Yan, B.F.; Fang, S.T.; Li, W.Z.; Liu, S.J.; Wang, J.H.; Xia, C.H. A new minor diketopiperazine from the sponge-derived fungus Simplicillium sp. YZ-11. Nat. Prod. Res. 2015, 29, 2013-2017. [CrossRef] [PubMed]

178. Fang, F.; Zhao, J.; Ding, L.; Huang, C.; Naman, C.B.; He, S.; Wu, B.; Zhu, P.; Luo, Q.; Gerwick, W.H.; et al. 5-Hydroxycyclopenicillone, a New $\beta$-Amyloid Fibrillization Inhibitor from a Sponge-Derived Fungus Trichoderma sp. HPQJ-34. Mar. Drugs 2017, 15, 260. [CrossRef]

179. Mitova, M.; Popov, S.; De Rosa, S. Cyclic peptides from a Ruegeria strain of bacteria associated with the sponge Suberites domuncula. J. Nat. Prod. 2004, 67, 1178-1181. [CrossRef]

180. Liu, H.; Edrada-Ebel, R.; Ebel, R.; Wang, Y.; Schulz, B.; Draeger, S.; Muller, W.E.G.; Wray, V.; Lin, W.; Proksch, P. Drimane sesquiterpenoids from the fungus Aspergillus ustus isolated from the marine sponge Suberites domuncula. J. Nat. Prod. 2009, 72, 1585-1588. [CrossRef]

181. Liu, H.-B.; Edrada-Ebel, R.; Ebel, R.; Wang, Y.; Schulz, B.; Draeger, S.; Mueller, W.E.G.; Wray, V.; Lin, W.-H.; Proksch, P. Ophiobolin Sesterterpenoids and Pyrrolidine Alkaloids from the Sponge-Derived Fungus Aspergillus ustus. Helv. Chim. Acta 2011, 94, 623-631. [CrossRef]

182. Simmons, L.; Kaufmann, K.; Garcia, R.; Schwär, G.; Huch, V.; Müller, R. Bendigoles D-F, bioactive sterols from the marine sponge-derived Actinomadura sp. SBMs009. Bioorg. Med. Chem. 2011, 19, 6570-6575. [CrossRef] [PubMed]

183. Kim, H.; Yang, I.; Ryu, S.-Y.; Won, D.H.; Giri, A.G.; Wang, W.; Choi, H.; Chin, J.; Hahn, D.; Kim, E.; et al. Acredinones A and B, Voltage-Dependent Potassium Channel Inhibitors from the Sponge-Derived Fungus Acremonium sp. F9A015. J. Nat. Prod. 2015, 78, 363-367. [CrossRef] [PubMed] 
184. Yu, Z.; Lang, G.; Kajahn, I.; Schmaljohann, R.; Imhoff, J.F. Scopularides A and B, cyclodepsipeptides from a marine sponge-derived fungus, Scopulariopsis brevicaulis. J. Nat. Prod. 2008, 71, 1052-1054. [CrossRef] [PubMed]

185. Wiese, J.; Ohlendorf, B.; Blümel, M.; Schmaljohann, R.; Imhoff, J.F. Phylogenetic Identification of Fungi Isolated from the Marine Sponge Tethya aurantium and Identification of Their Secondary Metabolites. Mar. Drugs 2011, 9, 561-585. [CrossRef] [PubMed]

186. Jansen, N.; Ohlendorf, B.; Erhard, A.; Bruhn, T.; Bringmann, G.; Imhoff, J. Helicusin E, Isochromophilone X and Isochromophilone XI: New Chloroazaphilones Produced by the Fungus Bartalinia robillardoides Strain LF550. Mar. Drugs 2013, 11, 800-816. [CrossRef] [PubMed]

187. Zhou, Y.; Debbab, A.; Wray, V.; Lin, W.; Schulz, B.; Trepos, R.; Pile, C.; Hellio, C.; Proksch, P.; Aly, A.H. Marine bacterial inhibitors from the sponge-derived fungus Aspergillus sp. Tetrahedron Lett. 2014, 55, 2789-2792. [CrossRef]

188. Julianti, E.; Oh, H.; Jang, K.H.; Lee, J.K.; Lee, S.K.; Oh, D.-C.; Oh, K.-B.; Shin, J. Acremostrictin, a Highly Oxygenated Metabolite from the Marine Fungus Acremonium strictum. J. Nat. Prod. 2011, 74, 2592-2594. [CrossRef]

189. Julianti, E.; Oh, H.; Lee, H.-S.; Oh, D.-C.; Oh, K.-B.; Shin, J. Acremolin, a new 1H-azirine metabolite from the marine-derived fungus Acremonium strictum. Tetrahedron Lett. 2012, 53, 2885-2886. [CrossRef]

190. Rahbk, L.; Sperry, S.; Piper, J.E.; Crews, P. Deoxynortrichoharzin, a new polyketide from the saltwater culture of a sponge-derived Paecilomyces fungus. J. Nat. Prod. 1998, 61, 1571-1573. [CrossRef]

191. Li, H.; Shinde, P.B.; Lee, H.J.; Yoo, E.S.; Lee, C.-O.; Hong, J.; Choi, S.H.; Jung, J.H. Bile acid derivatives from a sponge-associated bacterium Psychrobacter sp. Arch. Pharm. Res. 2009, 32, 857-862. [CrossRef]

192. Zhang, P.; Bao, B.; Dang, H.T.; Hong, J.; Lee, H.J.; Yoo, E.S.; Bae, K.S.; Jung, J.H. Anti-inflammatory sesquiterpenoids from a sponge-derived fungus Acremonium sp. J. Nat. Prod. 2009, 72, 270-275. [CrossRef] [PubMed]

193. Li, H.; Li, J.; Lee, C.-O.; Bae, K.S.; Hong, J.; Jung, J.H. Indole oligomers from a marine sponge-associated bacterium Psychrobacter sp. Biochem. Syst. Ecol. 2010, 38, 839-841. [CrossRef]

194. Li, J.L.; Zhang, P.; Lee, Y.M.; Hong, J.; Yoo, E.S.; Bae, K.S.; Jung, J.H. Oxygenated hexylitaconates from a marine sponge-derived fungus Penicillium sp. Chem. Pharm. Bull. 2011, 59, 120-123. [CrossRef]

195. Liu, S.; Wang, H.; Su, M.; Hwang, G.J.; Hong, J.; Jung, J.H. New metabolites from the sponge-derived fungus Aspergillus sydowii J05B-7F-4. Nat. Prod. Res. 2017, 31, 1682-1686. [CrossRef] [PubMed]

196. Ebada, S.S.; Schulz, B.; Wray, V.; Totzke, F.; Kubbutat, M.H.G.; Müller, W.E.G.; Hamacher, A.; Kassack, M.U.; Lin, W.; Proksch, P. Arthrinins A-D: Novel diterpenoids and further constituents from the sponge derived fungus Arthrinium sp. Bioorg. Med. Chem. 2011, 19, 4644-4651. [CrossRef] [PubMed]

197. Bultel-Ponce, V.; Berge, J.-P.; Debitus, C.; Nicolas, J.-L.; Guyot, M. Metabolites from the sponge-associated bacterium Pseudomonas species. Mar. Biotechnol. 1999, 1, 384-390. [CrossRef] [PubMed]

198. Kanoh, K.; Kamino, K.; Leleo, G.; Adachi, K.; Shizuri, Y. Pseudoalterobactin A and B, new siderophores excreted by marine bacterium Pseudoalteromonas sp. KP20-4. J. Antibiot. 2003, 56, 871-875. [CrossRef]

199. Izumikawa, M.; Khan, S.T.; Takagi, M.; Shin-ya, K. Sponge-derived Streptomyces producing isoprenoids via the mevalonate pathway. J. Nat. Prod. 2010, 73, 208-212. [CrossRef]

200. Wu, Q.; Wu, C.; Long, H.; Chen, R.; Liu, D.; Proksch, P.; Guo, P.; Lin, W. Varioxiranols A-G and 19-O-Methyl-22-methoxypre-shamixanthone, PKS and Hybrid PKS-Derived Metabolites from a Sponge-Associated Emericella variecolor Fungus. J. Nat. Prod. 2015, 78, 2461-2470. [CrossRef]

201. Wu, Q.; Long, H.-L.; Liu, D.; Proksch, P.; Lin, W.-H. Varioxiranols I-L, new lactones from a sponge-associated Emericella variecolor fungus. J. Asian Nat. Prod. Res. 2015, 17, 1137-1145. [CrossRef]

202. Long, H.; Cheng, Z.; Huang, W.; Wu, Q.; Li, X.; Cui, J.; Proksch, P.; Lin, W. Diasteltoxins A-C, Asteltoxin-Based Dimers from a Mutant of the Sponge-Associated Emericella variecolor Fungus. Org. Lett. 2016, 18, 4678-4681. [CrossRef] [PubMed]

203. Huang, X.-L.; Gao, Y.; Xue, D.-Q.; Liu, H.-L.; Peng, C.-S.; Zhang, F.-L.; Li, Z.-Y.; Guo, Y.-W. Streptomycindole, an indole alkaloid from a marine Streptomyces sp. DA22 associated with South China Sea sponge Craniella australiensis. Helv. Chim. Acta 2011, 94, 1838-1842. [CrossRef]

204. Okada, M.; Sugita, T.; Wong, C.P.; Wakimoto, T.; Abe, I. Identification of Pyridinium with Three Indole Moieties as an Antimicrobial Agent. J. Nat. Prod. 2017, 80, 1205-1209. [CrossRef] [PubMed] 
205. Chen, Y.-H.; Lu, M.-C.; Chung, H.-M.; Weng, C.-F.; Su, J.-H.; Yang, Y.-T.; Su, Y.-D.; Chang, Y.-C.; Kuo, J.; $\mathrm{Wu}$, Y.-C.; et al. Bafilomycin M, a new cytotoxic bafilomycin produced by a Streptomyces sp. isolated from a marine sponge Theonella sp. Tetrahedron Lett. 2016, 57, 4863-4865. [CrossRef]

206. Brauers, G.; Edrada, R.A.; Ebel, R.; Proksch, P.; Wray, V.; Berg, A.; Graefe, U.; Schaechtele, C.; Totzke, F.; Finkenzeller, G.; et al. Anthraquinones and betaenone derivatives from the sponge-associated fungus Microsphaeropsis species: Novel inhibitors of protein kinases. J. Nat. Prod. 2000, 63, 739-745. [CrossRef]

207. Wang, C.-Y.; Wang, B.-G.; Brauers, G.; Guan, H.-S.; Proksch, P.; Ebel, R. Microsphaerones A and B, two novel $\gamma$-pyrone derivatives from the sponge-derived fungus Microsphaeropsis sp. J. Nat. Prod. 2002, 65, 772-775. [CrossRef]

208. Brauers, G.; Ebel, R.; Edrada, R.; Wray, V.; Berg, A.; Graefe, U.; Proksch, P. Hortein, a new natural product from the fungus Hortaea werneckii associated with the sponge Aplysina aerophoba. J. Nat. Prod. 2001, 64, 651-652. [CrossRef]

209. Sun, D.; Sun, W.; Yu, Y.; Li, Z.; Deng, Z.; Lin, S. A new glutarimide derivative from marine sponge-derived Streptomyces anulatus S71. Nat. Prod. Res. 2014, 28, 1602-1606. [CrossRef]

210. Suciati; Fraser, J.A.; Lambert, L.K.; Pierens, G.K.; Bernhardt, P.V.; Garson, M.J. Secondary Metabolites of the Sponge-Derived Fungus Acremonium persicinum. J. Nat. Prod. 2013, 76, 1432-1440. [CrossRef]

211. Amagata, T.; Morinaka, B.I.; Amagata, A.; Tenney, K.; Valeriote, F.A.; Lobkovsky, E.; Clardy, J.; Crews, P. A chemical study of cyclic depsipeptides produced by a sponge-derived fungus. J. Nat. Prod. 2006, 69, 1560-1565. [CrossRef]

212. Ueda, J.-y.; Takagi, M.; Shin-ya, K. New xanthoquinodin-like compounds, JBIR-97, -98 and -99, obtained from marine sponge-derived fungus Tritirachium sp. SpB081112MEf2. J. Antibiot. 2010, 63, 615-618. [CrossRef] [PubMed]

213. Shigemori, H.; Tenma, M.; Shimazaki, K.; Kobayashi, J.i. Three New Metabolites from the Marine Yeast Aureobasidium pullulans. J. Nat. Prod. 1998, 61, 696-698. [CrossRef] [PubMed]

214. Smith, C.J.; Abbanat, D.; Bernan, V.S.; Maiese, W.M.; Greenstein, M.; Jompa, J.; Tahir, A.; Ireland, C.M. Novel polyketide metabolites from a species of marine fungi. J. Nat. Prod. 2000, 63, 142-145. [CrossRef] [PubMed]

215. Ui, H.; Shiomi, K.; Yamaguchi, Y.; Masuma, R.; Nagamitsu, T.; Takano, D.; Sunazuka, T.; Namikoshi, M.; Omura, S. Nafuredin, a novel inhibitor of NADH-fumarate reductase, produced by Aspergillus niger FT-0554. J. Antibiot. 2001, 54, 234-238. [CrossRef]

216. Malmstrom, J.; Christophersen, C.; Barrero, A.F.; Oltra, J.E.; Justicia, J.; Rosales, A. Bioactive metabolites from a marine-derived strain of the fungus Emericella variecolor. J. Nat. Prod. 2002, 65, 364-367. [CrossRef]

217. Namikoshi, M.; Negishi, R.; Nagai, H.; Dmitrenok, A.; Kobayashi, H. Three new chlorine containing antibiotics from a marine-derived fungus Aspergillus ostianus collected in Pohnpei. J. Antibiot. 2003, 56, 755-761. [CrossRef]

218. Ookura, R.; Kito, K.; Ooi, T.; Namikoshi, M.; Kusumi, T. Structure Revision of Circumdatins A and B, Benzodiazepine Alkaloids Produced by Marine Fungus Aspergillus ostianus, by X-ray Crystallography. J. Org. Chem. 2008, 73, 4245-4247. [CrossRef]

219. Kito, K.; Ookura, R.; Yoshida, S.; Namikoshi, M.; Ooi, T.; Kusumi, T. New cytotoxic 14-membered macrolides from marine-derived fungus Aspergillus ostianus. Org. Lett. 2008, 10, 225-228. [CrossRef]

220. Kito, K.; Ookura, R.; Kusumi, T.; Namikoshi, M.; Ooi, T. X-ray structures of two stephacidins, heptacyclic alkaloids from the marine-derived fungus Aspergillus ostianus. Heterocycles 2009, 78, 2101-2106. [CrossRef]

221. Kong, F.; Singh, M.P.; Carter, G.T. Pseudopyronines A and B, $\alpha$-pyrones produced by a marine Pseudomonas sp. F92S91, and evidence for the conversion of 4-hydroxy- $\alpha$-pyrone to 3-furanone. J. Nat. Prod. 2005, 68, 920-923. [CrossRef]

222. Lee, H.-S.; Shin, H.J.; Jang, K.H.; Kim, T.S.; Oh, K.-B.; Shin, J. Cyclic Peptides of the Nocardamine Class from a Marine-Derived Bacterium of the Genus Streptomyces. J. Nat. Prod. 2005, 68, 623-625. [CrossRef]

223. Cruz, L.J.; Martinez Insua, M.; Perez Baz, J.; Trujillo, M.; Rodriguez-Mias, R.A.; Oliveira, E.; Giralt, E.; Albericio, F.; Canedo, L.M. IB-01212, a new cytotoxic cyclodepsipeptide isolated from the marine fungus Clonostachys sp. ESNA-A009. J. Org. Chem. 2006, 71, 3335-3338. [CrossRef]

224. Cueto, M.; MacMillan, J.B.; Jensen, P.R.; Fenical, W. Tropolactones A-D, four meroterpenoids from a marine-derived fungus of the genus Aspergillus. Phytochemistry 2006, 67, 1826-1831. [CrossRef] 
225. Tsukamoto, S.; Yoshida, T.; Hosono, H.; Ohta, T.; Yokosawa, H. Hexylitaconic acid: A new inhibitor of p53-HDM2 interaction isolated from a marine-derived fungus, Arthrinium sp. Bioorg. Med. Chem. Lett. 2006, 16, 69-71. [CrossRef]

226. Xu, J.; Takasaki, A.; Kobayashi, H.; Oda, T.; Yamada, J.; Mangindaan, R.E.P.; Ukai, K.; Nagai, H.; Namikoshi, M. Four new macrocyclic trichothecenes from two strains of marine-derived fungi of the genus Myrothecium. J. Antibiot. 2006, 59, 451-455. [CrossRef]

227. Hao, G.; Qing-Hua, Z.; Miao-Miao, J.; Jin-Shan, T.; Cheng-Du, M.; Kui, H.; Michio, N.; Nai-Li, W.; Xin-Sheng, Y. Polyketides from a marine sponge-derived fungus Mycelia sterilia and proton-proton long-range coupling. Magn. Reson. Chem. 2008, 46, 1148-1152. [CrossRef]

228. You, M.-X.; Zhang, H.-P.; Hu, C.-Q. Isolation and characterization of three siderophores from marine bacteria. Chin. J. Chem. 2008, 26, 1332-1334. [CrossRef]

229. Zhao, L.L.; Gai, Y.; Kobayashi, H.; Hu, C.Q.; Zhang, H.P. 5'-Hydroxyzearalenol, a new $\beta$-resorcylic macrolide from Fusarium sp. 05ABR26. Chin. Chem. Lett. 2008, 19, 1089-1092. [CrossRef]

230. Pruksakorn, P.; Arai, M.; Kotoku, N.; Vilchèze, C.; Baughn, A.D.; Moodley, P.; Jacobs, W.R.; Kobayashi, M. Trichoderins, novel aminolipopeptides from a marine sponge-derived Trichoderma sp., are active against dormant mycobacteria. Bioorg. Med. Chem. Lett. 2010, 20, 3658-3663. [CrossRef]

231. Takagi, M.; Motohashi, K.; Khan, S.T.; Hashimoto, J.; Shin-ya, K. JBIR-65, a new diterpene, isolated from a sponge-derived Actinomadura sp. SpB081030SC-15. J. Antibiot. 2010, 63, 401-403. [CrossRef]

232. Hosoya, T.; Hirokawa, T.; Takagi, M.; Shin-ya, K. Trichostatin Analogues JBIR-109, JBIR-110, and JBIR-111 from the Marine Sponge-Derived Streptomyces sp. RM72. J. Nat. Prod. 2012, 75, 285-289. [CrossRef] [PubMed]

233. Kawahara, T.; Takagi, M.; Shin-ya, K. Three new depsipeptides, JBIR-113, JBIR-114 and JBIR-115, isolated from a marine sponge-derived Penicillium sp. fS36. J. Antibiot. 2012, 65, 147-150. [CrossRef] [PubMed]

234. Sureram, S.; Wiyakrutta, S.; Ngamrojanavanich, N.; Mahidol, C.; Ruchirawat, S.; Kittakoop, P. Depsidones, aromatase inhibitors and radical scavenging agents from the marine-derived fungus Aspergillus unguis CRI282-03. Planta Med. 2012, 78, 582-588. [CrossRef] [PubMed]

235. Yamazaki, H.; Rotinsulu, H.; Kaneko, T.; Murakami, K.; Fujiwara, H.; Ukai, K.; Namikoshi, M. A New Dibenz[b,e]oxepine Derivative, 1-Hydroxy-10-methoxy-dibenz[b,e]oxepin-6,11-dione, from a Marine-Derived Fungus, Beauveria bassiana TPU942. Mar. Drugs 2012, 10, 2691-2697. [CrossRef]

236. Amagata, T.; Tanaka, M.; Yamada, T.; Chen, Y.-P.; Minoura, K.; Numata, A. Additional cytotoxic substances isolated from the sponge-derived Gymnascella dankaliensis. Tetrahedron Lett. 2013, 54, 5960-5962. [CrossRef]

237. Kong, X.; Ma, X.; Xie, Y.; Cai, S.; Zhu, T.; Gu, Q.; Li, D. Aromatic polyketides from a sponge-derived fungus Metarhizium anisopliae mxh-99 and their antitubercular activities. Arch. Pharm. Res. 2013, 36, 739-744. [CrossRef]

238. Martin, J.; Crespo, G.; Palomo, S.; Gonzalez, I.; Tormo, J.R.; de la Cruz, M.; Anderson, M.; Hill, R.T.; Vicente, F.; Genilloud, O.; et al. Kocurin, the true structure of PM181104, an anti-methicillin-resistant Staphylococcus aureus (MRSA) thiazolyl peptide from the marine-derived bacterium Kocuria palustris. Mar. Drugs 2013, 11, 387-398. [CrossRef]

239. Mosadeghzad, Z.; Zuriati, Z.; Asmat, A.; Gires, U.; Wickneswari, R.; Pittayakhajonwut, P.; Farahani, G.H.N. Chemical components and bioactivity of the marine-derived fungus Paecilomyces sp. collected from Tinggi Island, Malaysia. Chem. Nat. Compd. 2013, 49, 621-625. [CrossRef]

240. Qi, J.; Shao, C.-L.; Li, Z.-Y.; Gan, L.-S.; Fu, X.-M.; Bian, W.-T.; Zhao, H.-Y.; Wang, C.-Y. Isocoumarin Derivatives and Benzofurans from a Sponge-Derived Penicillium sp. Fungus. J. Nat. Prod. 2013, 76, 571-579. [CrossRef]

241. Kim, M.C.; Hwang, E.; Kim, T.; Ham, J.; Kim, S.Y.; Kwon, H.C. Nocatriones A and B, Photoprotective Tetracenediones from a Marine-Derived Nocardiopsis sp. J. Nat. Prod. 2014, 77, 2326-2330. [CrossRef]

242. Kotoku, N.; Higashimoto, K.; Kurioka, M.; Arai, M.; Fukuda, A.; Sumii, Y.; Sowa, Y.; Sakai, T.; Kobayashi, M. Xylarianaphthol-1, a novel dinaphthofuran derivative, activates p21 promoter in a p53-independent manner. Bioorg. Med. Chem. Lett. 2014, 24, 3389-3391. [CrossRef] [PubMed]

243. Kwon, Y.; Kim, S.-H.; Shin, Y.; Bae, M.; Kim, B.-Y.; Lee, S.; Oh, K.-B.; Shin, J.; Oh, D.-C. A New Benzofuran Glycoside and Indole Alkaloids from a Sponge-Associated Rare Actinomycete, Amycolatopsis sp. Mar. Drugs 2014, 12, 2326-2340. [CrossRef] [PubMed] 
244. Liu, Y.; Li, X.-M.; Meng, L.-H.; Wang, B.-G. N-Formyllapatin A, a new N-formylspiroquinazoline derivative from the marine-derived fungus Penicillium adametzioides AS-53. Phytochem. Lett. 2014, 10, 145-148. [CrossRef]

245. Liu, Y.; Li, X.-M.; Meng, L.-H.; Jiang, W.-L.; Xu, G.-M.; Huang, C.-G.; Wang, B.-G. Bisthiodiketopiperazines and Acorane Sesquiterpenes Produced by the Marine-Derived Fungus Penicillium adametzioides AS-53 on Different Culture Media. J. Nat. Prod. 2015, 78, 1294-1299. [CrossRef]

246. Liu, Y.; Mandi, A.; Li, X.M.; Meng, L.H.; Kurtan, T.; Wang, B.G. Peniciadametizine A, a Dithiodiketopiperazine with a Unique Spiro[furan-2,7'-pyrazino[1,2-b] [1,2] oxazine] Skeleton, and a Related Analogue, Peniciadametizine B, from the Marine Sponge-Derived Fungus Penicillium adametzioides. Mar. Drugs 2015, 13, 3640-3652. [CrossRef]

247. Ma, X.; Zhu, T.; Gu, Q.; Xi, R.; Wang, W.; Li, D. Structures and antiviral activities of butyrolactone derivatives isolated from Aspergillus terreus MXH-23. J. Ocean U. China 2014, 13, 1067-1070. [CrossRef]

248. Qin, C.; Lin, X.; Lu, X.; Wan, J.; Zhou, X.; Liao, S.; Tu, Z.; Xu, S.; Liu, Y. Sesquiterpenoids and xanthones derivatives produced by sponge-derived fungus Stachybotry sp. HH1 ZSDS1F1-2. J. Antibiot. 2014, 68, 121-125. [CrossRef]

249. Sato, S.; Iwata, F.; Fukae, T.; Katayama, M. Neomacquarimicin: A new macquarimicin analog from marine-derived actinomycete. J. Antibiot. 2014, 67, 479-482. [CrossRef]

250. Wang, J.-F.; Lin, X.-P.; Qin, C.; Liao, S.-R.; Wan, J.-T.; Zhang, T.-Y.; Liu, J.; Fredimoses, M.; Chen, H.; Yang, B.; et al. Antimicrobial and antiviral sesquiterpenoids from sponge-associated fungus, Aspergillus sydowii ZSDS1-F6. J. Antibiot. 2014, 67, 581-583. [CrossRef]

251. Wang, J.-F.; Xu, F.-Q.; Wang, Z.; Lu, X.; Wan, J.-T.; Yang, B.; Zhou, X.-F.; Zhang, T.-Y.; Tu, Z.-C.; Liu, Y. A new naphthalene glycoside from the sponge-derived fungus Arthrinium sp. ZSDS1-F3. Nat. Prod. Res. 2014, 28, 1070-1074. [CrossRef]

252. Yi-Lei, N.; Yun-Dan, W.; Chuan-Xi, W.; Ru, L.; Yang, X.; Dong-Sheng, F.; Hong, J.; Yun-Yang, L. Compounds from marine-derived Verrucosispora sp. FIM06054 and their potential antitumour activities. Nat. Prod. Res. 2014, 28, 2134-2139. [CrossRef] [PubMed]

253. Kong, F.; Zhao, C.; Hao, J.; Wang, C.; Wang, W.; Huang, X.; Zhu, W. New $\alpha$-glucosidase inhibitors from a marine sponge-derived fungus, Aspergillus sp. OUCMDZ-1583. RSC Adv. 2015, 5, 68852-68863. [CrossRef]

254. Li, L.; Zhang, Y.; Li, Z.; Yu, Z.; Sun, T. Stereochemical investigation of a novel biological active substance from the secondary metabolites of marine fungus Penicillium chrysogenum SYP-F-2720. J. Mex. Chem. Soc. 2015, 59, 53-58.

255. Ngokpol, S.; Suwakulsiri, W.; Sureram, S.; Lirdprapamongkol, K.; Aree, T.; Wiyakrutta, S.; Mahidol, C.; Ruchirawat, S.; Kittakoop, P. Drimane Sesquiterpene-Conjugated Amino Acids from a Marine Isolate of the Fungus Talaromyces minioluteus (Penicillium minioluteum). Mar. Drugs 2015, 13, 3567-3580. [CrossRef] [PubMed]

256. Prompanya, C.; Fernandes, C.; Cravo, S.; Pinto, M.; Dethoup, T.; Silva, A.; Kijjoa, A. A New Cyclic Hexapeptide and a New Isocoumarin Derivative from the Marine Sponge-Associated Fungus Aspergillus similanensis KUFA 0013. Mar. Drugs 2015, 13, 1432-1450. [CrossRef]

257. Zhao, D.-L.; Shao, C.-L.; Gan, L.-S.; Wang, M.; Wang, C.-Y. Chromone Derivatives from a Sponge-Derived Strain of the Fungus Corynespora cassiicola. J. Nat. Prod. 2015, 78, 286-293. [CrossRef]

258. Zhao, D.-L.; Shao, C.-L.; Wang, C.-Y.; Wang, M.; Yang, L.-J.; Wang, C.-Y. Naphthalenones and Depsidones from a Sponge-Derived Strain of the Fungus Corynespora cassiicola. Molecules 2016, 21, 160. [CrossRef]

259. Che, Q.; Tan, H.; Han, X.; Zhang, X.; Gu, Q.; Zhu, T.; Li, D. Naquihexcin A, a S-Bridged Pyranonaphthoquinone Dimer Bearing an Unsaturated Hexuronic Acid Moiety from a Sponge-Derived Streptomyces sp. HDN-10-293. Org. Lett. 2016, 18, 3358-3361. [CrossRef]

260. Igarashi, Y.; Asano, D.; Sawamura, M.; In, Y.; Ishida, T.; Imoto, M. Ulbactins F and G, Polycyclic Thiazoline Derivatives with Tumor Cell Migration Inhibitory Activity from Brevibacillus sp. Org. Lett. 2016, 18, 1658-1661. [CrossRef]

261. Peng, J.; Zhang, X.; Wang, W.; Zhu, T.; Gu, Q.; Li, D. Austalides S-U, New Meroterpenoids from the Sponge-Derived Fungus Aspergillus aureolatus HDN14-107. Mar. Drugs 2016, 14, 131. [CrossRef] 
262. Sekurova, O.; Pérez-Victoria, I.; Martín, J.; Degnes, K.; Sletta, H.; Reyes, F.; Zotchev, S. New Deferoxamine Glycoconjugates Produced upon Overexpression of Pathway-Specific Regulatory Gene in the Marine Sponge-Derived Streptomyces albus PVA94-07. Molecules 2016, 21, 1131. [CrossRef] [PubMed]

263. Wang, Y.; Lin, X.-P.; Ju, Z.-R.; Liao, X.-J.; Huang, X.-J.; Zhang, C.; Zhao, B.-X.; Xu, S.-H. Aspergchromones A and $\mathrm{B}$, two new polyketides from the marine sponge-associated fungus Aspergillus sp. SCSIO XWS03F03. J. Asian Nat. Prod. Res. 2017, 19, 684-690. [CrossRef] [PubMed]

(C) 2020 by the authors. Licensee MDPI, Basel, Switzerland. This article is an open access article distributed under the terms and conditions of the Creative Commons Attribution (CC BY) license (http://creativecommons.org/licenses/by/4.0/). 